Aus dem Institut für Humangenetik

(Prof. Dr. med. B. Wollnik)

im Zentrum Hygiene und Humangenetik

der Medizinischen Fakultät der Universität Göttingen

\title{
Haplotypanalyse bei Familien mit einem Kind mit CHARGE- Syndrom und Kandidatengenscreening CHD8 und FAM124B
}

\author{
INAUGURAL-DISSERTATION \\ zur Erlangung des Doktorgrades \\ der Medizinischen Fakultät \\ der Georg-August-Universität zu Göttingen \\ vorgelegt von \\ Nina von Velsen
}

aus Ibbenbüren

Göttingen 2017 
Dekan:

I. Berichterstatter:

II. Berichterstatter:

Tag der mündlichen Prüfung:
Prof. Dr. rer. nat. H. K. Kroemer

Frau PD Dr. med. S. J. Pauli

Herr PD Dr. med. M. Henneke 


\section{Inhalt}

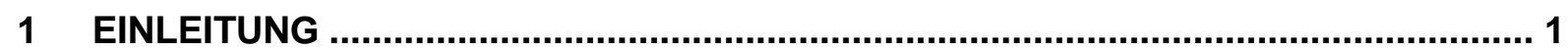

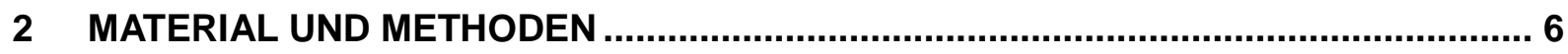

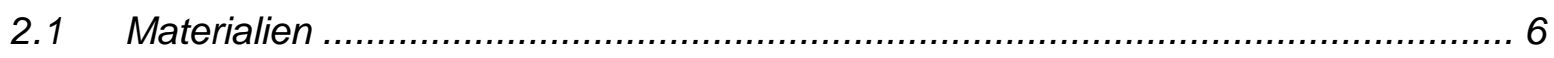

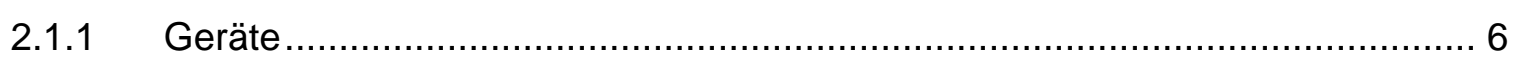

2.1.2 Verbrauchsmaterialien ...................................................................... 7

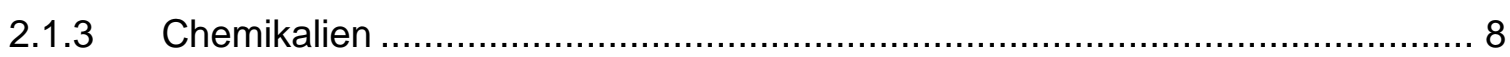

2.1.4 Stammlösungen, Puffer, Medien .............................................................. 10

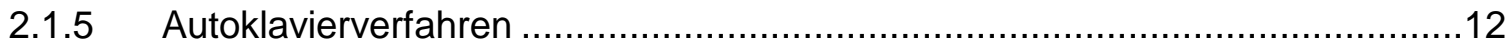

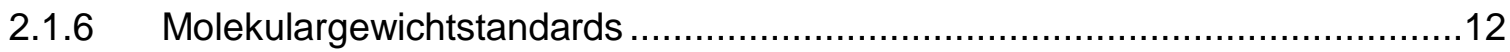

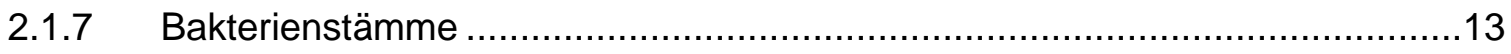

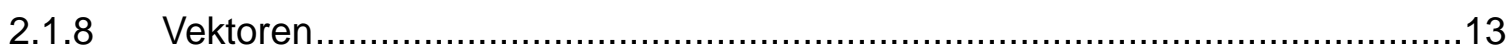

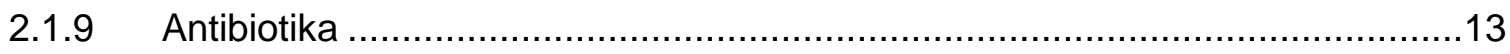

2.1.10 OYA-Platten/Ampicillin-IPTG/X-Gal-Plattten ........................................... 13

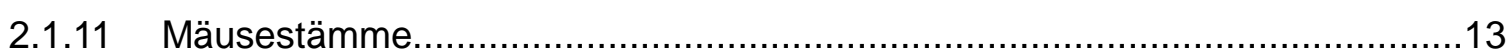

2.1.12 Organe und Gewebeproben ................................................................. 13

2.1.13 Synthetische Oligonukleotide …........................................................ 14

2.1.13.1 Oligonukleotide für die Amplifikation und Sequenzierung des Kandidatengens CHD8............................................................ 14

2.1.13.2 Oligonukleotide für die Amplifizierung und Sequenzierung des Kandidatengens FAM124B..........................................................17

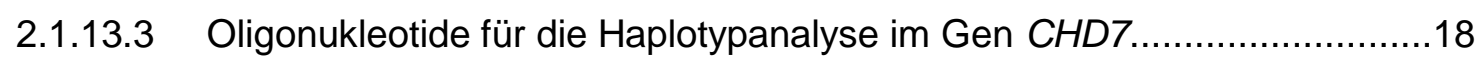

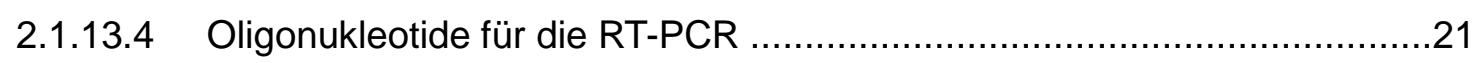

2.1.13.5 Oligonukleotide für die Amplifizierung der DNA und die Yq11-PCR..........22

2.1.14 Datenbanken und Computeranalysen ...................................................23

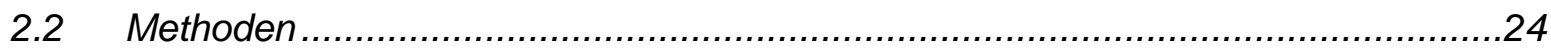

2.2.1 Isolierung genomischer DNA aus peripherem Blut ...................................24

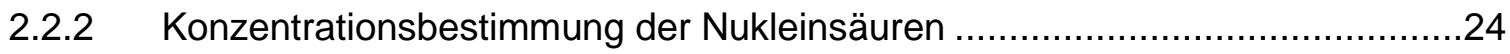

2.2.3 Isolierung von Gesamt-RNA aus peripherem Blut (PEQLAB Total RNA Kit) ....25

2.2.4 Isolierung von Gesamt-RNA aus Mausgeweben ..........................................25

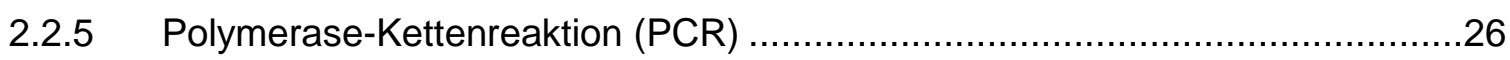

2.2.6 PCR an genomischer DNA zur Abklärung aussagekräftiger Polymorphismen .26

2.2.7 PCR an genomischer DNA nach Auffinden eines aussagekräftigen Polymorphismus 
2.2.7.1 Amplifizierung mit HotStar HiFidelity-DNA-Polymerase ..........................28

2.2.7.2 Amplifizierung mit Phusion High-Fidelity DNA-Polymerase ......................28

2.2.7.3 Amplifizierung mit peqGOLD Pwo-DNA-Polymerase ................................29

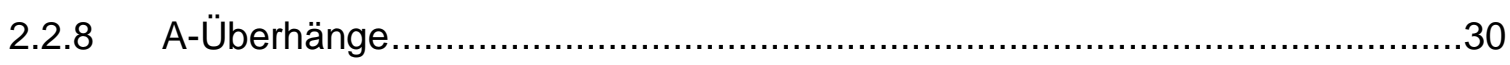

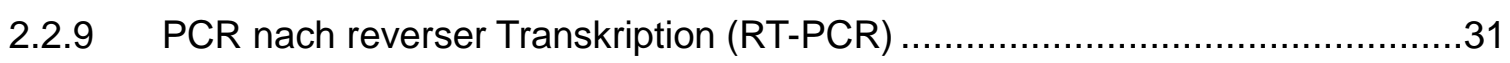

2.2.10 Restriktionsanalyse von DNA ............................................................... 31

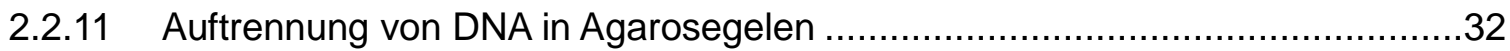

2.2.12 Isolierung von DNA-Fragmenten aus Agarosegelen ....................................

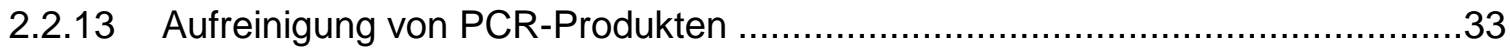

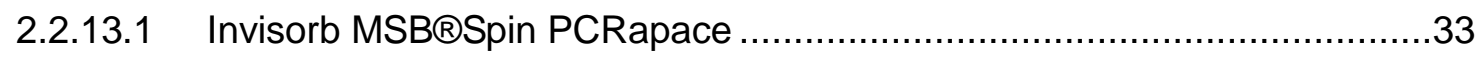

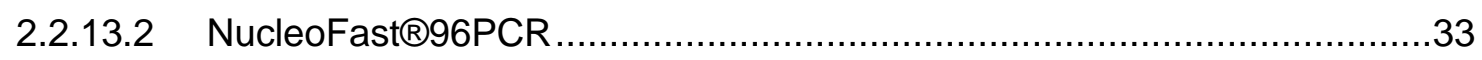

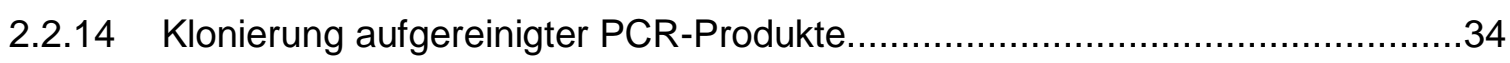

2.2.15 Transformation von Plasmiden in E. coli-DH5a-Zellen....................................34

2.2.16 Isolierung von Plasmid-DNA mithilfe von Minipräparation................................35

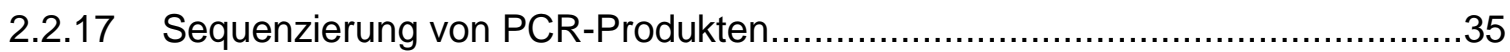

2.2.18 Aufreinigung von Sequenzierprodukten für den Megabace-Sequenzierer .......36

2.2.19 Mikrosatellitenanalyse zur Überprüfung der Familientriplets ..........................37

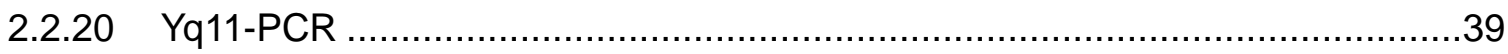

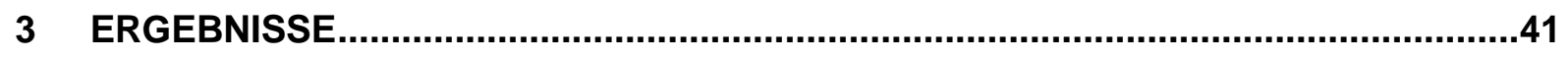

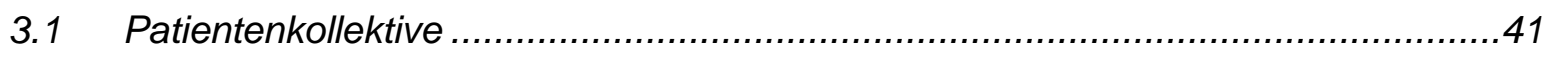

3.2 Patientenkollektive für Kandidatengenscreening ............................................41

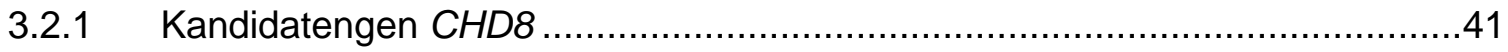

3.2.2 Kandidatengen FAM124B.......................................................................

3.3 Patientenkollektiv für Haplotypanalyse ....................................................48

3.3.1 Familien mit informativen Polymorphismen .............................................49

3.3.1.1 Familien mit nicht eindeutiger Zuordnung ...........................................65

3.3.2 Familien mit nicht aussagekräftigem Polymorphismus ................................72

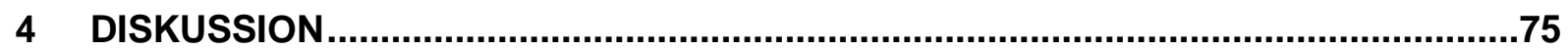

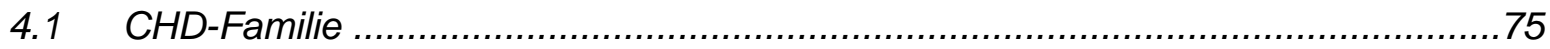

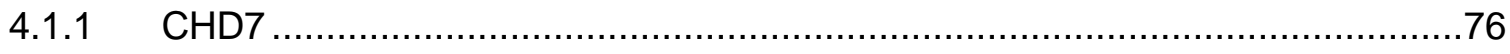

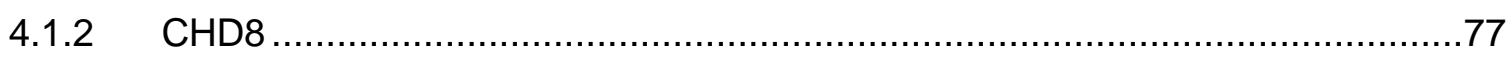

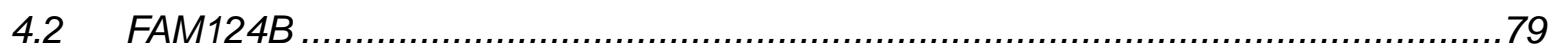

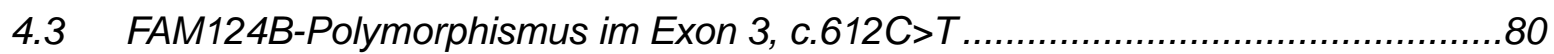

$4.4 \quad$ Ursachen für die Entstehung von Neumutationen.......................................80 


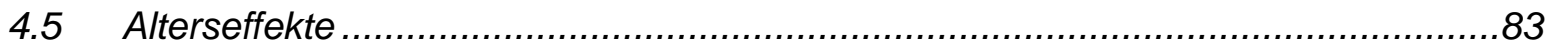

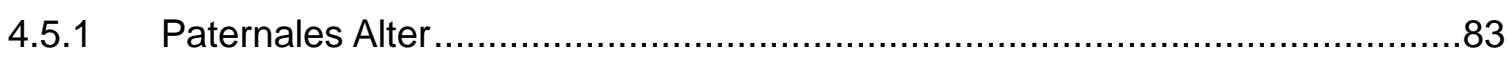

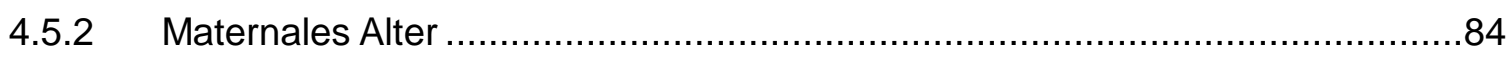

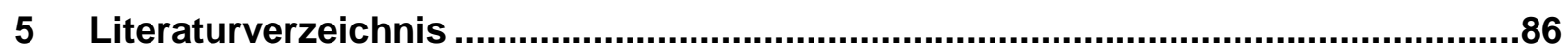




\section{Abkürzungsverzeichnis:}

\begin{tabular}{|c|c|}
\hline A & Ampère \\
\hline $\mathrm{Bp}$ & Basenpaare \\
\hline${ }^{\circ} \mathrm{C}$ & Grad Celsius \\
\hline cDNA & komplementäre Desoxyribonukleinsäure \\
\hline CHD & chromodomain-helicase-DNA binding protein \\
\hline del & Deletion \\
\hline ddNTP & Didesoxynukleosidtriphosphat \\
\hline $\mathrm{dH}_{2} \mathrm{O}$ & destilliertes Wasser \\
\hline DNA & Desoxyribonukleinsäure \\
\hline dNTP & Desoxynukleosidtriphosphat \\
\hline dup & Duplikation \\
\hline E.coli & Escherichia coli \\
\hline EDTA & Ethylendiamintetraessigsäure \\
\hline et al. & et alii (und andere) \\
\hline $\mathrm{EtOH}$ & Ethanol \\
\hline FGFR & fibroblast growth factor receptor \\
\hline g & Gramm; Erdbeschleunigung \\
\hline GAPDH & Glycerinaldehydphosphatdehydrogenase \\
\hline $\mathrm{h}$ & Stunde \\
\hline $\mathrm{H}_{2} \mathrm{O}$ & Wasser \\
\hline IPTG & Isopropyl-beta-D-thiogalactopyranosid \\
\hline $\mathrm{k}$ & Kilo $\left(10^{3}\right)$ \\
\hline $\mathrm{Kb}$ & Kilobasen \\
\hline $\mathrm{KHCO}_{3}$ & Kaliumhydrogencarbonat \\
\hline I & Liter \\
\hline lacZ-Gen & Beta Galaktosidase Lactase-kodierendes Gen von E.coli \\
\hline LB & Lysogeny broth \\
\hline $\mathrm{m}$ & Meter; Milli $\left(10^{-3}\right)$ \\
\hline$\mu$ & Mikro $\left(10^{-6}\right)$ \\
\hline M & Molar \\
\hline MDTT & 1-Methyl-1,4-dihydro-5H-tetrazole-5-thione \\
\hline
\end{tabular}




\begin{tabular}{|c|c|}
\hline $\mathrm{MgCl}_{2}$ & Magnesiumchlorid \\
\hline $\min$ & Minute \\
\hline MLPA & muliplex ligation-dependent probe amplification \\
\hline mRNA & messenger ribonucleic acid \\
\hline$n$ & Nano $\left(10^{-9}\right)$ \\
\hline N. & Nervus \\
\hline $\mathrm{NaCl}$ & Natriumchlorid \\
\hline $\mathrm{NaOH}$ & Natriumhydroxid \\
\hline $\mathrm{NH}_{4} \mathrm{Cl}$ & Ammoniumchlorid \\
\hline $\mathrm{Na}_{2} \mathrm{HPO}_{4}$ & Dinatriumhydrogenphosphat \\
\hline $\mathrm{NaH}_{2} \mathrm{PO}_{4}$ & Natriumdihydrogenphosphat \\
\hline o. g. & oben genannt \\
\hline $\mathrm{Pa}$ & Pascal \\
\hline p. c. & post conceptionem \\
\hline PCR & Polymerase-Kettenreaktion \\
\hline PTPN 11 & Protein Tyrosine Phosphatase Non-Receptor Type 11 \\
\hline $\mathrm{RT}$ & Raumtemperatur \\
\hline RNAse & Ribonuklease \\
\hline RT-PCR & Reverse Transkriptase-Polymerase-Kettenreaktion \\
\hline s. & siehe \\
\hline SDS & Natriumlaurylsulfat \\
\hline sec & Sekunde \\
\hline SE & Saline-EDTA-Puffer \\
\hline Seq & Sequenzierprimer \\
\hline SNP & single nucleotid polymorphism \\
\hline S.O.C. & Medium zur Anzucht von E.coli \\
\hline SSC & standard sodium citrate \\
\hline Taq & Thermus aquaticus \\
\hline TBE & Tris-Borat-EDTA \\
\hline TE & Tris-EDTA \\
\hline Tris & Trishydroxymethylaminomethan \\
\hline u. a. & unter anderem \\
\hline
\end{tabular}


$U$

unit= definierte Enzymeinheit

UV ultraviolett

ü. N. über Nacht

V Volt

V. a. Verdacht auf

v. a. $\quad$ vor allem

Vol Volumen

$\mathrm{w} / \mathrm{v} \quad$ weight per volume

X-Gal 5-Brom-4-Chlor-3-Indolyl-beta-D-Galaktopyranosid

\section{Code der Aminosäuren}
A Ala Alanin
C Cys Cystein
D Asn Asparaginsäure
E Glu Glutaminsäure
F Phe Phenylalanin
G Gly Glycin
$\mathrm{H} \quad$ His Histidin
I Ile Isoleucin
$\mathrm{K}$ Lys Lysin
L Leu Leucin
M Met Methionin
$\mathrm{N}$ Asn Asparagin 
P Pro Prolin

Q Gln Glutamin

R Arg Arginin

$\mathrm{S}$ Ser Serin

T Thr Threonin

V Val Valin

W Trp Tryptophan

Y Tyr Tyrosin

\section{Code der Nukleinsäuren}
A Adenin
C Cytosin
G Guanin
$\mathrm{T} \quad$ Thymin
U Uracil 


\section{Abbildungsverzeichnis:}

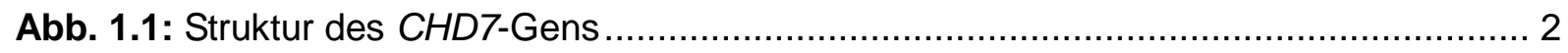

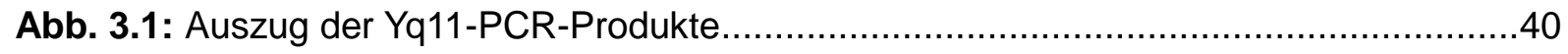

Abb. 3.2: CHD8-Screening-Auszug eines 1\%igen Agarosegels ......................................42

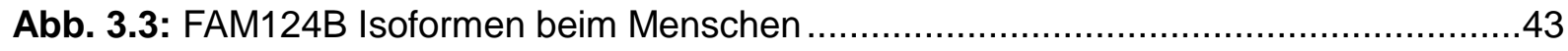

Abb. 3.4: RT-PCR-Produkte von Fam124B bei der Maus ..................................................44

Abb. 3.5: Sequenzdarstellung des Produktes FAM124B Ex.3.1 .....................................45

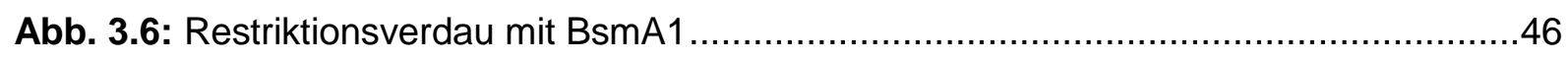

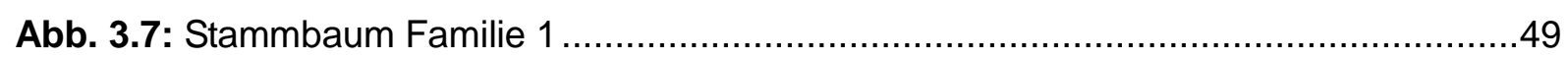

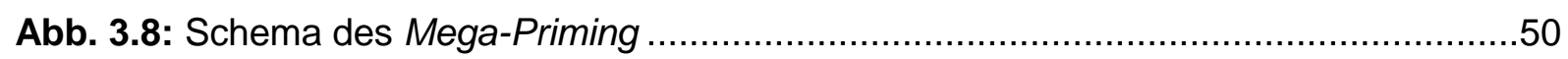

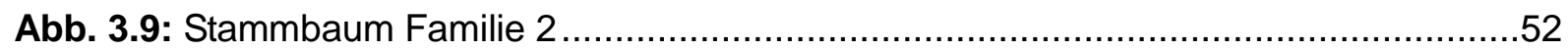

Abb. 3.10: Sequenzauszug mit dem Primer SNP CHD7 E28I28F der väterlichen DNA .......53

Abb. 3.11: Grafische Darstellung der Allelzuordung in Familie 2 ......................................53

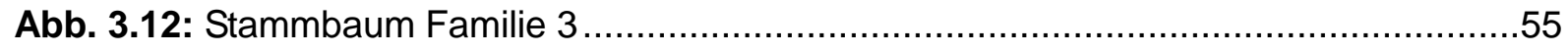

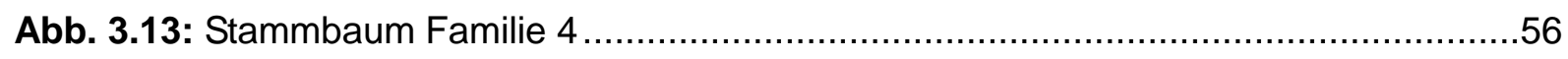

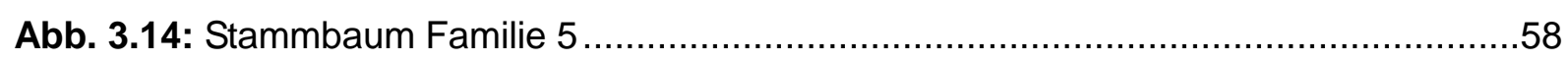

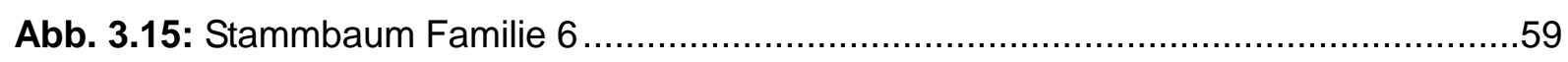

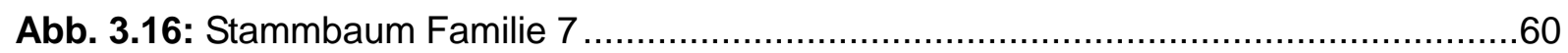

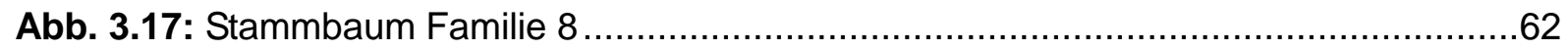

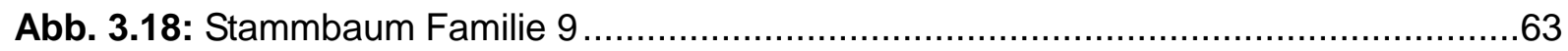

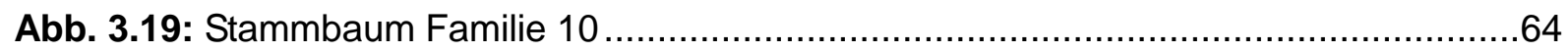

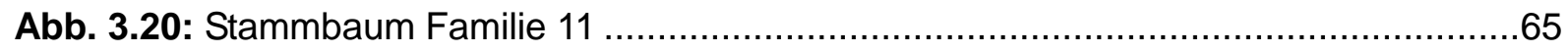

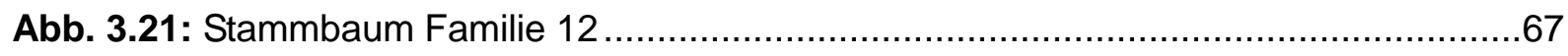

Abb. 3.22: PCR-Produkte einer RT-PCR auf einem Agarosegel 1 \% ...............................69

Abb. 3.23: Stammbaum Familie 13 .................................................................. 
Tabellenverzeichnis:

Tab. 1.1: Klinisch-diagnostische Kriterien für das CHARGE-Syndrom nach Blake et al. (1998) und Verloes (2005)

Tab. 1.2: Häufigkeit der verschiedenen Mutationen in Prozent bei 528 CHD7-positiven Patienten

Tab. 3.1: Ergebnis der Sequenzierung der Colony-PCR-Produkte der Patientin der Familie 1

Tab. 3.2: Ergebnisse der Sequenzierung der Colony-PCR-Produkte der Patientin 1 51

Tab. 3.3: Auswertung der Sequenzen der Colony-PCR-Produkte der Patientin 2. .54

Tab. 3.4: Ergebnis der Sequenzierung der Colony-PCR-Produkte des Patienten 3..............55

Tab. 3.5: Ergebnis der Sequenzierung der Colony-PCR-Produkte des Patienten 4 .56

Tab. 3.6: Ergebnis der Sequenzierung der Colony-PCR-Produkte des Patienten 4.

Ausgangsprodukt: HotStar HiFidelity-DNA-Polymerase.

Tab. 3.7: Ergebnis der Sequenzierung der Colony-PCR-Produkte des Patienten 4.

Ausgangsprodukt: peqGOLD Pwo-DNA-Polymerase .57

Tab. 3.8: Ergebnis der Sequenzierung der Colony-PCR-Produkte des Patienten 5 .58

Tab. 3.9: Ergebnis der Sequenzierung der Colony-PCR-Produkte des Patienten 6 .59

Tab. 3.10: Ergebnis der Sequenzierung der Colony-PCR-Produkte des Patienten 7 .60

Tab. 3.11: Ergebnis der Sequenzierung der Colony-PCR-Produkte des Patienten 7.

Ausgangs-PCR-Produkt: peqGOLD Pwo-DNA-Polymerase

Tab. 3.12: Ergebnis der Sequenzierung der Colony-PCR-Produkte des Patienten $8 \ldots \ldots \ldots . . . .62$

Tab. 3.13: Ergebnis der Sequenzierung der Colony-PCR-Produkte des Patienten 9...........63

Tab. 3.14: Ergebnis der Sequenzierung der Colony-PCR-Produkte des Patienten 10.........64

Tab. 3.15: Ergebnis der Sequenzierung der Colony-PCR-Produkte des Patienten 11 .........66

Tab. 3.16: Ergebnis der Sequenzierung der Colony-PCR-Produkte des neuen PCR-

Produktes des Patienten 11 .66

Tab. 3.17: Ergebnis der Sequenzierung der Colony-PCR-Produkte des Patienten 12

Tab. 3.18: Ergebnis der Sequenzierung der Colony-PCR-Produkte mit der peqGOLD PwoDNA-Polymerase des Patienten 12.

Tab. 3.19: Ergebnis der Sequenzierung der Colony-PCR des Patienten 13

Tab. 3.20: Ergebnis der Sequenzierung der Colony-PCR-Produkte des 2. PCR-Produktes

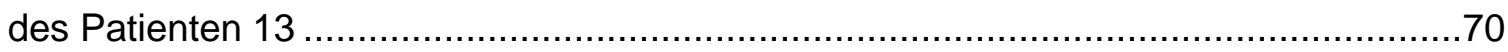

Tab. 3.21: Auflistung der untersuchten Polymorphismen in den übrigen 17 Familien

Tab. 4.1: Auswahl von autosomal dominant und X-chromosomal vererbten Krankheitsbildern 


\section{EINLEITUNG}

Beim CHARGE-Syndrom handelt es sich um ein autosomal dominantes Dysmorphiesyndrom, das erstmals 1979 durch Hall und Hittner beschrieben wurde (Hall 1979, Hittner et al. 1979). Der Begriff CHARGE wurde 1981 durch Pagon et al. geprägt und stellt ein Akronym für die Hauptsymptome dieser Erkrankung dar: Kolobome (engl.: coloboma), Herzfehler, Atresie der Choanen, Retardierung des Wachstums und der psychomotorischen Entwicklung, Genitalhypoplasien und Ohranomalien (engl.: ear anomalies), insbesondere Innenohrschwerhörigkeit. Weiterhin werden zahlreiche andere Fehlbildungen wie Lippen-Kiefer-Gaumenspalten, Bogengangskanalaplasien, Fazialisparesen, tracheo-ösophageale Fisteln oder Fehlbildungen des Urogenitaltraktes bei den Patienten beobachtet (Lalani et al. 2006, Jongmans et al. 2006, Zentner et al. 2010, Bergman et al. 2011). Aufgrund dieser vielfältigen Symptome lässt sich die große Variabilität im klinischen Phänotyp erkennen, welche die klinische Diagnosestellung erschwert. Deshalb wurden die genannten Symptome in Haupt- und Nebenkriterien eingeteilt (Blake et al.1998), die durch Verloes (2005) überarbeitet wurden (s. Tabelle 1.1).

\begin{tabular}{|c|c|}
\hline \multicolumn{2}{|l|}{ Hauptkriterien } \\
\hline nach Blake et al. 1998 & nach Verloes 2005 \\
\hline Kolobome mit/ ohne Mikroophthalmie & Kolobome mit/ ohne Mikroophthalmie \\
\hline Choanalatresie & Choanalatresie \\
\hline \multicolumn{2}{|l|}{ Dysfunktion einzelner Hirnnerven (VII-XII) } \\
\hline $\begin{array}{l}\text { Charakteristische Anomalien des Innenohrs } \\
\text { und des äußeren Ohrs }\end{array}$ & Hypoplastische Bogengänge \\
\hline \multicolumn{2}{|l|}{ Nebenkriterien } \\
\hline nach Blake et al. 1998 & nach Verloes 2005 \\
\hline Dysmorphien des Gesichts & $\begin{array}{l}\text { Dysfunktion des Rhombenzephalons } \\
\text { (Hirnstammdysfunktion, neurosensorische } \\
\text { Schwerhörigkeit, Lähmungen der Hirnner- } \\
\text { ven VII-XII) }\end{array}$ \\
\hline Kardiovaskuläre Fehlbildungen & $\begin{array}{l}\text { Anomalien des Herzens, Ösophagusfehlbil- } \\
\text { dungen }\end{array}$ \\
\hline Tracheo-ösophageale Fisteln & Hypothalamo-hypophysäre Fehlfunktionen \\
\hline Wachstumsretardierung & Anomalien des äußeren Ohrs/ Mittelohrs \\
\hline
\end{tabular}




\begin{tabular}{|l|l|}
\hline \multicolumn{2}{|l|}{ Nebenkriterien } \\
\hline nach Blake et al. 1998 & nach Verloes 2005 \\
\hline $\begin{array}{l}\text { Genitalhypoplasie, verzögerte und } \\
\text { unvollständige Pubertät }\end{array}$ & Geistige Behinderung \\
\hline Lippen-Kiefer-Gaumen-Spalte & \\
\hline $\begin{array}{l}\text { Psychomotorische } \\
\text { Entwicklungsretardierung }\end{array}$ & \\
\hline Hypotonie & \\
\hline
\end{tabular}

Tab.1.1: Klinisch-diagnostische Kriterien für das CHARGE-Syndrom nach Blake et al. (1998) und Verloes (2005): Ein klassisches CHARGE-Syndrom liegt vor, wenn drei Hauptkriterien oder zwei Hauptkriterien mit mindestens zwei Nebenkriterien vorliegen. Wenn zwei Hauptkriterien mit einem Nebenkriterium bestehen, spricht man von einem partiellen CHARGE-Syndrom. Ein atypisches CHARGE-Syndrom liegt bei Vorhandensein von zwei Hauptkriterien oder einem Hauptkriterium mit zwei Nebenkriterien vor.

Ursächlich für das CHARGE-Syndrom sind Mutationen im CHD7-Gen, das auf dem Chromosom 8q12.1 lokalisiert ist (Vissers et al. 2004). Das Gen besteht aus 38 Exons und kodiert für ein 2997 Aminosäuren umfassendes Protein. Es gehört zu der Familie der CHDGene, welche für Proteine kodieren, die unter Energieverbrauch den Histon-DNA-Kontakt in Nukleosomen verändern und folglich eine Konformationsänderung des Chromatins bewirken können (Becker und Hörz 2002). Das CHD7-Gen ist gekennzeichnet durch das Vorhandensein von zwei N-terminalen Chromodomänen, einer SWI2/SNF2-ähnlichen ATPase/Helicase, drei konservierten Regionen (CR1-3), einer SANT-Domäne und zwei BRK-Domänen (Flaus et al. 2006) (s. Abbildung 1.1).

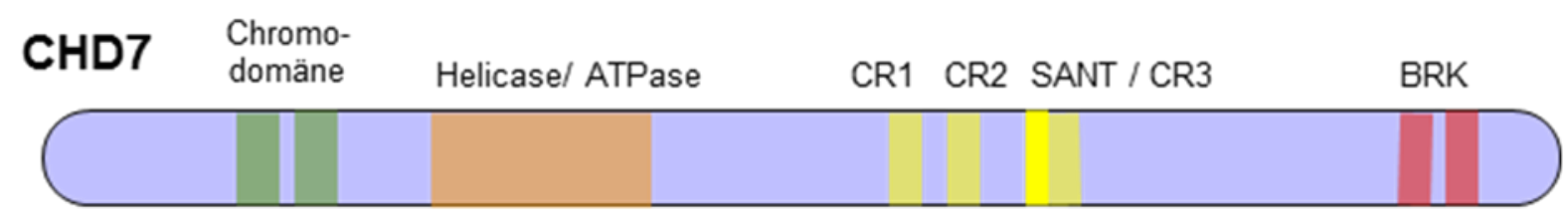

Abb.1.1: Struktur des CHD7-Gens: Es umfasst zwei N-terminale Chromodomänen, eine SWI2/ SNF2 ähnliche ATPase/Helicase, drei konservierte Regionen [CR1, CR2, CR3], eine SANT-Domäne und 
zwei BRK-Domänen (Flaus et al. 2006). (Abb. modifiziert nach Pauli 2010, S. 22. Die Verwendung des Bildes erfolgt mit freundlicher Genehmigung des Median-Verlags.)

Durch die Veränderungen der Chromatinstruktur können wichtige Prozesse im Organismus wie Transkriptionsregulation, DNA-Reparaturmechanismen oder die Replikation beeinflusst werden. Dabei sind die genauen Funktionen des CHD7, das ausschließlich im Zellkern nachweisbar ist (Schnetz et al. 2009), noch nicht hinreichend untersucht worden. Anhand der Domänenarchitektur und unter Berücksichtigung der Ergebnisse bei Knockout-Mäusen kann vermutet werden, dass diesem Protein eine entscheidende Bedeutung in der Entwicklung des Embryos und der Zellzyklusregulation zugeschrieben werden kann (Bosman et al. 2005, Schnetz et al. 2009). Beim Menschen wird CHD7 bis zum 22. Tag p. c. ubiquitär exprimiert. In späteren Entwicklungsperioden findet man eine CHD7-Expression in Geweben, wie z. B. in Auge und Ohr, die vom CHARGE-Syndrom betroffen sind. Diese Ergebnisse beruhen auf Untersuchungen an elektiv abortierten menschlichen Embryonen (Sanlaville et al. 2006). Ein Großteil der im CHD7-Gen beschriebenen Mutationen sind Nonsense- oder FrameshiftMutationen, aber auch von Splice-site- und Missense-Mutationen wird in der Literatur berichtet (vgl. Tabelle 1.2). Die Mutationen sind über den gesamten kodierenden Bereich des Gens verteilt, sodass keine sog. hot spots ermittelt werden können.

\begin{tabular}{|ll|}
\hline Mutationstyp & Frequenz (\%) \\
\hline Nonsense & 44 \\
\hline Frameshift & 34 \\
\hline Missense & 8 \\
\hline Splice-site & 11 \\
\hline Inframe Deletion & $<1$ \\
\hline Deletion/ Duplikation & 2 \\
\hline Translokation & $<1$ \\
\hline
\end{tabular}

Tab.1.2: Häufigkeit der verschiedenen Mutationen in Prozent bei 528 CHD7-positiven Patienten, zusammengefasst aus verschiedenen Studien durch Janssen et al. (2012).

Bei ca. 2/3 der Patienten mit der klinischen Diagnose CHARGE-Syndrom findet sich eine Mutation im CHD7-Gen. Bei den Patienten ohne Mutation im kodierenden Bereich sind 
Mutationen im nicht-translatierten Bereich, in regulatorischen Elementen oder in anderen bisher nicht bekannten Genen denkbar.

Aufgrund von Literaturdaten kann vermutet werden, dass CHD7 Bestandteil eines großen Chromatin-remodelling-Komplexes ist. So wurde in der Arbeitsgruppe bei der Suche nach möglichen Interaktionspartnern des CHD7-Proteins in einem yeast two hybrid library screen CHD8 als putativer Interaktionspartner detektiert (vgl. Batsukh et al. 2010).

CHD8 gehört ebenfalls zur Familie der CHD-Gene und liegt auf dem Chromosom 14q11.2. Im Rahmen der Forschungsarbeit unserer Arbeitsgruppe wurde zusätzlich das Gen FAM124B entdeckt, welches eventuell als ein Ankerprotein zwischen CHD7 und CHD8 fungiert (Batsukh et al. 2012). Zu FAM124B gibt es bisher keine Publikationen über die möglichen Funktionen im Organismus.

Die Inzidenz des CHARGE-Syndroms wird derzeit auf 1: 8500 geschätzt (Issekutz et al. 2005). Die meisten Fälle treten sporadisch auf. Allerdings wird in der Literatur über einige wenige familiär auftretende Fälle berichtet. Entweder konnte dabei ein somatisches Mosaik bei einem der Elternteile gefunden werden (Jongmans et al. 2006 und 2008, Bartels et al. 2010, Janssen et al. 2012) oder es wurden Gonadenmosaike postuliert (Lanani et al. 2006, Jongmans et al. 2008) oder ein Gonadenmosaik konnte in den Spermien des Vaters nachgewiesen werden (Pauli et al. 2009). Systematische Studien hinsichtlich der Rate an Gonadenmosaiken sind bisher beim CHARGE-Syndrom nicht durchgeführt worden. Die Rate an Gonadenmosaiken wird gegenwärtig auf ca. $3 \%$ geschätzt (Jongmans et al. 2008). Ebenfalls wird postuliert, dass das Auftreten eines CHARGE-Syndroms mit einem erhöhten väterlichen Zeugungsalter assoziiert ist (Tellier et al. 1996). Angaben, ob das mütterliche oder väterliche Allel bevorzugt von einer CHD7-Neumutation betroffen ist und ob CHD7Mutationen mit einem erhöhten väterlichen Alter zu sehen sind, waren zum damaligen Zeitpunkt nicht möglich. Eine CHD7-Mutationsanalytik und somit ein molekulargenetischer Nachweis, dass es sich bei den Symptomen des Betroffenen in der Tat um ein CHARGESyndrom handelt, war nicht verfügbar.

Bei vielen weiteren autosomal dominant vererbten Krankheiten wie der Tuberösen Sklerose, Neurofibromatose 2, Keratitis-Ichothyosis-Taubheitssyndrom, Campomelie-Dysplasie, Ehlers-Danlos-Syndrom oder Timothy-Syndrom wurde in Einzelfällen das Vorhandensein von Gonadenmosaiken beschrieben, jedoch ist hier eine allgemein einheitliche Zuordnung zum maternalen oder paternalen Allel nicht möglich (vgl. Cameron et al. 1996, Splawski et al. 2004, Mazereeuw-Hautier et al. 2007). Bisher sind keine Erkrankungen bekannt, bei denen eine de novo-Mutation ausschließlich das maternale Allel betrifft. 
Sollte es sich beim CHARGE-Syndrom um eine Erkrankung handeln, bei der die Mutationen in der männlichen Keimbahn entstehen, so kann im Rahmen einer weiteren Studie systematisch die Rate an Gonadenmosaiken bestimmt werden, indem bei Vätern mit einem betroffenen Kind eine Spermienanalyse durchgeführt wird.

Somit ergaben sich im Rahmen der vorliegenden Arbeit zwei verschiedene Aufgabenstellungen:

Bei 30 Patienten mit einer Mutation im CHD7-Gen wurde eine Haplotypbestimmung durchgeführt, um festzustellen, ob die jeweilige Neumutation beim CHARGE-Patienten maternalen oder paternalen Ursprungs ist und ob das Auftreten einer CHD7-Mutation mit einem erhöhten väterlichen Zeugungsalter einhergeht.

Die Kandidatengene CHD8 und FAM124B wurden bei Patienten mit der klinisch gestellten Diagnose CHARGE-Syndrom, aber ohne Mutationsnachweis im CHD7-Gen, mithilfe einer Sequenzanalyse auf Punktmutationen untersucht. 


\section{MATERIAL UND METHODEN}

Alle Chemikalien, die nachfolgend nicht gesondert aufgeführt sind, wurden von der Firma Merck (Darmstadt) bezogen. Alle molekularbiologischen Standardmethoden, die nicht dargestellt sind, wurden nach den Angaben von Sambrook et al. (1989) durchgeführt.

\subsection{Materialien}

\subsubsection{Geräte}

$\mathrm{ABI}$ genetic Analyzer 3130

Abzug Captair® 4000NU

Acht-Kanal-Pipette

Bio Photometer

Dampfdruckautoklav

Dispergierwerkzeug Ultraturrax T25

Horizontale Mini Gel-Kammer

Horizontales Gel-Elektrophorese-

System Horizon ${ }^{\mathrm{TM}} 11.14$

Kühlzentrifuge 5417R

Multipipette Multipipette® plus

$(10-100 \mu l)$

Pipetman-Pipetten

$(10,20,100,200,1000 \mu l)$

Primus 25 advanced( $\AA$ Thermal Cycler

Photogerät E.A.S.Y. RH3

PTC-100 ${ }^{\mathrm{TM}}$ Thermal Cycler

Rüttler IKA-Vibrax-VXR
Invitrogen, Karlsruhe

Erlab, Pont de L’'Arche, Frankreich

Eppendorf, Hamburg

Eppendorf, Hamburg

Webeco, Bad Schwartau

Schütt, Göttingen

Medizintechnik, Universität Göttingen

BRL Life Technologies, Inc., Gaithersburg, USA

Eppendorf, Hamburg

Eppendorf, Hamburg

Gilson Medical Electronics, Villiers-le-Bel,

Frankreich

PEQLAB Biotechnologie GmbH, Erlangen

Herolab, Wiesloch

MJ Research Incorporated, Alameda, USA

IKA Labortechnik, Staufen 
Sequenzierer MegaBace1000

Spannungsgerät Gene Power

Supply GPS 200/400

Thermomixer 5436

Thermomagnetrührer RCT basic

Thermomixer compact

UV-Bank UVT-25 M 3022 nm

Vortex-Genie2 $^{\mathrm{TM}}$

Waage 1574 A MP8-2

Wärmerüttler Clim-O-Shake®

Wärmeschrank Heraeus 6000

Zentrifugen

\subsubsection{Verbrauchsmaterialien}

96-Loch-Platte für Sephadex

96-Well PCR-Plate mit Rand

96-Well PCR-Plate ohne Rand

Adhesive Pcr Foil Seals

Aufreinigungsplatte NucleoFast ${ }^{\circledR}$ 96PCR

Epi-Cup

Falcon-Röhrchen

Filterpipettenspitzen

$(10 \mu \mathrm{l}, 20 \mu \mathrm{l}, 100 \mu \mathrm{l}, 200 \mu \mathrm{l}, 1000 \mu \mathrm{l})$

Invisorb MSB® Spin PCRapace
Amersham Biosciences, Freiburg

Pharmacia, Freiburg

Eppendorf, Hamburg

Schütt Labortechnik, Göttingen

Eppendorf, Hamburg

Bachofer, Reutlingen

Bender \& Hobein AG, Zürich, Schweiz

Sartorius, Göttingen

Adolf Kühner AG, Basel, Schweiz

Heraeus, Hamburg

Sigma Laborzentrifugen GmbH, Osterode am Harz

Medizintechnik, Göttingen

4titude, Berlin

4titude, Berlin

4titude, Berlin

Macherey-Nagel, Düren

Sarstedt, Nümbrecht

Sarstedt, Nümbrecht

Kisker Biotech GmbH \& Co. KG, Steinfurt

Invitek, Berlin 
Millipore-MAHV-N45-Platte

Parafilm®

Peha-soft-Handschuhe

Peel Seal

Petrischalen

Pipettenspitzen

Quarzküvette

\subsubsection{Chemikalien}

Agar-Agar

Capillary Array (16 capillaries)

my-Budget Universal Agarose

Antibiotika

Ampuwa

Borsäure

Chloroform

Diethylpyrocarbonat (DEPC)

dNTPs (100 mM Set, PCR Grade)

DYEnamic $^{\text {TM }}$ ET Terminator Cycle Sequencing Kit

EDTA

Ethidiumbromid

$\mathrm{EtOH}$

ET-Mix

Expand Long Template PCR System
Millipore, Schwalbach

Ochs Laborbedarf, Bovenden/ Lenglern

Paul Hartmann AG, Heidenheim

4titude, Berlin

Greiner Bio-One International GmbH, Frickenhausen

Sarstedt, Nümbrecht

Omnilab-Krannich GmbH, Göttingen

Carl Roth GmbH \& Co, Karlsruhe

GE-Healthcare, München

Bio-Budget, Krefeld

Sigma-Aldrich Chemie GmbH, Taufkirchen

Fresenius Kabi GmbH, Bad Homburg

Scharlau, Barcelona, Spanien

Sigma-Aldrich Chemie GmbH, Taufkirchen

Carl Roth GmbH \& Co, Karlsruhe

Low Budget, Krefeld; Invitrogen, Karlsruhe

Amersham Biosciences Europe $\mathrm{GmbH}$, Freiburg

MP Biomedicals, Eschwege

Eurobio, Courtaboeuf, Frankreich

Carl Roth GmbH \& Co, Karlsruhe

GE-Healthcare, München

Roche Diagnostics, Mannheim 
Ficoll 400

Glycerin

Glykogen

Hefe

HotStar HiFidelity-DNA-Polymerase

Hot Star Taq Master Mix

Immolase ${ }^{\mathrm{TM}}$ DNA-Polymerase

IPTG

Isopropanol

LongRange PCR Kit

Long Read Matrix

Mega Bace 10x Running-Buffer

Multiplex PCR Kit

$\mathrm{NaCl}$

Orange G

peqGOLD Pwo-DNA-Polymerase

Pepton

Phenol (ss)

Pfu DNA-Polymerase

Phusion High-Fidelity DNA-Polymerase Finnzymes, Espoo, Finnland

Platinum® Taq DNA-Polymerase

Proteinase K

Pwo SuperYield DNA-Polymerase

QIAGEN Plasmid Kit

QIAquick Gel Extraction Kit
Amersham Biosciences Europe GmbH, Freiburg

Carl Roth GmbH \& Co, Karlsruhe

Invitrogen, Karlsruhe

Carl Roth GmbH \& Co, Karlsruhe

QIAGEN GmbH, Hilden

QIAGEN GmbH, Hilden

Bioline, Luckenwalde

Biomol GmbH, Hamburg

Carl Roth GmbH \& Co, Karlsruhe

QIAGEN GmbH, Hilden

GE Healthcare, München

GE-Healthcare, München

QIAGEN GmbH, Hilden

Carl Roth GmbH \& Co, Karlsruhe

Sigma-Aldrich Chemie, Taufkirchen

PEQLAB Biotechnologie GmbH, Erlangen

Carl Roth GmbH \& Co, Karlsruhe

Biomol GmbH, Hamburg

Promega, Mannheim

Invitrogen, Karlsruhe

Carl Roth GmbH \& Co, Karlsruhe

Roche Diagnostics, Mannheim

QIAGEN GmbH, Hilden

QIAGEN GmbH, Hilden 
Restriktionsenzyme

RNAse

RNAse-freies Wasser

SDS

6x Loading Dye solution

Sephadex G50

S.O.C.-Medium

SuperScript ${ }^{\mathrm{TM}}$ II Reverse Transcriptase

Synthetische Oligonukleotide $100 \mathrm{pmol} / \mu \mathrm{l}$

Total RNA Kit

Tris

Trizol® RNA Total Isolation Reagent

T4-DNA-Ligase

X-Gal
Biolabs, Beverly, USA; Invitrogen, Karlsruhe

QIAGEN GmbH, Hilden

QIAGEN GmbH, Hilden

Serva, Heidelberg

MBI Fermentas, St. Leon-Rot

Amersham Biosciences Europe $\mathrm{GmbH}$, Freiburg

Invitrogen, Karlsruhe

Invitrogen, Karlsruhe

Eurofins MWG Synthesis GmbH, Ebersberg;

QIAGEN GmbH, Hilden

PEQLAB Biotechnologie $\mathrm{GmbH}$, Erlangen

Carl Roth GmbH \& Co, Karlsruhe

Invitrogen, Karlsruhe

Roche Diagnostics, Mannheim

Biomol GmbH, Hamburg

\subsubsection{Stammlösungen, Puffer, Medien}

$\begin{array}{ll}\text { DEPC- } \mathrm{H}_{2} \mathrm{O} & 0,1 \%(\mathrm{v} / \mathrm{v}) \text { Diethylpyrocarbonat } \\ & \text { Inkubation für } 24 \text { h unter Rühren } \\ & \text { und anschließend Dampfdrucksterilisation } \\ & 10 \mathrm{mM} \text { dATP } \\ \text { dNTP-Mix } & 10 \mathrm{mM} \mathrm{dCTP} \\ & 10 \mathrm{mM} \mathrm{dGTP} \\ & 10 \mathrm{mM} \mathrm{dTTP} \\ & 155 \mathrm{mM} \mathrm{NH}_{4} \mathrm{Cl}\end{array}$




\begin{tabular}{|c|c|}
\hline & $10 \mathrm{mM} \mathrm{KHCO}_{3}$ \\
\hline & $0,1 \mathrm{mM}$ EDTA \\
\hline IPTG & $100 \mathrm{mM}$ in $\mathrm{H}_{2} \mathrm{O}$ \\
\hline Ladepuffer & $15 \%$ Ficoll 400 \\
\hline & $1 \mathrm{mM}$ EDTA \\
\hline & $0,01 \%$ Orange G \\
\hline & $10 \%$ Glycerin \\
\hline LB-Medium & $1 \%(w / v)$ Pepton \\
\hline & $0,5 \%(w / v)$ Hefeextrakt \\
\hline & $1 \%(w / v) \mathrm{NaCl}$ \\
\hline & $\mathrm{pH} 7,2$ mit $5 \mathrm{M} \mathrm{NaOH}$ einstellen \\
\hline Lysepuffer & $100 \mathrm{mM} \mathrm{NaCl}$ \\
\hline & 100 mM Tris/HCl $(\mathrm{pH} 8,0)$ \\
\hline & 100 mM EDTA \\
\hline & $0,2 \mathrm{mg} / \mathrm{ml}$ Proteinase $\mathrm{K}$ \\
\hline & $0,5 \%$ SDS \\
\hline PBS & $130 \mathrm{mM} \mathrm{NaCl}$ \\
\hline & $7 \mathrm{mM} \mathrm{Na}_{2} \mathrm{HPO}_{4}$ \\
\hline & $3 \mathrm{mM} \mathrm{NaH}_{2} \mathrm{PO}_{4} \times 2 \mathrm{H}_{2} \mathrm{O}$ \\
\hline Puffer P1 für Plasmidisolation & $50 \mathrm{mM}$ Tris/HCl $(\mathrm{pH} 8,0)$ \\
\hline & 10 mM EDTA \\
\hline & $100 \mu \mathrm{g} / \mathrm{ml}$ RNAse A \\
\hline Puffer P2 für Plasmidisolation & $200 \mathrm{mM} \mathrm{NaOH}$ \\
\hline & $1 \%$ SDS \\
\hline Puffer P3 für Plasmidisolation & $3 \mathrm{M} \mathrm{K}$-Acetat-H-Acetat (pH 5,5) \\
\hline TBE-Puffer (5x) & $10 \mathrm{mM}$ EDTA \\
\hline & 225 mM Tris (pH 8,3) \\
\hline
\end{tabular}


225 mM Borsäure

TE- Puffer

$10 \mathrm{mM}$ Tris/HCl $(\mathrm{pH} 8)$

$1 \mathrm{mM}$ EDTA

SE-Puffer

$75 \mathrm{mM} \mathrm{NaCl}$

1 mM EDTA

$(\mathrm{pH} 8,0)$

$\operatorname{SSC}(20 \mathrm{x})$

$3 \mathrm{M} \mathrm{NaCl}$

0,3 M Natriumcitrat ( $\mathrm{pH} 7$ mit $\mathrm{NaOH}$ )

Stoppmix

$40 \%$ Saccharose

0,25\% Bromphenolblau

$0,25 \%$ Xylencyanol

Waschlösung I

$2 \times$ SSC

$1 \%$ SDS

Waschlösung II

$0,2 \times S S C$

$1 \% \operatorname{SDS}$

X-Gal-Stammlösung

$20 \mathrm{mg} \mathrm{X-Gal/ml}$

in N,N-Dimethylformamid

\subsubsection{Autoklavierverfahren}

Vor der Nutzung von Gebrauchslösungen wurden diese für 20 min bei $120^{\circ} \mathrm{C}$ und $10^{5} \mathrm{~Pa}$ in einem Dampfdruckautoklaven sterilisiert. Die Gebrauchswaren wurden zunächst gewaschen und getrocknet und abschließend autoklaviert oder ü. N. bei $180^{\circ} \mathrm{C}$ hitzesterilisiert.

\subsubsection{Molekulargewichtstandards}

DNA-Längenstandard $(1 \mu \mathrm{g} / \mu \mathrm{l})$

DNA 1 Kb-Leiter $(0,12-12,2 \mathrm{~Kb})$

DNA 100 Bp-Leiter (Invitrogen, Karlsruhe) 


\subsubsection{Bakterienstämme}

Zur Vermehrung von Plasmiden wurden kompetente Zellen des E. coli-Stammes K12 DH5a (Hanahan 1985) von der Firma Invitrogen (Karlsruhe) genutzt.

\subsubsection{Vektoren}

Als Plasmid-Vektor diente der pGEM-T Easy Vector mit einer Länge von $3 \mathrm{~Kb}$ von Promega (Mannheim).

\subsubsection{Antibiotika}

Es wurde eine Arbeitslösung mit einer Endkonzentration von $100 \mu \mathrm{g} / \mathrm{ml}$ angesetzt, indem das Antibiotikum Ampicillin $(50 \mathrm{mg} / \mathrm{ml})$ in $\mathrm{H}_{2} \mathrm{O}$ gelöst wurde. Diese Lösung wurde steril filtriert und konnte bei $-20^{\circ} \mathrm{C}$ gelagert werden.

\subsubsection{OYA-Platten/ Ampicillin-IPTG/ X-Gal-Plattten}

Zunächst wurden $10 \mathrm{~g}$ Pepton mit $5 \mathrm{~g}$ Hefe und $10 \mathrm{~g} \mathrm{NaCl}$ in 1 I Wasser zur Herstellung von LB-Medium in einer Glasflasche autoklaviert. Im Anschluss wurden zu $500 \mathrm{ml}$ dieser Lösung $7,5 \mathrm{~g}$ Agar gegeben. Nach Absinken der Temperatur auf unter $40^{\circ} \mathrm{C}$ wurden $1 \mathrm{ml} \mathrm{X-Gal}(2 \%)$, $1 \mathrm{ml}$ Ampicillin-Arbeitslösung und $500 \mu \mathrm{l}$ IPTG unter die Lösung gemischt. Am Ende wurden nun Petrischalen bis zur Hälfte mit dem Gemisch bedeckt und bei $4^{\circ} \mathrm{C}$ bis zu ihrer Verwendung gelagert.

\subsubsection{Mäusestämme}

In den institutseigenen Tierställen wurden die Mäuse des Stammes 129SV gezüchtet. Bei einer Raumtemperatur von $22^{\circ} \mathrm{C}$ lebten sie in einem zwölfstündigen Hell-Dunkel-Rhythmus und wurden mit einer pelletierten Zuchtdiät (Herilan, Eggersmann, Rinteln) und Wasser ad libitum versorgt.

\subsubsection{Organe und Gewebeproben}

Für Expressionsanalysen wurden zur Isolierung von RNA Organe des Mausestammes 129SV aus dem institutseigenen Tierstall präpariert. Die Proben der untersuchten Patienten stammen von der Universitätsklinik Göttingen, auswärtigen Kliniken und Fachärzten für Humangenetik. 


\subsubsection{Synthetische Oligonukleotide}

Die verwendeten Oligonukleotide wurden bei der Firma QIAGEN GmbH (Hilden) oder Eurofins MWG Synthesis GmbH (Ebersberg) bestellt. Nach der Verdünnung der Stocks mit Ampuwa (Endkonzentration: $100 \mathrm{pmol} / \mu \mathrm{l}$ ) wurden die Stocklösungen bei $-20^{\circ} \mathrm{C}$ aufbewahrt.

2.1.13.1 Oligonukleotide für die Amplifikation und Sequenzierung des Kandidatengens CHD8

\section{Bezeichnung}

CHD8 2F

CHD8 2R

CHD8 3F

CHD8 3R

CHD8 4.1F

CHD8 4.1R

CHD8 4.2F

CHD8 4.2R

CHD8 5F

CHD8 5R

CHD8 6F

CHD8 6R

CHD8 7F

CHD8 7R

CHD8 8F

CHD8 8R

CHD8 9F

CHD8 9R

CHD8 10F
Sequenz 5'-3'

TATGTCCGTCCTCAGATTTCCT

GGAGGGTACTTCTCCAAGGTCT

TTGCATCAAGACAGATAGGATGA

GGCAACAGCAATGGACTAAGTA

TGAGCTTGATTCTTGAGGGATT

TCTTTGGCTTCTCCTCTTTCAG

AAGAAACGCAGGAAGAAGAGTG

GCAAGGAGCACTCGAGCTTA

AAGGGTCAGTCAGTGGTTTACAA

TGGCTTGGTTAGCCATAATTAAA

ATTCTTGGCCTTTCATAAAGCA

ACAGATGATTGTGACCAGCAAG

ATGATTTCAGAGGATTGCCTTG

TGACATCCAAAGGTGCTCATTA

TGAAGTTCTGCAATGTGTGGTT

AGCAACCTGGGCTACAAGACTA

ACAGTAGCCTGCCACCTTCTT

CATGTGCATTGAGGAAATCAGT

ACACCCATCGGATAGCTTCTAA 


\section{Bezeichnung}

CHD8 10R

CHD8 11F

CHD8 11R

CHD8 12F

CHD8 12R

CHD8 13F

CHD8 13R

CHD8 14F

CHD8 14R

CHD8 15F

CHD8 15R

CHD8 16F

CHD8 16R

CHD8 17F

CHD8 17R

CHD8 18F

CHD8 18R

CHD8 19F

CHD8 19R

CHD8 20F

CHD8 20R

CHD8 21F

CHD8 21R

CHD8 22F

CHD8 22R
Sequenz 5'-3'

AAACCCACCAGCAGAAATCTAA

GGAGCAGAGAACACAGAATCAG

GGCCTTTATACTTTAATGCAAATGT

ACCTTTTGATAATGTCTCCACTCC

GCTTACATCTTATGGCCCATTC

GAATGGGCCATAAGATGTAAGC

GTACCTTGGCCGACTTTCTCTA

GTGGTGCAGTTTGTATTGCCTA

CAGGTGTTTCTGCTCACAAGTC

GTCAGAGGGATTTCTTGAATGC

ATGACAACAGATGTCTGCCTTG

TTCGCCCTCATCTTATTGATTT

CCCAAATTAGGTTGGTTGAGTC

TTGTGCTGAAATTCTGTGTGTG

GGTCAAAAACCCAAGTTGAGAG

CTCCACTTCTGCTTAGCCACTT

CTGCCACCCTTAACTAAGGAAA

TTTTGTATCCTTTCCCTTGCT

TGTTTCCCTCTATCACAATGATCT

GGCATGGTTAGATATTATTCTCTTGA

AGAGATTCCGGTCTCTGTGTTT

AGTCAGCTTTACCTCTGCATTTG

GACTCCCGAAAGTAGTGTGGTC

CATGAGCAAATCAGGAAGAGAA

AACAGAACAAACTCCCTCCAAG 


\section{Bezeichnung}

CHD8 23F

CHD8 23R

CHD8 24/25F

CHD8 24/25R

CHD8 26F

CHD8 26R

CHD8 27F

CHD8 27R

CHD8 28F

CHD8 28R

CHD8 29/30F

CHD8 29/30R

CHD8 31F

CHD8 31R

CHD8 32.1F

CHD8 32.1R

CHD8 32.2F

CHD8 32.2R

CHD8 33F

CHD8 33R

CHD8 34F

CHd8 34R

CHD8 35F

CHD8 35R

CHD8 36F
Sequenz 5'-3'

CTTGGAGGGAGTTTGTTCTGTTT

CAGGGATAGATAGACCTGGGAAA

GACTTGATTAGCCCAGCTGAAA

TAAGCAAACCAATCTTCCCTCA

CCTTTGCAAGGATTCTCACTTT

GCTAAATGTTCCATCCGTGAA

TCCAGCAGCATATAAAGTAAGCA

GCTAGAGTTATTTCACGGCACA

CATGCTGGATATATGTGTGGCTA

CCCTACTGGCATTACAGTCCTT

GCCATAGAAGGACACACACAAG

ATGGCTTTCAGTATAGGGACCA

TGTTGCCCTACTTTTCCTTTTG

ATGGGCTCAATGAACAGGTTAG

TGGTAAGCAAGATTGCAGAGTG

GGGAAACCAGAGGGGTAGTATC

ACCAACCCCACAAGACTATGAG

TTGAATAAAGGCCCAAAGAATG

CATTCTTTGGGCCTTTATTCAA

GGACTCTACATGTCCAGGGATG

CTGGTAGTGATGGCACTATTGAGT

AAATTAGTTACAGCAAGGATTCCAG

AGAGGATGACCTATAGCCCACA

TCCCACTGCCTTCATCAATTA

CCCAATAATTGATGAAGGCAGT 


$\begin{array}{ll}\text { Bezeichnung } & \text { Sequenz 5' } \mathbf{3} ' \\ \text { CHD8 36R } & \text { TTAAATCTTGCTGGATGGGACT } \\ \text { CHD8 37F } & \text { GCATGAGAAAGAGAAAGCATGA } \\ \text { CHD8 37R } & \text { GGAATAGAGTGGTAATGCTGCAA } \\ \text { CHD8 38.1F } & \text { AGCTAGGACTCTGTTGGCTTTG } \\ \text { CHD8 38.1R } & \text { AGTCACTGGTGAAGAGGGGTAG } \\ \text { CHD8 38.2F } & \text { ACCATCATCCCCTCATGTAGAC } \\ \text { CHD8 38.2R } & \text { CAAGGGCCAGAGTAAATGAAAA }\end{array}$

2.1.13.2 Oligonukleotide für die Amplifizierung und Sequenzierung des Kandidatengens FAM124B

Bezeichnung

FAM124B Ex 1.1F

FAM124B Ex 1.1R

FAM124B Ex.1.2F

FAM124B Ex.1.2R

FAM124B Ex 1.3F

FAM124B Ex 1.3R

FAM124B Ex.2.1F

FAM124B Ex.2.1R

FAM124B Ex.2.2F

FAM124B Ex.2.2R

FAM124B Ex 3.1F

FAM124B Ex 3.1R

FAM124B Ex 3.2F

FAM124B Ex 3.2R

\section{Sequenz 5'-3'}

GCCGGTCATTTCCTGTACTAAG

CTGTCCAGGCTGTAGAACTCCT

CCTTCTACACACGCTGTCTTTG

ATCTTGTTGCCATCGTAGTCCT

TTTGTTTCTTCGTGCTCTATGC

GAAAGGAGGCCGATTCTTTAAT

CCTATTAAAGAATCGGCCTCCT

CACGGCAGCTATCATGACTAAA

AGCCTTCCTTTGTAACCATCCT

TGCTGCACACACACATTACATT

GCAGAGGGTGAATAAGGCATAG

GCTGATTCTGGGTCAGTACTCC

GACCTTGGTACCAGGAAGACAA

CAAGGAGGGTATGTGAACAAGG 
Bezeichnung

FAM124B Ex 3.3F

FAM124B Ex 3.3R

FAM124B Ex1.2neuR

FAM124B Ex1.1R Neu

FAM124B Ex1.2Fneu2

FAM124B Ex1.2Rneu2

FAM124B Ex 1.1gR
Sequenz 5'-3،

TGTGTTGAATCCAGCACCTATC

TCAGAGTGGTGAAACCATAAACAC

CTTCAGGGAGAGCTGCAGAG

AAAGTAGGGACACAGCCTTCC

TCCTGGACTCTCTCCAGCAT

AAACTGCAGCACCGAAGACT

CACTAACTGGCCGATCTCTTG

\subsubsection{Oligonukleotide für die Haplotypanalyse im Gen CHD7}

\section{Bezeichnung}

CHD7 Diag Ex2.1F

CHD7 Diag Ex2.2R

CHD7 Diag Ex2.3R

CHD7 Diag Ex2.4R

CHD7 Diag Ex2.5F

CHD7 Diag Ex2.5R

CHD7 Diag Ex5F

CHD7 Diag Ex5R

CHD7 Diag Ex6R

CHD7 Diag Ex9F

CHD7 Diag Ex9R

CHD7 Diag Ex9 Int.F

CHD7 Diag Ex10R

CHD7 Diag Ex19F
Sequenz 5'-3'

GGATTATAGGCTTTGAGGGCAAAC

TGGCAATAAAAGGATTTCCCTGAT

GGGGTATCTTGGTACGGACTGATT

GGACATGCCTATAAATGGACGAGA

GTTATCCAAATATGCCCCATCCTC

TTCGATCAGACAAGTTAGCCATGTT

TTAATTTCAAGGCCACTGTCTTGG

ATGCTTCCACTGCACTTCTCAGAT

GCCAACAATCCTGTAAGAGTCACA

AAGACCCAGTTAACGAAGTCTGAGAA

AAACATGTATGGGTTGCCTGAATC

TGGTGTAGATTGAGGATGAGCTT

CCCAAAGACCACACCACTATGC

AGCATTTGTTTAGTCTGCAAACCTCT 


\section{Bezeichnung}

CHD7 Diag Ex19R

CHD7 Diag Ex23F

CHD7 Diag Ex23R

CHD7 Diag Ex26F

CHD7 Diag Ex25F

CHD7 Diag Ex26R

CHD7 Diag Ex27/28F

CHD7 Diag Ex31.1F

CHD7 Diag Ex32F

CHD7 Diag Ex34.1F

CHD7 Diag Ex34.1R

CHD7 Diag Ex34.2F

CHD7 Diag Ex34.2R

SNP CHD7 In1.1F

SNP CHD7 E2-I2F

SNP CHD7 E2-I2R

SNP CHD7 In2Anf.F

SNP CHD7 In2Anf.R

SNP CHD7 In2E3NeuF

SNP CHD7 In3NeuR

SNP CHD7 In4F

SNP CHD7 In4R

SNP CHD7 In4NeuF

SNP CHD7 In4NeuR
Sequenz 5'-3'

CCCAATGCATCTTGTAAGCACTTT

TTTGTGCTACAGGGTCACAAAGC

AAAGGGAATTAAGCTCTCCAGGTC

AACAAGGTCCACTTGGATTCAACA

GCTCAGATGTTTATCGTGGGAGAG

ACCCTGCCAATAGATGTGAAACTG

GGGCAGATTATTACTCTTTCCTACCC

CCCTTGAATTCTCCCCAAGTAAATA

CAGTTTCCCTGATACTGTGGTTGTG

CAGTACTGTTTTGGCTCACTGCAA

ACTAGGGAGCCATTAAGGAGATGC

GCTTCGAGAGTCTCAGGTGGTC

CTCAGCTGTCAACACGTGCAAT

GCTCTGTGTCAGTGCAGACTGG

CGGTCAGATGGGTGTCTACC

AGGGAGATTGATGCCTGAATAA

ATGGGAATCGGACAGAGGAATA

CCTTCTGGTCCAAACTGTCCTC

GGAGGCTGTTGTATGCAGGAGT

GATTCGGATTAACCAAGGCTGAC

TACTGGGATTGTGTTCATCCTG

GTGTAGCGCTTTCTCTTCACCT

TGTTCTGTTCCATTTGCTTCTC

CAACTCTGACTCTTCCTCAGCA 


\begin{tabular}{|c|c|}
\hline Bezeichnung & Sequenz 5'-3' \\
\hline SNP CHD7 In7NeuF & ATCCTGGAGGAACACAGTCTGG \\
\hline SNP CHD7 IN8F & GCTGCTTACTAGGGTCTCTGGA \\
\hline SNP CHD7 In8R & GCAGCCTAAGGAGAAACAAAGA \\
\hline SNP CHD7 I9-I11F & TTTGGCTTTCGAACATCACTTA \\
\hline SNP CHD7 I9-I11R & CACACTGCTGTCATTTCACAAA \\
\hline SNP CHD7 Ex9F & CCCAGTTAACGAAGTCTGAGAAG \\
\hline SNP CHD7 Ex9R & AGCTAGCAAATAGCAAAGCTGAA \\
\hline SNP CHD7 I12F & GCCAAATTGAGAAATTTGCTTT \\
\hline SNP CHD7 I12R & GCGTACCCATTCTAGTCACACA \\
\hline SNP CHD7 In12.2R & TTCCTAACAGAGCACATGCATCAA \\
\hline SNP CHD7 In12.3R & ACCACTAAGCGTACCCATTCTAGTCA \\
\hline SNP CHD7 In14F & ATACCCTTTCCTTGGACTTTCC \\
\hline SNP CHD7 In14R & CAGTGCATGAAGGTTGCATAAT \\
\hline SNP CHD7 Ex15F & TCATACTCTCACTGGGCTTTGA \\
\hline SNP CHD7 Ex15R & GCGAATGCTCCCTTCTTATTTA \\
\hline SNP CHD7 Ex17R & AACCTATCAGAATCAGGTTTGGAG \\
\hline SNP CHD7 I16-E18F & TCATTCAAAGACGGTGAGGAC \\
\hline SNP CHD7 I16-E18R & TAAATAAATGGTTTGGGCAAGG \\
\hline SNP CHD7 In21F & CTGTGGGTAACTTTAGGAATGGA \\
\hline SNP CHD7 In21R & CAATTCACACTGGGTGATAGGA \\
\hline SNP CHD7 Ex $22 F 2$ & ACCCAGTGTGAATTGTTGCTAGT \\
\hline SNP CHD7 Ex 22R2 & AGGGAATTAAGCTCTCCAGGTC \\
\hline SNP CHD7 E22-I23F & GTAGGTCTCCACCATGCTGTTT \\
\hline SNP CHD7 E22-I23R & GAACCCCAAGCAATGAAATAAA \\
\hline
\end{tabular}




\section{Bezeichnung}

SNP CHD7 I25-E26F

SNP CHD7 I25-E26R

SNP CHD7I25E26F_N

SNP CHD7I25E26R_N

SNP CHD7 E26-I28F

SNP CHD7 E26-I28R

SNP CHD7 I27-E28F

SNP CHD7 I27-E28R

SNP CHD7 E28-I28F

SNP CHD7 E28-I28R

SNP CHD7 E31-I31F

SNP CHD7 E31-I31R

SNP CHD7 I31F

SNP CHD7 I31R

SNP CHD7 Ex32R

SNP CHD7 I32-I33F

SNP CHD7 I32-I33R

SNP CHD7 I34F

SNP CHD7 I34R
Sequenz 5'-3'

TCCCTCTTAATTGGAGTGTTCAA

CATCTGCTAGCATGTCTGTTCC

TTTGAATGTTTGTTGAGCATTTG

ACTGAACCCTGCCAATAGATGT

AACAAACTTGTGTTGTGGCAGT

GCAAATGCTCTATGCTCTATTCC

AACCAGAACACCGTTCAAAGAT

TTCAAATGACAGTGTGGGAAAG

CACAGGTAAGGTCCCAGAAAAG

TTCAAATGACAGTGTGGGAAAG

GTTGGATTTGTCCAGACTCCTC

GTTCCAGCTACAGCACAGTACG

TCTTCTGTGAAGGGATAATTTCAA

TAGAGACAGCTCCTGCTGAGAA

CACTTCAAATTTCATTGAAGCGTGT

AATGAGCTTCAGTCAGCCTACC

TCCAACAGAACAGAGTTGCAGT

TGAACGAAGTGTAGCTTGAGGA

CCTGCCATCTTATTAAGCTTTCTC

\subsubsection{Oligonukleotide für die RT-PCR}

\section{Bezeichnung}

CHD7 RT Ex22-24F

CHD7 RT Ex22-24R
Sequenz 5'-3'

AGAAACCATCTGCAGAACCATC

TCACTTGAGTCAGCACCCTCTA 


\section{Bezeichnung}

Fam124BHu RT-F

Fam124BHu RT-R

Fam124BMausRT-F

Fam124BMausRT-R

GAPDHHuRT-F

GAPDHHuRT-R

GAPDHMuRT-F

GAPDHMuRT-R
Sequenz 5'-3'

CCTTCTACACACGCTGTCTTTG

GGGATGAGCTATGCAACCTAAG

GGTGGCCTTCATCATAATCTTC

CCAGTCACACTCTTGCTTCTGT

CTGCACCACCAACTGCTTAG

CAGTGAGCTTCCCGTTCAG

CACCACCAACTGCTTAGCC

CGGACACATTGGGGGTAGG

2.1.13.5 Oligonukleotide für die Amplifizierung der DNA und die Yq11-PCR

\section{Bezeichnung}

D4 S126 F Fam

D4 S126 R

D11 S874 F Fam

D11 S874 R

D11 S1328 F Fam

D11 S1328 R

D17 S1290 F Fam

D17 S1290 R

D19 S254 F Fam

D19 S254 R

D5S208 CA Fam

D5S418 F Fam

D5S418 R Fam
Sequenz 5'-3'

GGATCCTGTCACTGTACTCCAGGC

TGCTTAACCAGTTTGACCATGAGG

CCTTCACAGGGTTCATTTTTCCAGGGG

CTGGGCTGCAGCGAAGATAGTCCCTG

AAAGGCAAAGAACAGCACTAATGAGG

AATGCTGAGCCTGCTCTTGGAAC

GCAACAGAGCAAGACTGTCC

GACCAGGTGTCTCATAAGGG

TTCTGAGCACAACCAATCCTCCCAAG

GAATTGCTTGAACCTGGGAGGTGGAG

ACCTGAGTGTTCATCAATAC

TAGCCTTCAAAACAGGAAATGTTAC

GGAAACAATGATGACATCTCCAA 


\begin{tabular}{|c|c|}
\hline Bezeichnung & Sequenz 5'-3' \\
\hline IVS8CA F Fam & AАATCTATCTCATGTTAATGCTC \\
\hline IVS8CA R Fam & ACTAAGATATTTGCCCATTATCA \\
\hline IVS17bCA F Fam & TGTCACСTCTTCATACTCATAT \\
\hline IVS17bCA R Fam & AAACTTACCGACAAGAAGAAC \\
\hline $\mathrm{D} 21 \mathrm{~S} 1411 \mathrm{~F}$ & GATGAATGCATAGATGGATGGC \\
\hline D21S1411 R & GTGTGTCCTTCCAGGCTTTCTC \\
\hline \multicolumn{2}{|l|}{ Multi A } \\
\hline SYR F & GAATATTCCCGCTCTCCGGA \\
\hline SYR R & GCTGGTGCTCCATTCTTGAG \\
\hline SY254F & GGGTGTTACCAGAAGGCAAA \\
\hline SY254R & GAACCGTATCTACCAAAGCAG \\
\hline SY143F & GCAGGATGAGAAGCAGGTAG \\
\hline SY143R & CCGTGTGCTGGAGACTAATC \\
\hline SY255F & GTTACAGGATTCGGCCTGAT \\
\hline SY255R & CTCGTCATGTGCAGCCAC \\
\hline
\end{tabular}

\subsubsection{Datenbanken und Computeranalysen}

Programm

\begin{tabular}{l|l}
\hline Primer3 & http://bioinfo.ut.ee/primer3/ \\
BDGP & http://www.fruitfly.org/ \\
Blatsearch & http://www.genome.ucsc.edu/ \\
Ensembl & http://www.ensembl.org \\
$\mathrm{NCBI}$ & http://www.ncbi.nlm.nih.gov/ \\
Repeat masking & http://www.repeatmasker.org \\
HGVS & http://www.hgvs.org/varnomen
\end{tabular}

http://bioinfo.ut.ee/primer3/

\section{Internetadresse}

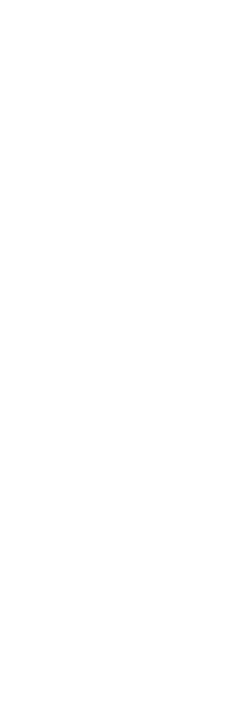

AAATCTATCTCATGTTAATGCTGAAGA

ACTAAGATATTTGCCCATTATCAAGTT

GTCACCTCTTCATACTCATATTGG

AAACTTACCGACAAGAAGAACTCTG

CTCGTCATGTGCAGCCAC 
Für die Erkennung von repetitiven Sequenzen in der zu untersuchenden DNA wurde das Programm repeat masking verwendet. Für den Entwurf von Oligonukleotidsequenzen wurde das Programm Primer3 angewandt. Um eine hohe Spezifität der Primer zu gewährleisten, wurde der Genome Browser von Blatsearch benutzt. Die Auswirkung einer Splice-siteMutation wurde mithilfe des Splice-site prediction-Programmes von BDGP avisiert. Jegliche Referenzsequenzen von Genen wurden auf den Webseiten von Ensembl und NCBI abgerufen.

\subsection{Methoden}

\subsubsection{Isolierung genomischer DNA aus peripherem Blut}

Zunächst wurden zur Lyse der Erythrozyten ca. $5 \mathrm{ml}$ EDTA-Blut mit $30 \mathrm{ml} 4^{\circ} \mathrm{C}$ kaltem Erythrozyten-Lysepuffer gemischt und für $30 \mathrm{~min}$ auf Eis gelegt. Daraufhin erfolgte eine Zentrifugation für $15 \mathrm{~min}$ bei $2.000 \times \mathrm{g}$, der Überstand wurde abgegossen und das entstandene Pellet in $30 \mathrm{ml}$ Lysepuffer resuspendiert. Dieser Vorgang von Zentrifugation und Resuspendierung wurde mehrmals wiederholt, bis das Leukozytenpellet keine rötliche Färbung mehr durch Hämoglobin aufwies.

Im Anschluss wurde das Pellet in $5 \mathrm{ml}$ SE-Puffer resuspendiert, mit $250 \mu$ l Proteinase $\mathrm{K}$ $(10 \mathrm{mg} / \mathrm{dl})$ versetzt, $500 \mu \mathrm{l}$ SDS hinzugegeben und bei $55^{\circ} \mathrm{C}$ im Wasserbad ü. N. verdaut. Das SDS hat die Fähigkeit, die vorhandenen Zellmembranen aufzulösen, die Proteinase $\mathrm{K}$ baut die zellulären Proteine ab. Am nächsten Tag wurden $1,5 \mathrm{ml}$ gesättigte $\mathrm{NaCl}$-Lösung hinzugegeben, für $15 \mathrm{sec}$ gevortext und $15 \mathrm{~min}$ bei RT bei $3.000 \mathrm{xg}$ zentrifugiert. Im Anschluss wurde der Überstand mit 1,3 ml Glykogen in einem neuen Tube vermischt, und die DNA wurde mittels 2 Volumina $100 \% \mathrm{EtOH}$ innerhalb von $3 \mathrm{~h}$ bei $-20^{\circ} \mathrm{C}$ ausgefällt. Das sich absetzende DNA-Knäuel wurde mit $500 \mu \mathrm{l} 70 \% \mathrm{EtOH}$ gewaschen und nachdem das $\mathrm{EtOH}$ verdampft war, in $500 \mu \mathrm{l} 1 \mathrm{x}$ TE-Puffer gegeben.

\subsubsection{Konzentrationsbestimmung der Nukleinsäuren}

Zur Bestimmung der Nukleinsäurekonzentrationen wurde eine photometrische Messung in einem Spektralphotometer durchgeführt. Dazu wurde $1 \mu \mathrm{l}$ der RNA- oder DNA-Probe mit $300 \mu \mathrm{l} \mathrm{H}_{2} \mathrm{O}$ verdünnt. Nach Nulleichung des Gerätes wurde die Extinktion (E) der Proben bei 260 und $320 \mathrm{~nm}$ gemessen. Mithilfe der Formel $C=(E 260-E 320) \times f \times \varepsilon$ wurde die Konzentration errechnet.

$\mathrm{C}=$ Konzentration der Probe $(\mu \mathrm{g} / \mu \mathrm{l})$ 
E260 $=$ Absorption bei $260 \mathrm{~nm}$

E320 = Absorption bei $320 \mathrm{~nm}$

$\mathrm{f}=$ Verdünnungsfaktor

$\varepsilon=$ Absorptionskoeffizient

\subsubsection{Isolierung von Gesamt-RNA aus peripherem Blut (PEQLAB Total RNA Kit)}

Für die Isolierung von RNA aus peripherem Blut wurden ca. 7,5 ml EDTA-Blut mit ca. $42 \mathrm{ml}$ Erythrozyten-Lysepuffer versetzt und für 30 min auf Eis gestellt. Im Anschluss wurden $300 \mu \mathrm{l}$ Lysepuffer und $150 \mu \mathrm{l}$ Proteinase K (1mg/dl) hinzugegeben. Nach Vortexen für $30 \mathrm{sec}$ wurde die Probe für $10 \mathrm{~min}$ bei $70^{\circ} \mathrm{C}$ inkubiert. Im Folgenden wurde der Ansatz bei $10.000 \mathrm{xg} 3 \mathrm{~min}$ zentrifugiert. Nun wurde die Probe nach Überführen in die Shredder-Säule 1 min lang bei $12.000 \times \mathrm{g}$ zentrifugiert. Der Durchfluss wurde in einem neuen Epi-Cup mit $225 \mu \mathrm{l}$ $100 \% \mathrm{EtOH}$ versetzt, darauffolgend in eine Blindsäule gegeben und für $1 \mathrm{~min}$ bei $10.000 \mathrm{xg}$ zentrifugiert. Nach Zugabe von $500 \mu \mathrm{l}$ Waschpuffer I und Zentrifugation für $15 \mathrm{sec}$ bei $10.000 \times g$ erfolgte die 2. Waschung mit $600 \mu \mathrm{l}$ Waschpuffer II. Die 2. Waschung wurde wiederholt. Wichtig bei diesen Reinigungsschritten war die Verwerfung des Durchflusses. Abschließend wurde die Säule in ein neues 2-ml-Epi-Cup gegeben und trocken zentrifugiert. In einem neuen Epi-Cup wurde die Säule mit ca. $50-100 \mu \mathrm{l} \mathrm{H}_{2} \mathrm{O}$ versetzt und 1 min bei $5.000 \times$ g zentrifugiert. Zur Kontrolle der erfolgreichen RNA-Isolation wurden ca. $3 \mu$ in ein $1 \%$ iges Testgel aufgetragen. Die gewonnene RNA wurde bei $-80^{\circ} \mathrm{C}$ gelagert.

\subsubsection{Isolierung von Gesamt-RNA aus Mausgeweben}

Die gewünschten Organe wurden mithilfe eines sterilen Präparierbestecks den Mäusen entnommen und nach kurzer Spülung in 1 x PBS-Puffer in einem Falcon-Röhrchen sofort in Flüssigstickstoff schockgefroren. Anschließend wurde nach der Gewichtsbestimmung zu 100 mg Gewebe $1 \mathrm{ml}$ RNA-Reagenz zugegeben, mit einem Dispergierwerkzeug (Ultraturrax T25, Schütt, Göttingen) homogenisiert und 5 min auf Eis inkubiert. Nach der Zugabe und Mischung mit $200 \mu \mathrm{l}$ Chloroform erfolgte nach erneuter Inkubation von 5 min eine Zentrifugation von $15 \mathrm{~min}$ bei $19.000 \mathrm{xg}$ und $4{ }^{\circ} \mathrm{C}$. Dabei entstehen drei Phasen, die untere rot gefärbte Phase enthält Proteine und weitere Zellbestandteile und Phenol-Chloroform, die Interphase und die obere wässrige Phase enthalten die gewünschte RNA. Diese obere Phase wurde in ein neues Schraubfalcon überführt, mit $500 \mu$ l Isopropanol gemixt und für $10 \mathrm{~min}$ auf Eis inkubiert. Nach Zentrifugation von $10 \mathrm{~min}$ bei $12.000 \mathrm{xg}$ und $4^{\circ} \mathrm{C}$ wurde das entstandene Pellet durch Zugabe von $1 \mathrm{ml} 75 \% \mathrm{EtOH}$ gewaschen und erneut bei $13.000 \times \mathrm{g}$ für $5 \mathrm{~min}$ bei $4{ }^{\circ} \mathrm{C}$ abzentrifugiert. Der gebildete Überstand wurde verworfen, das Pellet bei 
$56^{\circ} \mathrm{C}$ für $2 \mathrm{~min}$ getrocknet und abschließend in 50-200 ml DEPC- $\mathrm{H}_{2} \mathrm{O}$ gelöst. Die Konzentrationsbestimmung erfolgte über die Messung der optischen Dichte (s. 2.2.2). Die erfolgreiche Isolation wurde mithilfe einer RT-PCR mit GAPDH-Primern (GAPDHMuRT-F/R) (s. 2.1.13.4, 2.2.9) getestet. Die RNA konnte bei $-80^{\circ} \mathrm{C}$ bis zur weiteren Verwendung gelagert werden.

\subsubsection{Polymerase-Kettenreaktion (PCR)}

Mit dieser Methode nach Mullis und Faloona (1987) lassen sich genau definierte DNAFragmente in vitro amplifizieren. Dabei kommt es durch die Abfolge von Zyklen, bestehend aus Denaturierung, Anlagerung und Verlängerung, zu einer exponentiellen Vermehrung des zu vervielfältigenden DNA-Stückes. Dieser Zuwachs kann mit folgender Gleichung beschrieben werden:

$\left(2^{n}-\mathbf{2 n}\right) \mathbf{x} \quad \mathrm{n}:$ Anzahl der Zyklen

2n: Produkte des ersten und zweiten Zyklus, deren Dauer nicht definiert sind.

$\mathrm{x}$ : Anzahl der Kopien der ursprünglichen DNA-Matrize.

Zur Anlagerung von Oligonukleotidprimern, die die Spezifität der Vervielfältigung des entsprechenden DNA-Stückes sichern, wird der DNA-Doppelstrang zunächst hitzedenaturiert. Die hitzestabile DNA-Polymerase kann dadurch in einer spezifischen Kettenreaktion in 5'-3'-Richtung die Einzelstränge zu Doppelsträngen auffüllen. Für die weiteren Zyklen stehen sowohl die neu synthetisierten Stränge als auch die ursprünglich eingesetzte DNA als Matrizen für den nächsten Zyklus zur Verfügung. Allerdings muss bedacht werden, dass mit zunehmender Zykluszahl die Effizienz der DNA-Polymerase abnimmt, da einerseits die z. T. hohen Temperaturen, die notwendig für die Denaturierung der DNA sind, und andererseits das im Reaktionsverlauf zunehmende saure Milieu auf das Enzym schädigend wirken.

Für sämtliche PCR-Reaktionen standen die Thermocycler Primus 25 advanced® oder PTC$100^{\text {TM }}$ Thermal Cycler zur Verfügung.

\subsubsection{PCR an genomischer DNA zur Abklärung aussagekräftiger Polymorphismen}

Zur Vervielfältigung spezifischer Sequenzen genomischer DNA wurde diese, wie oben beschrieben, aus Lymphozyten extrahiert (s. 2.2.1). Es wurde folgender Reaktionsansatz durchgeführt $(25 \mu \mathrm{l})$ : 


$\begin{array}{lc}\text { Template-DNA }(300-500 \mathrm{ng}) & 0,8 \mu \mathrm{l} \\ \text { Taq-Immolase } & 0,2 \mu \mathrm{l} \\ \text { Primer F }(10 \mathrm{pmol} / \mu \mathrm{l}) & 0,5 \mu \mathrm{l} \\ \text { Primer R }(10 \mathrm{pmol} / \mu \mathrm{l}) & 0,5 \mu \mathrm{l} \\ \text { Puffer } & 2,5 \mu \mathrm{l} \\ \mathrm{MgCl}_{2} & 0,75 \mu \mathrm{l} \\ \text { dNTP } & 0,5 \mu \mathrm{l}\end{array}$

ad $\mathrm{H}_{2} \mathrm{O}$ bis $25 \mu \mathrm{l}$

Nach der Länge des zu amplifizierenden DNA-Fragments und der spezifischen Anlagerungstemperatur der eingesetzten Primer wurden die Zyklustemperaturen und Zeitintervalle der Touch down- PCR verändert.

\begin{tabular}{|c|c|c|c|}
\hline Programm: & $95^{\circ} \mathrm{C}$ & $7 \min$ & \\
\hline & $94^{\circ} \mathrm{C}$ & $30 \mathrm{sec}$ & \\
\hline & $65^{\circ} \mathrm{C}-60^{\circ} \mathrm{C}$ & $1 \mathrm{~min}$ & 5 Touch-Down-Zyklen \\
\hline & $72^{\circ} \mathrm{C}$ & $1 \mathrm{~min}$ & \\
\hline & $94^{\circ} \mathrm{C}$ & $30 \mathrm{sec}$ & \\
\hline & $60^{\circ} \mathrm{C}$ & $1 \mathrm{~min}$ & 33 Zyklen \\
\hline & $72^{\circ} \mathrm{C}$ & $1 \mathrm{~min}$ & \\
\hline & $72^{\circ} \mathrm{C}$ & $5 \mathrm{~min}$ & \\
\hline
\end{tabular}

\subsubsection{PCR an genomischer DNA nach Auffinden eines aussagekräftigen Polymorphismus}

Für die Amplifizierung der spezifischen Sequenz wurden unterschiedliche Polymerasen getestet:

- Pfu DNA-Polymerase

- LongRange PCR Kit

- Pwo SuperYield DNA-Polymerase

- Expand Long Template PCR System 
- HotStar HiFidelity-DNA-Polymerase

- Phusion High-Fidelity DNA-Polymerase

- peqGOLD Pwo-DNA-Polymerase

Für die Haplotypbestimmung konnten im weiteren Verlauf jedoch nur die Phusion HighFidelity-, HotStar HiFidelity- oder peqGOLD Pwo-DNA-Polymerasen genutzt werden. Diese besitzen eine sog. Proofreading-Aktivität, welche für die Haplotypanalyse von entscheidender Bedeutung ist.

\subsubsection{Amplifizierung mit HotStar HiFidelity-DNA-Polymerase}

Die Amplifizierung der spezifischen Sequenzen erfolgte nach folgendem Reaktionsansatz $(25 \mu l)$ :

DNA-Template

HotStar HiFidelity-DNA-Polymerase

Primer $\mathrm{F}$

Primer R

Puffer (enthält dNTPs)

RNAse freies Wasser

Programm:

$\begin{array}{lc}95^{\circ} \mathrm{C} & 5 \mathrm{~min} \\ 94^{\circ} \mathrm{C} & 15 \mathrm{sec} \\ 59^{\circ} \mathrm{C} & 1 \mathrm{~min} \\ 72^{\circ} \mathrm{C} & 2 \mathrm{~min} \\ 72^{\circ} \mathrm{C} & 10 \mathrm{~min}\end{array}$

$0,5 \mu \mathrm{l}$

$0,5 \mu \mathrm{l}$

$2,5 \mu \mathrm{l}$

$2,5 \mu l$

$5 \mu \mathrm{l}$

$14 \mu \mathrm{l}$

35 Zyklen

\subsubsection{Amplifizierung mit Phusion High-Fidelity DNA-Polymerase:}

Ansatz: $20 \mu \mathrm{l}$

$\mathrm{H}_{2} \mathrm{O}$

$12,4 \mu \mathrm{l}$ 
$4 \mu \mathrm{l}$

Primer $\mathrm{F}$

$1 \mu \mathrm{l}$

Primer R

$1 \mu \mathrm{l}$

dNTPs

$0,4 \mu \mathrm{l}$

Phusion High-Fidelity DNA-Polymerase

$0,2 \mu \mathrm{l}$

DNA-Template

$1 \mu \mathrm{l}$

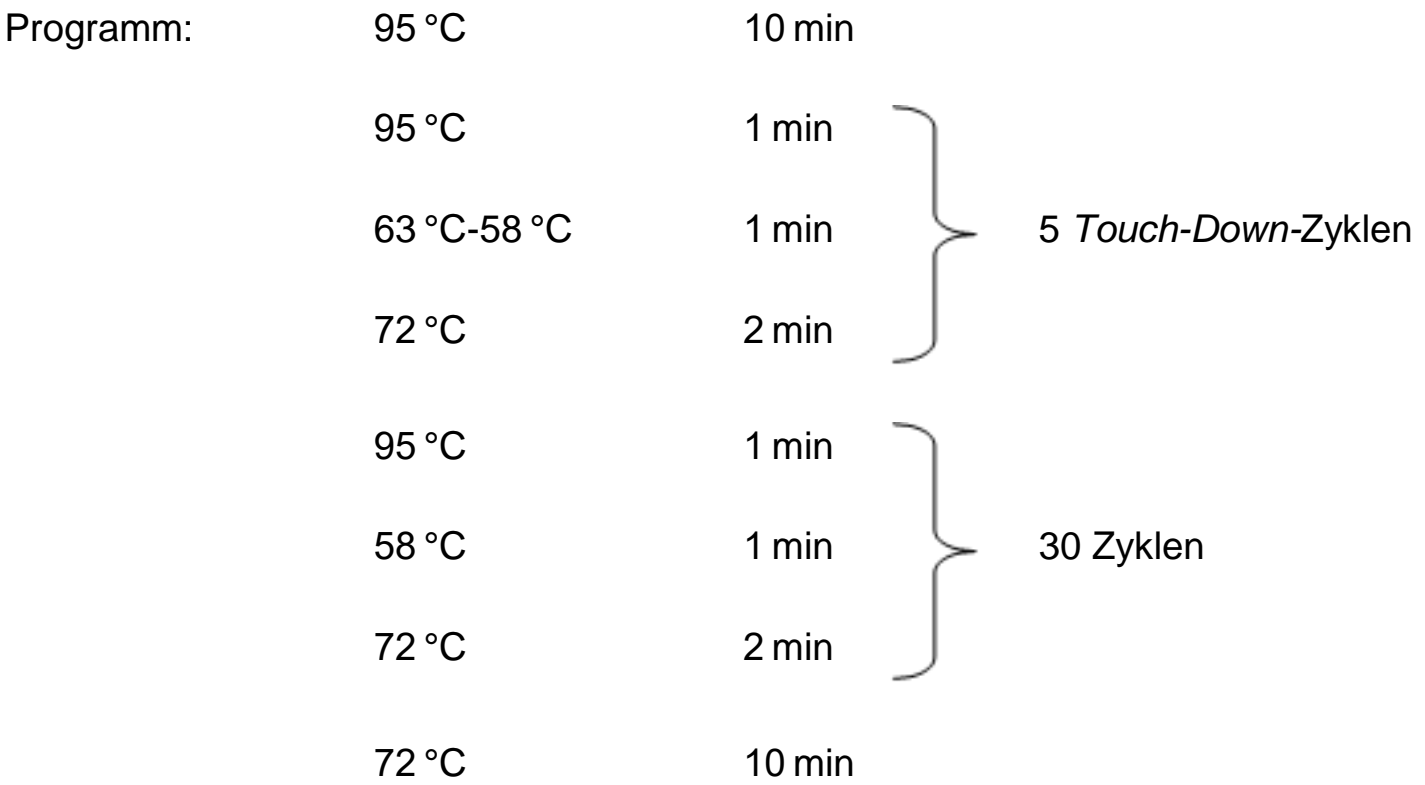

\subsubsection{Amplifizierung mit peqGOLD Pwo-DNA-Polymerase:}

Ansatz: $50 \mu \mathrm{l}$

Master Mix 1

$\begin{array}{lc}\text { dNTPs } & 4 \mu \mathrm{l} \\ \text { Primer F } & 1,5 \mu \mathrm{l} \\ \text { Primer R } & 1,5 \mu \mathrm{l} \\ \text { DNA-Template } & 1 \mu \mathrm{l} \\ \mathrm{H}_{2} \mathrm{O} & 17 \mu \mathrm{l}\end{array}$




\section{$\underline{\text { Master Mix } 2}$}

$10 \times$ Puffer

$5 \mu l$

peqGOLD Pwo-DNA-Polymerase

$3 \mu \mathrm{l}$

$\mathrm{H}_{2} \mathrm{O}$

$17 \mu \mathrm{l}$

Bei wenigen Primerpaaren musste die $\mathrm{MgSo}_{4}-$ Konzentration im Puffer erhöht werden.

\begin{tabular}{|c|c|c|}
\hline \multirow[t]{5}{*}{ Programm: } & $94^{\circ} \mathrm{C}$ & $2 \min$ \\
\hline & $94^{\circ} \mathrm{C}$ & $15 \mathrm{sec}$ \\
\hline & $58^{\circ} \mathrm{C}$ & $30 \mathrm{~min}$ \\
\hline & $68^{\circ} \mathrm{C}$ & $1,5-2 \mathrm{~min}$ \\
\hline & $68^{\circ} \mathrm{C}$ & $7 \mathrm{~min}$ \\
\hline
\end{tabular}

\subsubsection{A-Überhänge}

Für die Ligation in den Vektor pGEM-T Easy ist ein Desoxyadenosin-Überhang an dem entsprechenden Insert notwendig. Da die Phusion High-Fidelity DNA-Polymerase und die peqGOLD Pwo-DNA-Polymerase keine Überhänge synthetisieren, war es notwendig, AÜberhänge an die PCR-Produkte in einem weiteren Schritt zu generieren. Das Anhängen des Desoxyadenosin-Überhanges erfolgte nach folgendem Reaktionsansatz (10 $\mu$ l):

$7 \mu \mathrm{l} \quad$ aufgereinigtes PCR-Produkt

$1 \mu \mathrm{l} \quad$ Platinum ${ }^{\circledR}$ Taq DNA-Polymerase $(5 \mathrm{U} / \mu \mathrm{l})$

$1 \mu \mathrm{l} \quad 10 \times$ Puffer $\left(15 \mathrm{mM} \mathrm{MgCl}_{2}\right)$

$1 \mu \mathrm{l} \quad \mathrm{dATP}(2 \mathrm{mM})$

Nach einer 30 min lang andauernden Inkubation bei $70^{\circ} \mathrm{C}$ stand das jeweilige PCR-Produkt für die Ligation zur Verfügung. 


\subsubsection{PCR nach reverser Transkription (RT-PCR)}

Für die cDNA-Synthese diente die aus humanem oder murinem Gewebe extrahierte mRNA als Matrize für die Reverse Transkriptase. Hierfür wurde die SuperScript ${ }^{\mathrm{TM}}$ II Reverse Transcriptase (Invitrogen, Karlsruhe) angewandt. Die RT-PCR ermöglicht eine Aussage über die Expression der RNA in dem untersuchten Gewebe, doch lassen sich keine Aussagen über die mögliche Transkriptgröße machen.

Für die Erststrangsynthese wurde ca. $1 \mathrm{ng}-5 \mu \mathrm{g}$ mRNA eingesetzt. $1 \mathrm{ml}$ Oligo (dT) ${ }_{12-18}$ Primer $(500 \mathrm{mg} / \mathrm{ml})$ und $1 \mu \mathrm{l}$ dNTP-Mix $(10 \mathrm{mmol} / \mathrm{l})$ wurden zu der mRNA hinzugegeben. Für ein gewünschtes Gesamtvolumen des Reaktionsansatzes von $13 \mu \mathrm{l}$ wurde entsprechend destilliertes RNAse-freies Wasser hinzugesetzt. Nach einer Hitzedenaturierung der RNA von $5 \mathrm{~min}$ bei $65^{\circ} \mathrm{C}$ wurden $4 \mu \mathrm{l} 5 \times$ First-Strand Buffer und $2 \mu \mathrm{l} 0,1$ MDTT dem Reaktionsgemisch auf Eis zugegeben. Nach $2 \mathrm{~min}$ Inkubation bei $42^{\circ} \mathrm{C}$ wurde die SuperScript ${ }^{\mathrm{TM}}$ II Reverse Transcriptase beigemischt und dieser Reaktionsansatz für 50 min bei $42^{\circ} \mathrm{C}$ inkubiert. Abschließend erfolgte die Inaktivierung des Enzyms für 15 min bei $70^{\circ} \mathrm{C}$.

Die Intaktheit der cDNA wurde in einer nachfolgenden PCR mithilfe der Primer GAPDHHuRT-F und GAPDHHuRT-R (s. 2.1.13.4) für das Haushaltsgen Glycerinaldehyd-3phoshpat-dehydrogenase kontrolliert.

\subsubsection{Restriktionsanalyse von DNA}

Restriktionsendonukleasen besitzen die Fähigkeit, spezifisch an bestimmte Nukleotidsequenzen der DNA, in der Regel Palindrome, zu binden. Sie enthalten drei Untereinheiten: die S-Untereinheit für die Erkennung der DNA-Sequenz, die M-Untereinheit für die Methylierung und die R-Sequenz für das Schneiden der DNA.

Für optimale Reaktionsbedingungen ist die Zugabe eines auf das jeweilige Restriktionsenzym abgestimmten Puffers notwendig.

Folgender Reaktionsansatz wurde verwendet $(10 \mu l)$ :

$8 \mu \mathrm{l} \quad$ PCR-Produkt $(\sim 0,2-1 \mu \mathrm{g})$

$1 \mu \mathrm{l} \quad 10 \mathrm{x}$ Reaktionspuffer $(10 \mathrm{U} / \mu \mathrm{l})$

$1 \mu \mathrm{l} \quad$ Restriktionsenzym

Der Ansatz wurde je nach Restriktionsenzym bei $37^{\circ} \mathrm{C}$ in einem Thermocycler für 2-3 oder 4$6 \mathrm{~h}$ inkubiert. Im Anschluss wurde der Reaktionsansatz für die Analyse komplett auf ein 
$3 \%$ iges Agarosegel aufgetragen, elektrophoretisch aufgetrennt und das Gel wurde photographiert.

\subsubsection{Auftrennung von DNA in Agarosegelen}

Agarose gehört zu den Polysacchariden aus D-Galaktose und 3,6-Anhydro-L-Galaktose, welche über Glycosidbindungen miteinander vernetzt sind. Die Agarosegel-Elektrophorese in einer Horizontalkammer wurde zur Auftrennung und Identifizierung von PCR-Produkten genutzt. Dabei wurden Gele mit 1\%iger Agarose verwendet. Durch eine höhere Konzentration an Agarose ist die Herstellung eines Netzwerkes mit kleineren Poren im Vergleich zu einem Gel mit niedrigerer Konzentration an Agarose und entsprechend größeren Poren möglich. Die Auftrennung eines Gemisches von mehreren DNA-Fragmenten in einem elektrischen Feld basiert auf der negativen Nettoladung der DNA, welche unabhängig von ihrer Größe konstant ist. Über einen Vergleich mit Nukleinsäurefragmenten bekannter Größe kann die Größe der DNA-Fragmente erfasst werden.

Es wurde eine entsprechende Menge Agarose, abhängig sowohl von dem benötigten Volumen als auch der gewünschten Agarosekonzentration, in 0,5\% TBE-Puffer für 2-3 min in der Mikrowelle gelöst und emulgiert. Um die DNA-Banden im Agarosegel sichtbar zu machen, erfolgte nun die Zugabe von Ethidiumbromid (Endkonzentration $0,5 \mu \mathrm{g} / \mathrm{ml}$ ). Anschließend wurde der Ansatz in einen Gelträger gegossen und ein Plastikkamm für die Geltaschen hineingesteckt. Sobald das Gel erhärtet war und eine milchig getrübte Farbe aufwies, wurde es in eine Gelkammer mit TBE-Laufpuffer gegeben. Die Proben wurden nach dem Zusatz von einem Ladepuffer, der zur Erhöhung der Dichte der Proben führt, in die einzelnen Taschen pipettiert.

In eine Geltasche wurde ein Größenmarker gegeben, um die Bandengröße der jeweiligen DNA-Fragmente verifizieren zu können. Unter einer angelegten Spannung von 80-120 V erfolgte die Auftrennung der DNA. Ein Transilluminator diente zur photographischen Dokumentation der Auftrennung: Mithilfe des Fluoreszenzfarbstoffes Ethidiumbromid, der in die DNA interkalierte, konnten die DNA-Fragmente nun mithilfe des Transilluminators unter UV-Licht bei $302 \mathrm{~nm}$ sichtbar gemacht werden.

\subsubsection{Isolierung von DNA-Fragmenten aus Agarosegelen}

Da die DNA sehr empfindlich auf UV-Licht reagiert, wurde die gewünschte DNA-Bande zügig unter UV-Licht aus dem Agarosegel herausgeschnitten und mithilfe des QIAquick Gel Extraction Kit aus dem Gel isoliert. Nach Protokoll des Herstellers wurde das entsprechende Gelstück eines $1 \%$ igen Agarosegels zunächst mit 3 Volumen QG-Puffer in einem 2-ml- 
Röhrchen versetzt. Zur vollständigen Auflösung des Gelstückes wurde es für 10 min bei $50^{\circ} \mathrm{C}$ geschüttelt. Im Anschluss erfolgte die Überführung in eine Säule, die eine SilicaMembran enthält. Nach zweimaliger Zentrifugation für jeweils 1 min bei $15.000 \times \mathrm{g}$ wurde das Pellet in $750 \mu \mathrm{l}$ Waschpuffer (PE-Puffer) resuspendiert, bei RT 2-5 min inkubiert und erneut zweimal für jeweils $1 \mathrm{~min}$ bei $15.000 \times \mathrm{g}$ zentrifugiert. Die DNA wurde mit $30 \mu \mathrm{dH}_{2} \mathrm{O}$ eluiert und abschließend bei $15.000 \times \mathrm{g}$ für $1 \mathrm{~min}$ zentrifugiert. Zur Kontrolle der erfolgreichen Gelextraktion wurden $2 \mu \mathrm{l}$ der gelösten DNA mit $2 \mu$ l Ladepuffer auf ein $1 \%$ iges Agarosegel aufgetragen, elektrophoretisch aufgetrennt und photometrisch dokumentiert.

\subsubsection{Aufreinigung von PCR-Produkten}

Zur Reinigung der entstandenen PCR-Produkte von überschüssigen Primern, Salzen und dNTPs wurden verschiedenen Aufreinigungsmethoden genutzt, abhängig von der Anzahl der Proben.

\subsubsection{Invisorb MSB®Spin PCRapace}

Hierfür wurde die Probe mit ca. $250 \mu$ l Bindungspuffer versetzt und anschließend in eine Säule überführt. Nach Zentrifugation von $3 \mathrm{~min}$ bei $13.400 \mathrm{xg}$ wurde die Säule in ein neues

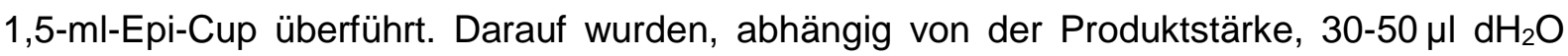
gegeben. Zur Lösung der PCR-Produkte aus der Membran wurde das Epi-Cup nach einer Inkubation von $1 \mathrm{~min}$ bei RT abschließend $1 \mathrm{~min}$ bei $9.300 \mathrm{xg}$ zentrifugiert.

\subsubsection{NucleoFast ${ }^{\circledR 96 P C R}$}

Die PCR-Produkte wurden mit $100 \mu \mathrm{H}_{2} \mathrm{O}$ verdünnt und auf eine Nucleo-Fast-Platte pipettiert. Nach der Zugabe von weiteren $100 \mu \mathrm{l} \mathrm{H}_{2} \mathrm{O}$ erfolgte eine Zentrifugation von 15 min bei $1.000 \times \mathrm{g}$. Der Durchlauf in der Auffangplatte wurde verworfen, und nach erneuter Zugabe von $100 \mu \mathrm{l} \mathrm{H}_{2} \mathrm{O}$ wurde die Platte 20 min bei 1.000 x g zentrifugiert. Abhängig von der Produktstärke im zuvor gelaufenen Agarosegel wurden zu den Proben jeweils $30-50 \mu \mathrm{l} \mathrm{H}_{2} \mathrm{O}$ zugegeben und in eine neue 96-Well PCR-Platte überführt. Mit einer Folie verschlossen wurden die Proben bei $-20^{\circ} \mathrm{C}$ gelagert. 


\subsubsection{Klonierung aufgereinigter PCR-Produkte}

Für die Ligation der PCR-Produkte wurde der Vektor pGEM-T Easy (Promega, Mannheim) genutzt. Dieser Vektor enthält an seinen Insertionsstellen ein 3' überhängendes Thymin. Für eine Thymin-Adenosin-Ligation ist es notwendig, dass das Insert an seinem 3'-Ende zusätzlich ein Desoxyadenosin während der Elongationszyklen der PCR bekommen hat. Falls die in der PCR genutzte Polymerase nicht diese Eigenschaft besitzt, musste nachfolgend ein A-Überhang erfolgen (s. 2.2.8).

Der folgende Ligationsansatz $(10 \mu \mathrm{l})$ wurde nach Herstellerangaben verwendet:

$3 \mu \mathrm{l} \quad$ Insert-DNA

$5 \mu \mathrm{l} 2 \times$ Puffer

$1 \mu \mathrm{l} \quad$ Vektor-DNA

$1 \mu \mathrm{l}$ T4-DNA-Ligase

Die Inkubation erfolgte ü. N. bei $4^{\circ} \mathrm{C}$. Das Enzym T4-DNA-Ligase katalysiert hierbei unter ATP-Verbrauch die Ausbildung von Phosphodiesterbindungen, sodass die DNA-Fragmente kovalent an den Vektor gebunden werden können.

\subsubsection{Transformation von Plasmiden in E. coli-DH5a-Zellen}

Für die ausreichende Vermehrung wurden die DNA-Insert enthaltenden Vektoren in DH5aZellen transformiert. Dazu wurde der Ligationsansatz zu einem Aliquot kompetenter Zellen von $50 \mu \mathrm{l}$ zugegeben und 30 min lang auf Eis inkubiert. Nach einer Hitzeschockerwärmung bei $37^{\circ} \mathrm{C}$ für $35 \mathrm{sec}$ wurde nach einer $5 \mathrm{~min}$ dauernden Inkubation auf Eis $200 \mu \mathrm{l}$ S.O.C.Medium hinzugegeben und bei $37^{\circ} \mathrm{C}$ für mindestens eine Stunde geschüttelt. Danach erfolgte die Ausplattierung auf OYA-Selektions-Platten. Diese beimpften Platten wurden ü. N. bei $37^{\circ} \mathrm{C}$ in einem Wärmeschrank inkubiert. Durch eine Blau-Weiß-Selektion konnten am nächsten Tag einzelne Bakterienkolonien gepickt werden. Jene gewünschte Selektion beruht darauf, dass das sog. lacZ'-Gen in der Klonierungsstelle des Vektors liegt und durch die Insertion des DNA-Fragments unterbrochen wird. Dieses lacZ'-Gen kodiert für das $\alpha$ Fragment der ß-Galactosidase, die nur ihre Galactosidaseaktivität ausüben kann, wenn das $\omega$-Fragment durch den Bakterienstamm exprimiert wird. Folglich färben sich die Bakterienkolonien ohne Insertion des DNA-Fragments nach der Inkubation mit IPTG und XGal blau, während diejenigen, die das Insert eingebaut haben, weiß bleiben und gepickt 
werden. Die Bakterienkolonien wurden entweder zum Animpfen von Minipräparationsansätzen genutzt oder direkt in einer PCR amplifiziert.

\subsubsection{Isolierung von Plasmid-DNA mithilfe von Minipräparation}

Für die Präparation wurde das QIAGEN Plasmid Kit verwendet. Nach dem Protokoll des Herstellers wurden hierfür in einem 14-ml-Falcon-Röhrchen $5 \mathrm{ml}$ LB-Medium zunächst mit einem Selektivantibiotikum, z. B. Ampicillin, versetzt und anschließend mit einer einzelnen Bakterienkolonie beimpft. Dieser Ansatz wurde ü. N. bei $37^{\circ} \mathrm{C}$ in einem Rüttel-Inkubator angezüchtet. Am folgenden Tag wurden $\mathrm{zu}$ jeweils $800 \mu \mathrm{l}$ der einzelnen Bakteriensuspensionen $500 \mu \mathrm{l} 80 \%$ Glycerin zur Herstellung von Glycerinkulturen hinzugegeben und bei $-80^{\circ} \mathrm{C}$ gelagert. Der verbliebene Rest der Kultur wurde für 10 min bei $4.000 \times \mathrm{g}$ und $4^{\circ} \mathrm{C}$ zentrifugiert. Nach dem Verwerfen des Überstandes wurde das entstandene Pellet in $200 \mu \mathrm{l}$ Puffer P1 resuspendiert und in ein neues Epi-Cup überführt. Durch die Zugabe von $200 \mu$ Puffer P2 wurde die Bakterienkultur bei RT 5 min lang alkalisch lysiert und abschließend durch Hinzugabe von $200 \mu$ Puffer P3 neutralisiert. Nach Zentrifugation von $10 \mathrm{~min}$ bei $13.000 \mathrm{xg}$ und RT war die Plasmid-DNA im Überstand gelöst. Das entstandene Pellet enthielt präzipitierte Zellproteine, Membranbestandteile und die genomische Bakterien-DNA.

Der Überstand wurde in ein neues Epi-Cup überführt und zur vollständigen Entfernung von Protein- und Zellresten nochmal bei $13.000 \times \mathrm{g}$ und RT für $10 \mathrm{~min}$ zentrifugiert. Die PlasmidDNA wurde danach in einem neuen Epi-Cup durch die Zugabe von $100 \mathrm{ml} 100 \% \mathrm{EtOH}$ und einer Inkubationszeit von 5-10 min und abschließender Zentrifugation von $30 \mathrm{~min}$ bei $13.000 \times \mathrm{g}$ und $4^{\circ} \mathrm{C}$ ausgefällt. Das entstandene Pellet wurde nachfolgend zweimal mit $200 \mathrm{ml} 70 \% \mathrm{EtOH}$ gewaschen und für $5 \mathrm{~min}$ bei $13.000 \times \mathrm{g}$ und $4^{\circ} \mathrm{C}$ zentrifugiert. Im

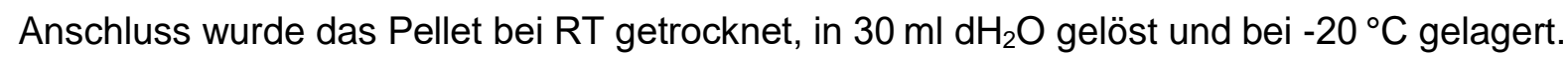

\subsubsection{Sequenzierung von PCR-Produkten}

Die DNA-Sequenzierung wurde nach dem Kettenabbruchverfahren nach Sanger et al. (1977) durchgeführt. Bei dieser Methode handelt es sich um die Analyse der primären, linearen Basenzusammensetzung der DNA.

In einer zyklischen Reaktion aus Denaturierung, Primer-Anlagerung und Elongation kann die DNA-Polymerase einen komplementären DNA-Strang bilden, beginnend am Ende eines eingesetzten Oligonukleotidprimers. Neben den vier dNTPs, der Taq-Polymerase und einem Reaktionspuffer sind in dem verwendeten DYEnamic ${ }^{\mathrm{TM}}$ ET Terminator Cycle Sequencing Kit 
auch mit vier verschiedenen Fluoreszenzfarbstoffen markierte ddNTPs enthalten, bei denen jedes ddNTP einen für die jeweilige Base spezifischen terminalen Fluoreszenzfarbstoff trägt. Sobald diese ddNTPs in den neu entstehenden DNA-Strang eingebaut werden, erfolgt ein Abbruch der Synthese und es entstehen unterschiedliche große DNA-Fragmente nach dem Zufallsprinzip.

Werden nun diese Fluoreszenzfarbstoffe angeregt (z. B. durch einen Argon-Laser), emittiert jedes der ddNTPs eine Fluoreszenz-charakteristische Wellenlänge, sodass eine Unterscheidung zwischen den vier Bausteinen (ddATP, ddCTP, ddGTP und ddTTP) möglich ist. Nach elektrophoretischer Auftrennung in einer hochauflösenden Matrix werden die unterschiedlich langen Sequenzierprodukte durch Fluorographie sichtbar gemacht und ein Rückschluss auf die Sequenz ist möglich.

Für die beschriebene Sequenzier-Reaktion wurden zu $5 \mu \mathrm{l}$ des aufgereinigten PCRProduktes $1 \mu \mathrm{l}$ Primer $(10 \mathrm{pmol} / \mu \mathrm{l})$ und $4 \mu \mathrm{l}$ DYEnamic ${ }^{\mathrm{TM}}$ ET Terminator Cycle Sequencing Ready Reaction Mix gegeben. In diesem Mix waren dNTPs, fluoreszenzmarkierte dNTPs, Ampli-taq-Polymerase und Reaktionspuffer enthalten.

Die Proben wurden entsprechend des nachfolgenden Programmes mit 25 Zyklen in Thermocyclern amplifiziert:

$\left.\begin{array}{lll}\text { Vordenaturierung } & 2 \mathrm{~min} & 94^{\circ} \mathrm{C} \\ \text { Denaturierung } & 20 \mathrm{sec} & 94^{\circ} \mathrm{C} \\ \text { Annealing } & 20 \mathrm{sec} & 60^{\circ} \mathrm{C} \\ \text { Elongation } & 2 \mathrm{~min} & 60^{\circ} \mathrm{C}\end{array}\right\} 25$ Zyklen

Nach Zugabe von $10 \mu \mathrm{l} \mathrm{H}_{2} \mathrm{O}$ erfolgte nach der Aufreinigung auf einer Sephadex-Säule die Sequenzanalyse im Sequenzierer MegaBace1000.

\subsubsection{Aufreinigung von Sequenzierprodukten für den Megabace-Sequenzierer}

Die Sequenzierprodukte unterlagen einer Aufreinigung, da die Salzkonzentration in den Proben minimiert werden musste. Die Salzionen würden sonst mit der DNA konkurrieren und aufgrund ihrer höheren Mobilität eher in die Kapillaren gelangen. Außerdem war mit der Aufreinigung auch sichergestellt, dass überschüssige dNTPs eliminiert wurden, welche die Emission der Fluoreszenzfarbstoffe verfälschen würden. 
Hierfür wurden zunächst die DNA-Fragmente abzentrifugiert, sodass die Salze und kleineren Moleküle in der Sephadex-Säule verblieben. Zeitgleich wurden die Näpfe einer MilliporeMAHV-N45-Platte mit $4 \mathrm{~g}$ Sephadex-G-50-Pulver beschichtet. Nach Hinzugabe von $300 \mu \mathrm{l}$ $\mathrm{dH}_{2} \mathrm{O}$ quillte das Sephadex-Pulver, eingepackt in eine luftdicht verschlossene Plastiktüte, wahlweise über $3 \mathrm{~h}$ bei RT oder ü. N. im Kühlschrank.

Anschließend wurden die Sequenzierprodukte nach erneuter Zugabe von $100 \mu \mathrm{d}_{2} \mathrm{O} 5 \mathrm{~min}$ bei 910 x g abzentrifugiert. Nun konnten diese mit einer Mehrkanalpipette auf das Sephadex aufgetragen werden und bei einer Zentrifugation von $5 \mathrm{~min}$ bei $910 \mathrm{xg}$ in eine 0,2 $\mathrm{ml}-96$-Well PCR-Platte filtriert werden. Das Filtrat wurde entweder sofort in den Sequenzierer MegaBace1000 überführt oder bei $-20^{\circ} \mathrm{C}$ gelagert.

\subsubsection{Mikrosatellitenanalyse zur Überprüfung der Familientriplets}

Es wurde eine sog. Mikrosatellitenanalyse durchgeführt, um zu überprüfen, ob die jeweilige kindliche DNA-Probe zu den entsprechend elterlichen DNA-Proben gehört, $d$. h. es wurde eine Verwechselung der Proben vor Beginn der Untersuchungen überprüft. Die DNA der aussagekräftigen Familientriplets wurden hierfür nach folgendem Reaktionsansatz mit dem Hot Star Taq Master Mix vervielfältigt $(25 \mu l)$ :

Für Primer: D4S126 F Fam, D4S126 R, D11 S874 F Fam, D11 S874 R, D11 S1328 F Fam, D11 S1328 R, D17 S1290 F Fam, D17 S1290 R, D19 S254 F Fam, D19 S254 R (s. 2.1.13.5)

$\begin{array}{lc}\mathrm{H}_{2} \mathrm{O} & 9,5 \mu \mathrm{l} \\ \text { Primer } \mathrm{F}(10 \mu \mathrm{M}) & 1 \mu \mathrm{l} \\ \text { Primer R }(10 \mu \mathrm{M}) & 1 \mu \mathrm{l} \\ \text { Polymerase } & 12,5 \mu \mathrm{l} \\ \text { Template } & 1 \mu \mathrm{l}\end{array}$

PCR-Programm: $\quad 95^{\circ} \mathrm{C} \quad 15 \mathrm{~min}$

$\left.\begin{array}{ll}95^{\circ} \mathrm{C} & 30 \mathrm{sec} \\ 61^{\circ} \mathrm{C} & 30 \mathrm{sec} \\ 72^{\circ} \mathrm{C} & 30 \mathrm{sec}\end{array}\right\} 30$ Zyklen



$72{ }^{\circ} \mathrm{C}$
$5 \min$

Für Primer D5S208 CA Fam, D5S418 F Fam, D5S418 R Fam, IVS8CA F Fam, IVS8CA R Fam, IVS17bCA F Fam, IVS17bCA R Fam, D21S1411 F, D21S1411 R (s. 2.1.13.5).

\begin{tabular}{|c|c|c|c|}
\hline PCR-Programm: & $95^{\circ} \mathrm{C}$ & $15 \min$ & \\
\hline & $95^{\circ} \mathrm{C}$ & $30 \mathrm{sec}$ & \\
\hline & $63^{\circ} \mathrm{C}-58^{\circ} \mathrm{C}$ & $1 \mathrm{~min}$ & 5 Touch-Down-Zyklen \\
\hline & $72^{\circ} \mathrm{C}$ & $1 \mathrm{~min}$ & \\
\hline & $95^{\circ} \mathrm{C}$ & $30 \mathrm{sec}$ & \\
\hline & $58^{\circ} \mathrm{C}$ & $1 \mathrm{~min}$ & 33 Zyklen \\
\hline & $72^{\circ} \mathrm{C}$ & $1 \mathrm{~min}$ & \\
\hline & $72^{\circ} \mathrm{C}$ & $5 \mathrm{~min}$ & \\
\hline
\end{tabular}

Im Anschluss wurden je $5 \mu \mathrm{l}$ der entstandenen PCR-Produkte mit $5 \mu$ l Ladepuffer zur Kontrolle in ein $1 \%$ iges Agarosegel in 0,5 x TBE gegeben.

Anschließend wurde von den Proben je nach Stärke des PCR-Produktes auf dem Agarosegel eine Verdünnung hergestellt.

Daraufhin wurde für die Analyse der Fragmentlängen der PCR-Produkte mithilfe des $A B I$ genetic Analyzer 3130 folgender Reaktionsansatz geschaffen (10,15 $\mu \mathrm{l}$ Ansatz):

$1 \mu$ Template

$9 \mu \mathrm{l} \mathrm{HiDi-Formamid} \mathrm{(hochdeionisiertes} \mathrm{Formamid)}$

$0,15 \mu$ Standard GeneScan-500 ROX

Zum Schluss wurden die Fragmentgrößen mithilfe der Software Gene Mapper Version 4.0 (Applied Biosystems, Foster City, USA) mit dem Standard verglichen. 


\subsubsection{Yq11-PCR}

Die DNA, die vom jeweiligen Vater des betroffenen Kindes stammen sollte, wurde mit einer Multiplex-PCR vervielfältigt. Hierbei wurden eine weibliche und eine sog. Null-Kontrolle mitgeführt. Dafür wurden Primer benutzt, die die Gene des Azoospermiebereichs b und c eingrenzen. Die Primer wurden dafür zum Multimix A mit $10 \mu$ Stammlösung je Primer mit $500 \mu \mathrm{l} \mathrm{H}_{2} \mathrm{O}$ gemixt. Die Reaktion erfolgte nach diesem Ansatz $(25 \mu \mathrm{l})$ :

Multiplex PCR Kit

Multimix A

Template

$\mathrm{H}_{2} \mathrm{O}$

PCR-Programm: $\quad 95^{\circ} \mathrm{C}$

$$
97^{\circ} \mathrm{C}
$$

$60^{\circ} \mathrm{C}$

$72^{\circ} \mathrm{C}$

$72^{\circ} \mathrm{C}$
$12,5 \mu \mathrm{l}$

$2,5 \mu \mathrm{l}$

$1,0 \mu \mathrm{l}$

$9 \mu \mathrm{l}$

$15 \mathrm{~min}$

$30 \mathrm{sec}$

$1 \mathrm{~min}$

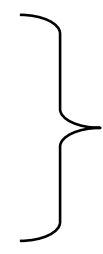

30 Zyklen

Im Anschluss erfolgte die Auftrennung der PCR-Produkte auf einem $2 \%$ igen Agarosegel. Über die Fotodokumentation erfolgte die Auswertung, wie beispielhaft Abbildung 3.1 zeigt. Die weibliche Kontrolle zeigt keine Bande, weil der sog. Azoospermiefaktor auf dem yChromosom lokalisiert ist. Die männliche Nullkontrolle zeigt das Vorhandensein der PCRProdukte des Azoospermiebereichs $b$ und $c$ an. Die nachfolgend aufgetragenen PCRProdukte [3-12] zeigen auch das Vorhandensein des Azoospermiebereichs b und c, sodass bewiesen wurde, dass die jeweilige Probe vom männlichen Elternteil des betroffenen Kindes stammt. 


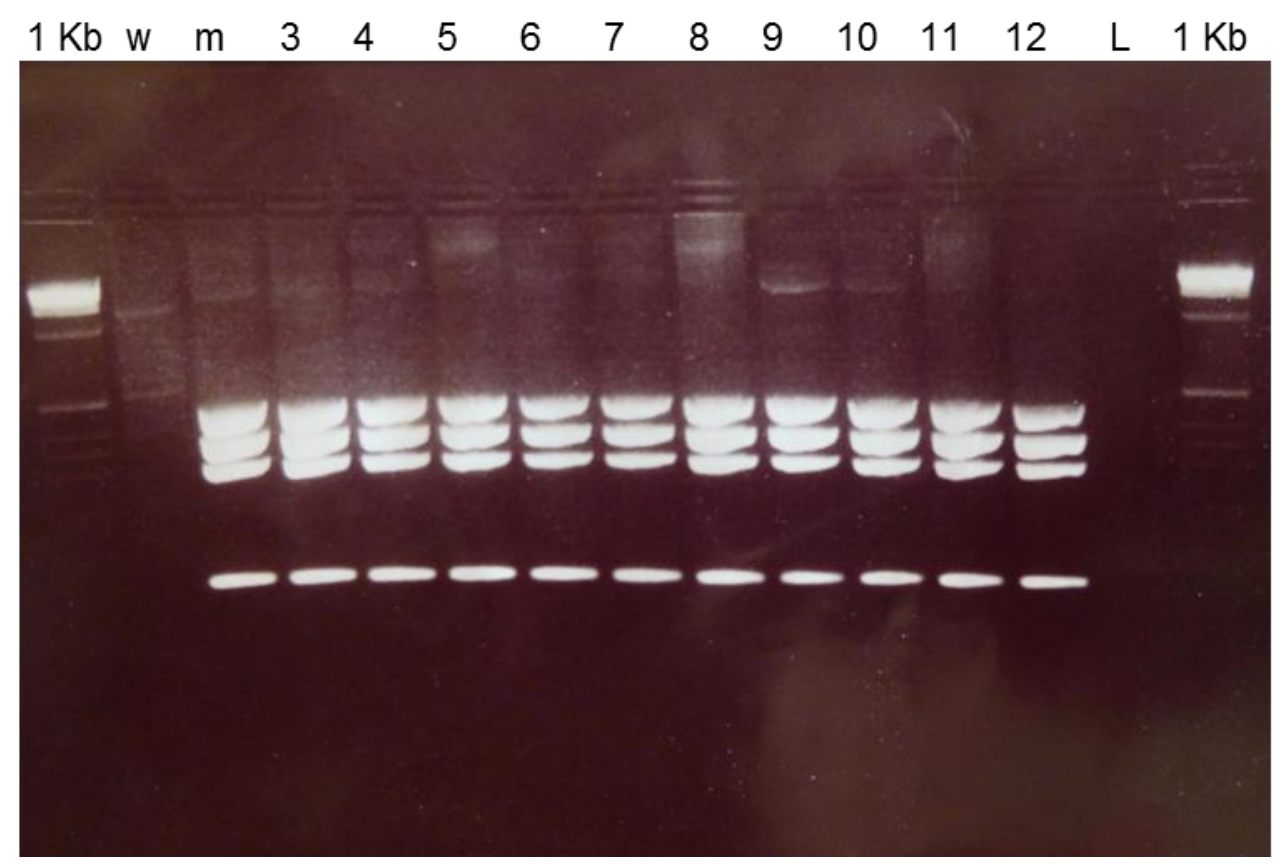

Abb. 3.1: Auszug der Yq11-PCR-Produkte: $[\mathrm{w}]$ weibliche Kontrolle, $[\mathrm{m}]$ männliche Nullkontrolle, [L] Negativkontrolle, [3-12] PCR-Produkte des jeweiligen Vaters des betroffenen Kindes. Die männliche Nullkontrolle [m] zeigt das Vorhandensein der PCR-Produkte des Azoospermiebereichs $b$ und $c$ an. Die PCR-Produkte [3-12] zeigen, dass die jeweilige Probe männlichen Ursprungs ist. Die weibliche Kontrolle $[w]$ zeigt keine Bande, da der sog. Azoospermiefaktor auf dem y-Chromosom lokalisiert ist. 


\section{ERGEBNISSE}

\subsection{Patientenkollektive}

Die Proben der untersuchten Patienten stammen von der Universitätsklinik Göttingen, auswärtigen Kliniken und Praxen sowie Fachärzten für Humangenetik. Sowohl für das Kandidatenscreening als auch für die Haplotypanalyse liegen genehmigte Ethikanträge vor (Antrags-Nr.: 22/02/09 und 15/04/09).

Für die Beschreibung der Mutationen und der Polymorphismen wurde die Schreibweise nach Den Dunnen und Antonarakis (2000) verwendet und die aktuellen Leitlinien der HGVS (s. 2.1.14) berücksichtigt.

\subsection{Patientenkollektive für Kandidatengenscreening}

Im Rahmen dieser Arbeit wurden 25 Patienten mit der klinischen Verdachtsdiagnose eines CHARGE-Syndroms molekulargenetisch untersucht. Im Vorfeld wurde bei diesen Patienten molekulargenetisch durch Sequenzierung und Deletionsanalyse mittels MLPA eine Mutation im CHD7-Gen ausgeschlossen.

\subsubsection{Kandidatengen $\mathrm{CHD8}$}

Es konnte von unserer Arbeitsgruppe gezeigt werden, dass CHD8 ein Interaktionspartner von CHD7 ist. Da Interaktionspartner des CHD7-Proteins im mutierten Zustand möglicherweise an der Pathogenese des CHARGE-Syndroms beteiligt sind, wurden 25 CHD7-negative CHARGE-Patienten auf Mutationen im CHD8-Gen untersucht. Für die Etablierung der CHD8-Diagnostik wurden für den kodierenden Bereich des CHD8-Gens 38 Primerpaare erstellt(s. 2.1.13.1). Für größere Exons wie Exon 4, 32 und 38 mussten dabei 2 Primerpaare hergestellt werden. Eng zusammenliegende Exons wie z. B. Exon 24 und 25 oder 29 und 30 konnten in einem Produkt zusammengefasst werden. Die aus Lymphozyten gewonnene DNA wurde mit Immolase in einem Touchdown-60 ${ }^{\circ} \mathrm{C}$-Programm amplifiziert (s. 2.2.6). Nach der Aufreinigung auf Nucleo-Fast-Platten (s. 2.2.13.2) erfolgte die SequenzPCR und danach die Sequenzierung der PCR-Produkte (s. 2.2.17, 2.2.18). Die Abbildung 3.2 zeigt exemplarisch PCR-Produkte des CHD8- Screenings auf einem $1 \%$ igem Agarosegel. 


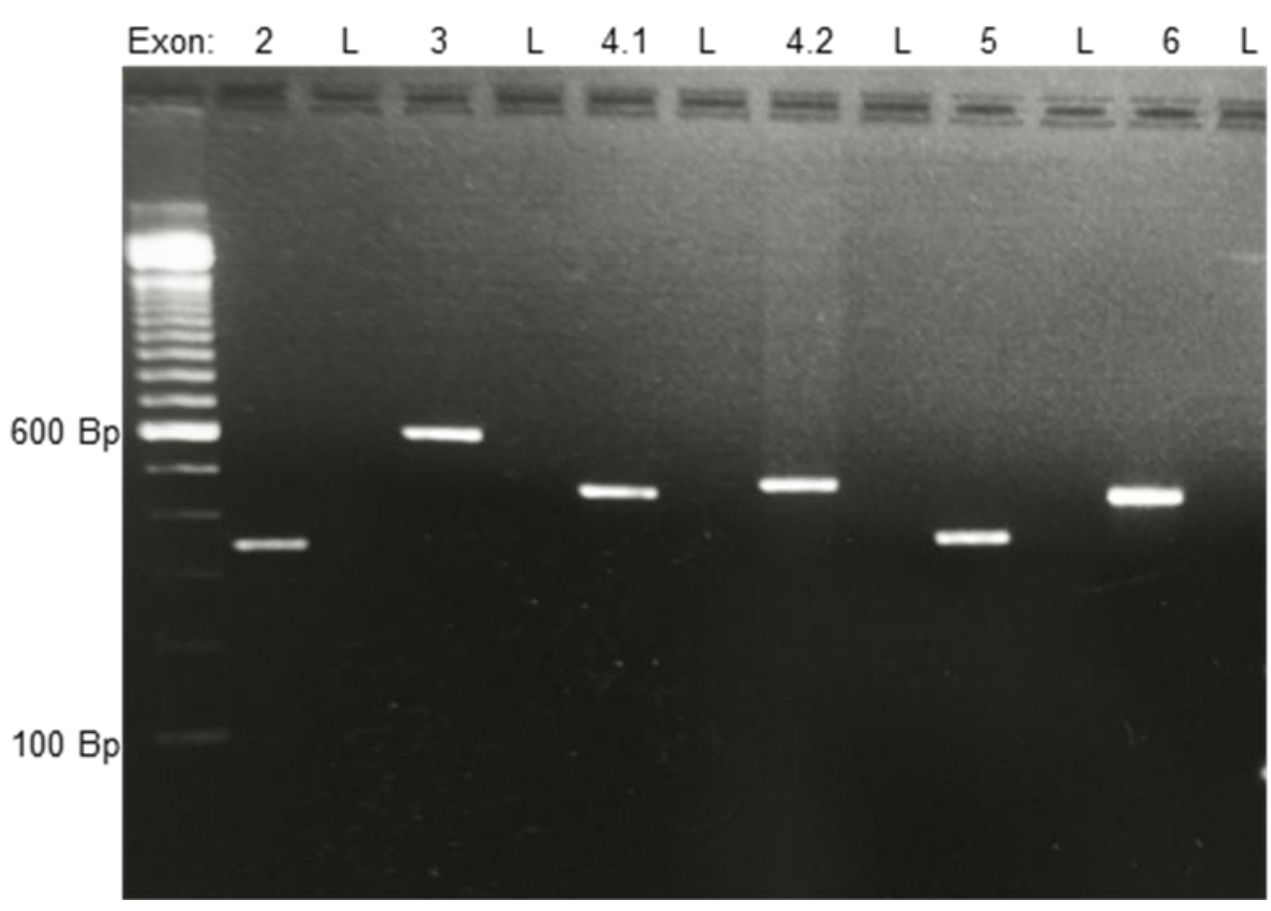

Abb. 3.2: $C H D 8$-Screening-Auszug eines $1 \%$ igen Agarosegels: Es wurde neben dem jeweiligen PCR-Produkt eine Negativkontrolle (L) aufgetragen. Exemplarisch sind hier die PCR-Produkte von Exon 2 bis Exon 6 aufgetragen.

In keiner der 25 untersuchten Familien konnte eine pathogene Mutation durch Sequenzanalyse im kodierenden Bereich oder angrenzenden Intronbereich im CHD8-Gen entdeckt und verifiziert werden. 


\subsubsection{Kandidatengen FAM124B}

Als zweiter Interaktionspartner des CHD7-Proteins wurde in unserer Arbeitsgruppe FAM124B identifiziert. Zunächst wurde für FAM124B eine genaue Transkriptuntersuchung durchgeführt, da zwischen der Datenbank ENSEMBL und NCBI Diskrepanzen bezüglich der Anzahl der Isoformen beim Menschen vorliegen. Dafür wurde zunächst cDNA aus RNA, die aus menschlichem Blut unter Verwendung des PEQLAB Total RNA Kit gewonnen wurde, hergestellt (s. 2.2.3, 2.2.9). Für die Amplifizierung des 1806 Bp langen Produktes wurde das Primerpaar Fam124BHu RT-F/R (s. 2.1.13.4) verwendet. Nachdem sich eine nur schwache Expression im humanen Blut zeigte, wurde die Analyse an kommerziell erhältlicher cDNA aus menschlichem Gehirn durchgeführt. Es konnte gezeigt werden, dass dort zwei Isoformen exprimiert werden (vgl. Abbildung 3.3). Der kodierende Bereich der Isoform A ist $1368 \mathrm{Bp}$, derjenige der Isoform B 819 Bp groß. Die Splice-sites des Exons 2 folgen nicht der AG-GTRegel, sondern der seltener vorkommenden AG-GC-Regel.

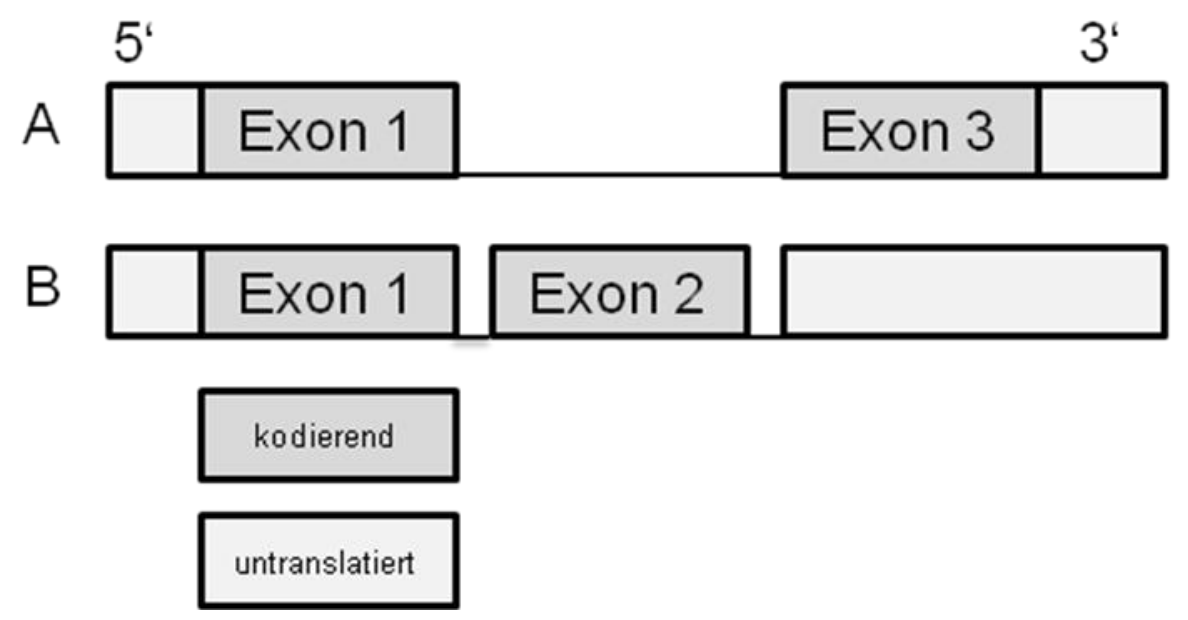

Abb. 3.3: FAM124B Isoformen beim Menschen

Ferner wurde die Expression von Fam124B in murinem Gewebe untersucht. Bei der Maus wird in den Datenbanken nur ein Transkript, bestehend aus zwei Exons, beschrieben. Aus verschiedenen Organen wurde RNA isoliert (s. 2.2.4). Mittels RT-PCR (s. 2.2.9) konnte die Expression in Gehirn, Herz, Niere, Lunge, Milz und Hoden nachgewiesen werden (s. Abbildung 3.4). Das murine Transkript entspricht weitgehend der Isoform A beim Menschen. 


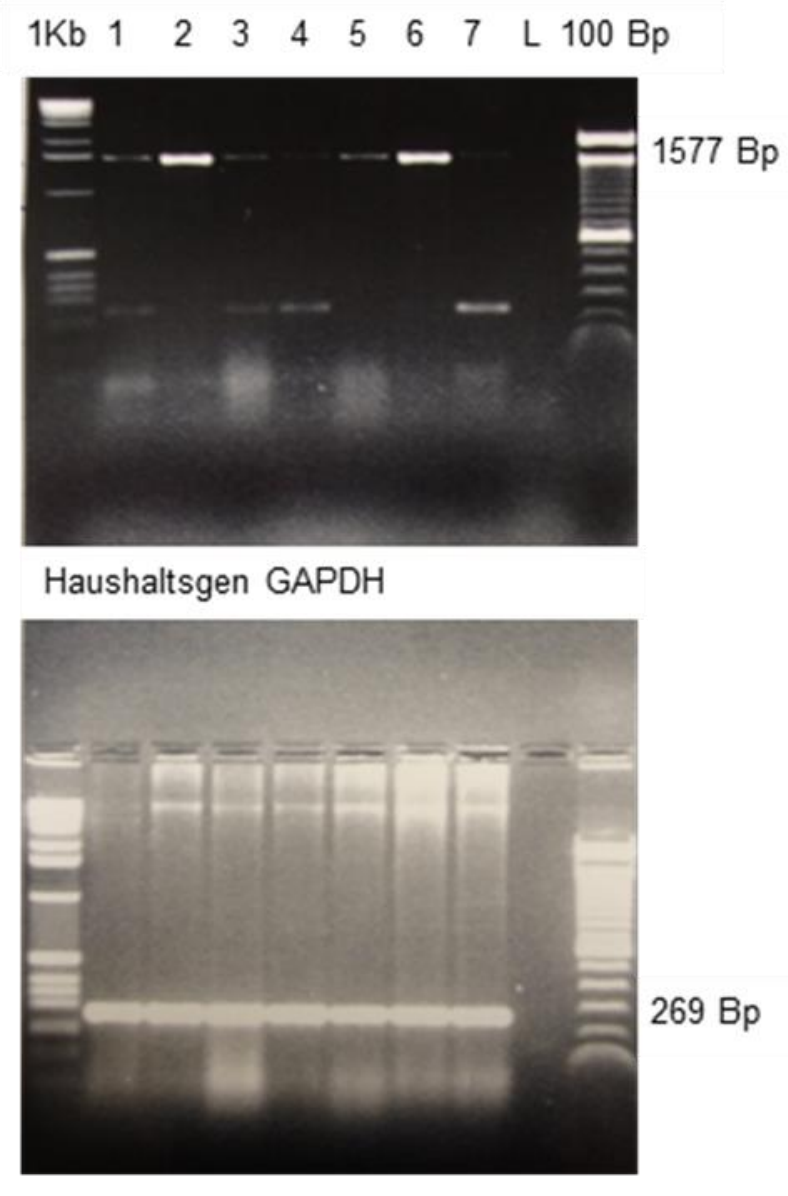

Abb. 3.4: RT-PCR-Produkte von Fam124B bei der Maus: [1] Gehirn, [2] Herz, [3] Niere, [4] Leber, [5] Lunge, [6] Milz, [7] Hoden, [L] Negativkontrolle: Die sichtbare Bande bei $1577 \mathrm{Bp}$ zeigt an, dass Fam124B jeweils im murinen Gewebe exprimiert wird. Das Haushaltsgen GAPDH ist ein nicht reguliertes Gen, welches ein Enzym der Glykolyse kodiert. Es ist unabhängig von Zelltyp und Zellstadium und diente als Nachweis für das erfolgreiche Umschreiben der RNA in cDNA.

Für das Kandidatengenscreening wurden zunächst 8 Primerpaare (s. 2.1.13.2) erstellt, um den kodierenden Bereich des Gens abzudecken. Die PCR-Produkte waren zwischen 585849 Bp lang. Nach der Etablierung am Wildtyp wurden insgesamt Proben von 26 CHARGEPatienten, bei denen keine Mutation im CHD7-Gen detektiert werden konnte, auf Mutationen im FAM124B-Gen untersucht. Dafür wurden die DNA-Proben mit Immolase im Touchdown$60{ }^{\circ} \mathrm{C}$-Programm amplifiziert und nach Aufreinigung mit Nucleo-Fast-Platten sequenziert (s. 2.2.6, 2.2.13.2, 2.2.17, 2.2.18).

Ergänzend wurden auch zwei Patienten mit Verdacht auf ein Goldenhar-Syndrom, ein angeborenes Fehlbildungssyndrom, das u. a. durch Missbildungen im Gesichtsbereich wie Hypoplasie der Mandibula oder Maxilla, Mikrotie mit präaurikulären Anhängseln, Anophthalmie, aber auch Fehlbildungen an Nieren oder am Herzen gekennzeichnet sein kann, untersucht. Mit zusätzlichen PCR-Produkten mithilfe weiterer Primer wie FAM124B 
Ex1.1gR zusammen mit FAM124B Ex1.2F (s. 2.1.13.2) konnten auffällige Stellen abgeklärt werden. Bei keinem Patienten konnte eine pathogene Mutation in den kodierenden Bereichen und in angrenzenden Intronbereichen gefunden werden. Ein CHARGE-Patient und die zwei Goldenhar-Patienten zeigten einen Basenaustausch im Exon 3 an der Position c.612 von Cytosin nach Thymin (c.612C>T) (vgl. Abbildung 3.5). Diese Veränderung führt zu einem Aminosäurenaustausch von Leucin zu Phenylalanin (p.L204F). Das entsprechende PCR-Produkt mit einer Länge von 799 Bp war mit den Primern FAM124B Ex 3.1F/R amplifiziert worden.
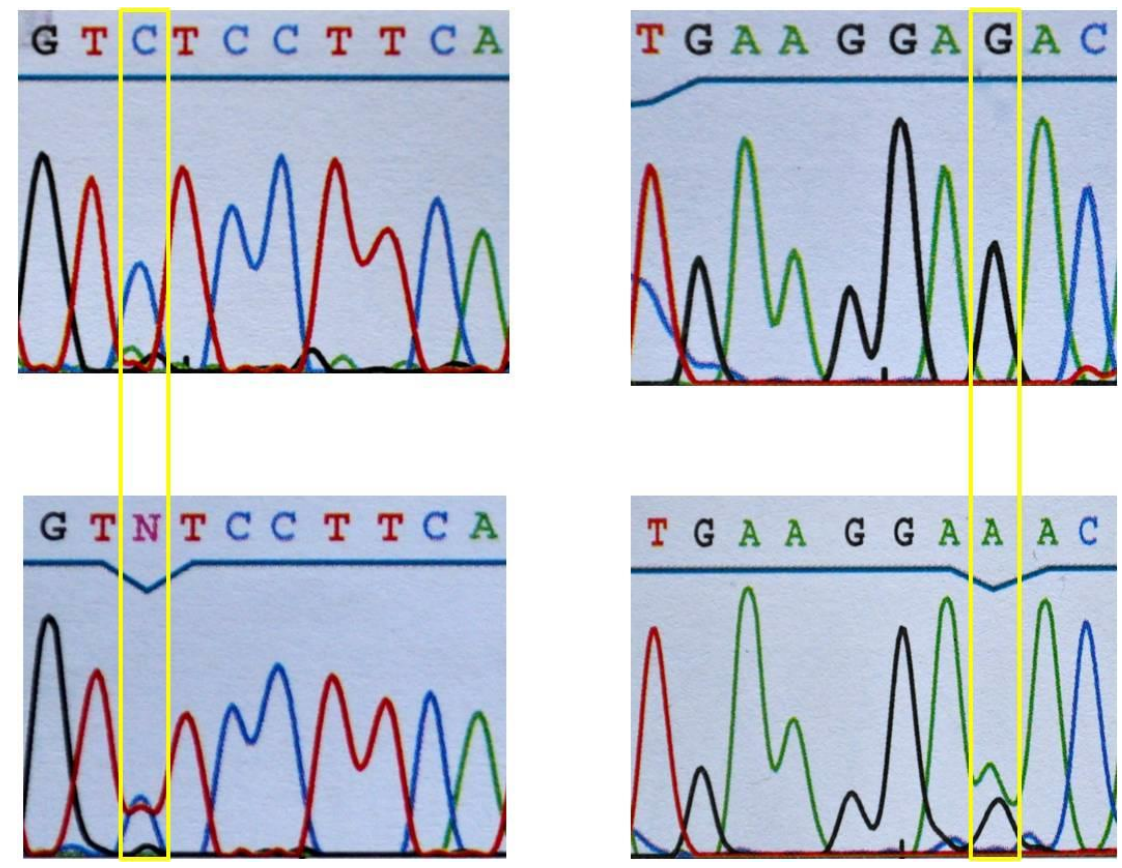

Abb. 3.5: Sequenzdarstellung des Produktes FAM124B Ex.3.1: links: DNA-Sequenz mit Primer FAM124B Ex.3.1F sequenziert, oben: Wildtyp, unten: SNP c.612C>T, rechts: DNA-Sequenz mit Primer FAM124B Ex 3.1R sequenziert, oben: Wildtyp, unten SNP c.612C>T, gelb markiert ist die Stelle c.612C>T.

Zum Ausschluss eines Amplifikationsfehlers der Polymerase während der PCR wurde mit demselben Primerpaar erneut das entsprechende PCR-Produkt hergestellt und sequenziert. Zusätzlich wurde für einen Restriktionsverdau (s. 2.2.10) ein kürzeres PCR-Produkt mit einer Länge von $173 \mathrm{Bp}$ mithilfe der Primer FAM124B Ex3.2F und Ex3.1R mit Immolase hergestellt. Das verwendete Restriktionsenzym BsmA1 schneidet die Wildtyp-Sequenz in ein $136 \mathrm{Bp}$ und $37 \mathrm{Bp}$ großes Fragment. Im Falle der o. g. Mutation wird das Produkt nicht geschnitten. Das PCR-Produkt eines Patienten sowie das gleiche Produkt einer WildtypKontrolle wurden mit dem Restriktionsenzym über $6 \mathrm{~h}$ bei $37^{\circ} \mathrm{C}$ inkubiert und danach auf ein 
$3 \%$ LMP (low melting point)-Agarosegel aufgetragen. Es war sowohl die Bande des ungeschnittenen Produktes (173 Bp) als auch eine Bande mit einer Länge von $136 \mathrm{Bp}$ sichtbar. Die 3. Bande mit einer Länge von $36 \mathrm{Bp}$ konnte aufgrund der geringen Größe im Gel nicht nachgewiesen werden. Da bei den Patienten in der Sequenzierung der Basenaustausch im heterozygoten Zustand detektiert wurde, ist davon auszugehen, dass die Veränderung nur eines der beiden Allele betrifft. Die ungeschnittene Bande (173 Bp) weist auf das mutierte Allel hin, während die 136 Bp große Bande ein Schnittprodukt des WildtypAllels ist (s. Abbildung 3.6).
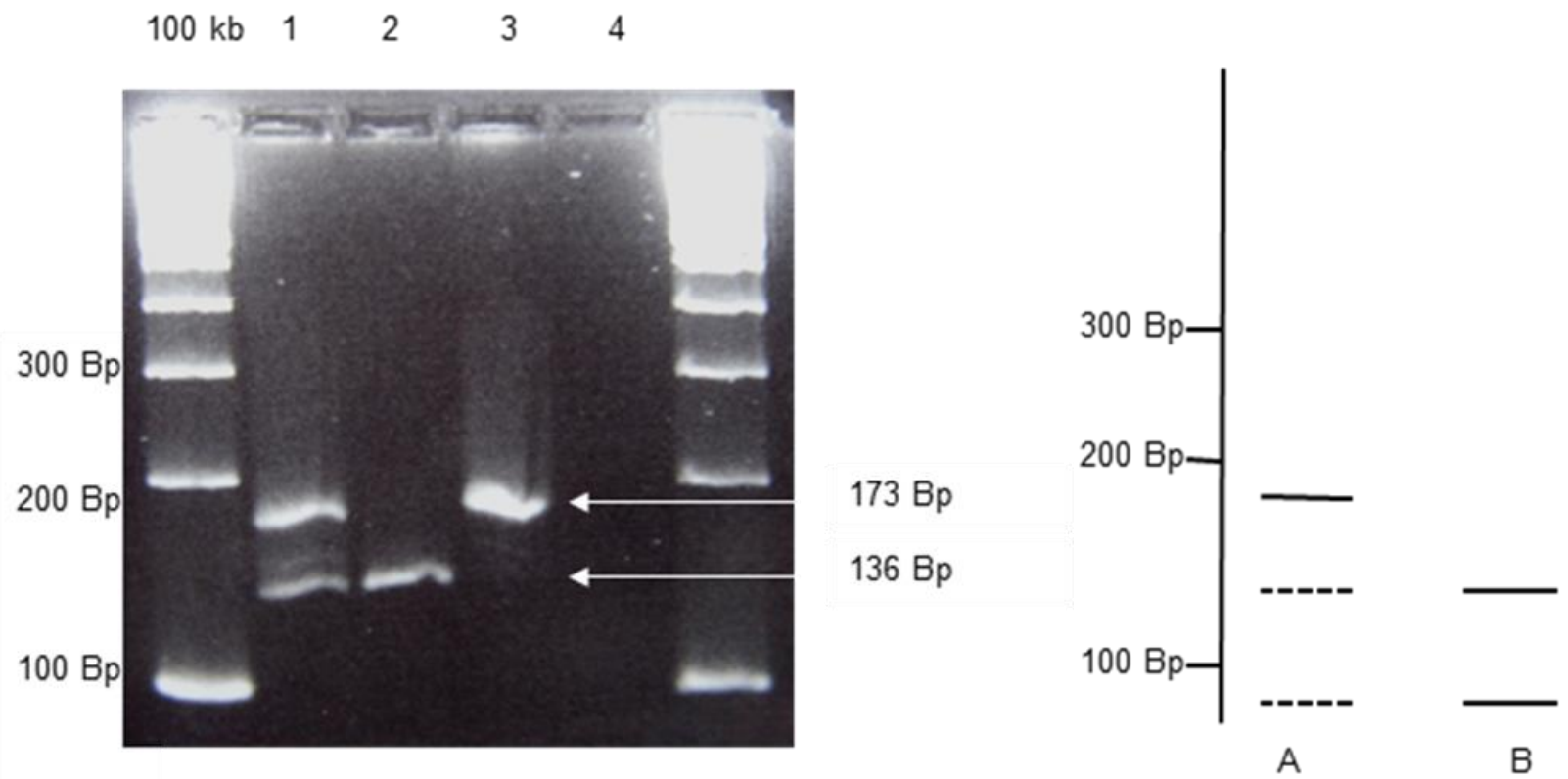

Abb. 3.6: Restriktionsverdau mit BsmA1: links: Agarosegel $2 \%$ : Restriktionsverdau mit BsmA1: [1] Verdau PCR-Produkt Patienten-DNA geschnitten, [2] Verdau PCR-Wildtyp-Produkt, [3] PCR-WildtypProdukt ungeschnitten, [4] Negativkontrolle; rechts: Schema des Restriktionsverdaus mit BsmA1: [A] Verdau bei Vorliegen einer heterozygoten Mutation, [B] Verdau bei Vorliegen von Wildtyp-Sequenz.

Da die DNA der Eltern in allen 3 Fällen nicht zur Verfügung stand, wurde zur weiteren Abklärung o. g. Auffälligkeit die DNA von 50 Wildtyp-Kontrollen untersucht, von denen 5 an der auffälligen Stelle auch heterozygot CT waren. Da folglich auch gesunde Personen die Veränderung aufweisen, kann davon ausgegangen werden, dass es sich bei der Veränderung um einen Polymorphismus handelt. Da Polymorphismen zwar keine direkte Krankheitsursache darstellen, aber als „Verstärker" einer bestehenden krankheitsverursachenden Mutation wirken können, wurden 21 CHARGE-Patienten mit Nachweis einer Mutation im CHD7-Gen auf das Vorliegen des Polymorphismus c.612C>T untersucht. 3 Patienten waren heterozygot für den Polymorphismus, während die restlichen Patienten homozygot das C-Allel aufwiesen. Diese Patienten mit der Heterozygotie in der 
genannten Position weisen Symptome wie Hörstörungen, Herzfehler, Kolobome, psychomotorische Entwicklungsretardierung und Lippen-Kiefer-Gaumenspalten auf. Unter den untersuchten Patienten mit CHD7-Mutation befand sich ein Geschwisterpaar, welches dieselbe Mutation c.7302dupA in Exon 34 aufweist, jedoch klinisch einen unterschiedlichen Phänotyp aufzeigt. Der Junge gehört zu den 3 Patienten, die heterozygot für den Polymorphismus sind, das Mädchen ist allerdings homozygot C (Wildtyp-Allel). Auch wenn sie unterschiedliche Symptome aufweisen, so sind klinisch beide schwer betroffen und es ist deshalb davon auszugehen, dass dieser neu entdeckte Polymorphismus keine Verstärkerfunktion einer krankheitsverursachenden Mutation beim CHARGE-Syndrom hat.

Weiterhin wurde durch die Sequenzanalyse der 21 CHARGE-Patienten, die eine Mutation im CHD7-Gen aufweisen, die Häufigkeit eines bereits bekannten Polymorphismus im FAM124BGen erfasst. In dem SNP rs 3738954 in Exon 3 sind 5 Patienten heterozygot TC. An dieser Stelle sind von den untersuchten Patienten ohne Mutation im CHD7-Gen 7 von 26 heterozygot TC; 17 der 50 Wildtyp-Kontrollen zeigen auch eine Heterozygotie. Es kann davon ausgegangen werden, dass der SNP keinen Einfluss auf den CHD7-Phänotyp hat, da klinisch kein Unterschied zwischen den heterozygoten Trägern des T-Allels als auch NichtTrägern zu bemerken ist. 


\subsection{Patientenkollektiv für Haplotypanalyse}

Es wurden 30 Patienten mit der Diagnose CHARGE-Syndrom untersucht. Im Vorfeld war jeweils bei diesen Patienten in der molekulargenetischen Diagnostik eine Mutation im CHD7Gen mittels Sequenzanalyse gefunden worden. Alle Mutationen liegen heterozygot vor, $d . h$. dass die jeweilige Veränderung nur ein Allel betrifft. Im Folgenden wurde die genomische Sequenz des CHD7-Gens ca. 2000 Bp vor der bekannten Mutation als auch ca. $2000 \mathrm{Bp}$ hinter der bekannten Mutation auf aussagekräftige Polymorphismen (SNP) untersucht. Ein aussagekräftiger SNP liegt z. B. bei folgender Konstellation vor: Die Mutter des betroffenen Kindes und das Kind selbst sind heterozygot CT in diesem SNP, der Vater hingegen TT. Somit kann angenommen werden, dass das Kind das C-Allel von der Mutter und das T-Allel vom Vater geerbt haben muss.

Bei Vorliegen eines aussagekräftigen SNP wurde die Vaterschaft anhand von Mikrosatelliten bestätigt (s. 2.2.19). Mittels Yq11-PCR (s. 2.2.20) wurde jeweils gezeigt, dass die väterliche Probe männlich ist. In der Regel wird diese Methode in der molekulargenetischen Diagnostik genutzt, um bei Männern Mikrodeletionen im Azoospermiebereich, welcher auf dem YChromosom liegt, nachzuweisen.

Die notwendigen PCR-Produkte wurden, wenn nicht anders angegeben, mit der Immolase DNA-Polymerase amplifiziert (s. 2.2.6). Bei Vorliegen eines aussagekräftigen SNP wurde ein PCR-Produkt hergestellt, welches sowohl die Mutation als auch den informativen SNP enthielt. Dieses diente gleichzeitig zur Bestätigung des SNP. Um festzustellen, welches Allel die Mutation betrifft, wurde einzelsträngige DNA benötigt. Dafür wurde das jeweilige PCRProdukt kloniert und in DH5a-Zellen transformiert (s. 2.2.14, 2.2.15). Einige der gewachsenen Kolonien, im Mittel zwischen 10-15, wurden, wenn nicht anders angegeben, mit der Polymerase Immolase amplifiziert und anschließend sequenziert. Anhand der einzelsträngigen DNA konnte nun ermittelt werden, welches Allel von der Mutation betroffen ist.

Im Folgenden werden nun die Ergebnisse der Familien vorgestellt: 


\subsubsection{Familien mit informativen Polymorphismen}

\section{Familie 1: Patientin 25648}
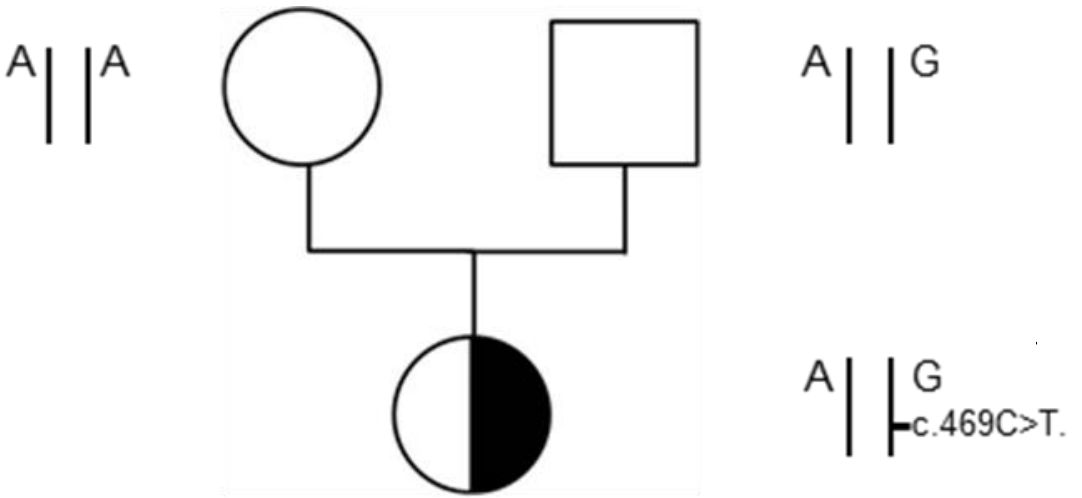

Abb. 3.7: Stammbaum Familie 1: Der Vater und das betroffene Kind sind heterozygot AG im SNP rs 7836586, die Mutter homozygot AA. Die kindliche Mutation im Exon 2, c.469C>T liegt auf dem G-Allel.

Beim betroffenen Kind ist die Mutation c.469C>T (p.R157X) in Exon 2 aus der vorausgegangenen molekulargenetischen Diagnostik bekannt. Der Austausch der Base Cytosin durch Thymin führt zum Aminosäurenaustausch von Arginin zu einem vorzeitigen Stopcodon an der Position 157. U. a. wurde mittels des Primerpaares CHD7 Diag Ex 2.5F/R nach informativen Polymorphismen gesucht. In den Sequenzen wurde ein aussagekräftiger SNP rs 7836586 gefunden. Der Vater und das Kind sind heterozygot AG, die Mutter hingegen homozygot AA. Daraus folgt, dass das G-Allel des Kindes vom Vater stammt. Daraufhin wurde ein neues PCR-Produkt (1475 Bp) mit dem Primerpaar SNP CHD7 E2-I2F/R und mit dem Expand Long Template PCR System (Roche Diagnostics, Mannheim) hergestellt, welches die Mutation sowie den entsprechenden Polymorphismus enthielt. Nach Ligation des PCR-Produktes in den pGEM-T easy Vector (Promega, Mannheim) und Klonierung in E.coli (s. 2.2.14, 2.2.15) wurde eine Colony-PCR mit dem Primerpaar SNP CHD7 E2-I2F/R durchgeführt. Das Ergebnis der Sequenzierung der Colony-PCR-Produkte zeigt Tabelle 3.1.

\begin{tabular}{|l|l|}
\hline 7 Klone Mutation & G im SNP \\
\hline 10 Klone Wildtyp & A im SNP \\
\hline 1 Klon Wildtyp & G im SNP \\
\hline 2 Mischklone & \\
\hline
\end{tabular}

Tab. 3.1: Ergebnis der Sequenzierung der Colony-PCR-Produkte der Patientin der Familie 1. 
Anhand dieses Ergebnisses konnte keine eindeutige Zuordnung zum paternalen oder maternalen Allel gemacht werden, obgleich aufgrund der Ergebnisse die Vermutung nahe liegt, dass die Mutation das G-Allel betrifft. Für die verschiedenen Kombinationen von Mutation und Wildtyp mit jeweils einem Allel des SNP wird das sog. Mega-Priming verantwortlich gemacht. In der Polymerase-Kettenreaktion wird der Komplementärstrang zu dem jeweiligen Strang gebildet. Es geschieht aber, dass die Polymerase aus verschiedenen Gründen die Amplifizierung abbricht, bevor der neue Strang komplett vorliegt. Das bis dahin vervielfältigte Stück wird in dem Reaktionsansatz nicht abgebaut. Es kann an den anderen Strang der DNA binden und dient dort der Polymerase als sog. Mega-Primer. Nun vollendet die Polymerase den begonnenen Strang, jedoch komplementär zum anderen Strang (s. Abbildung 3.8).

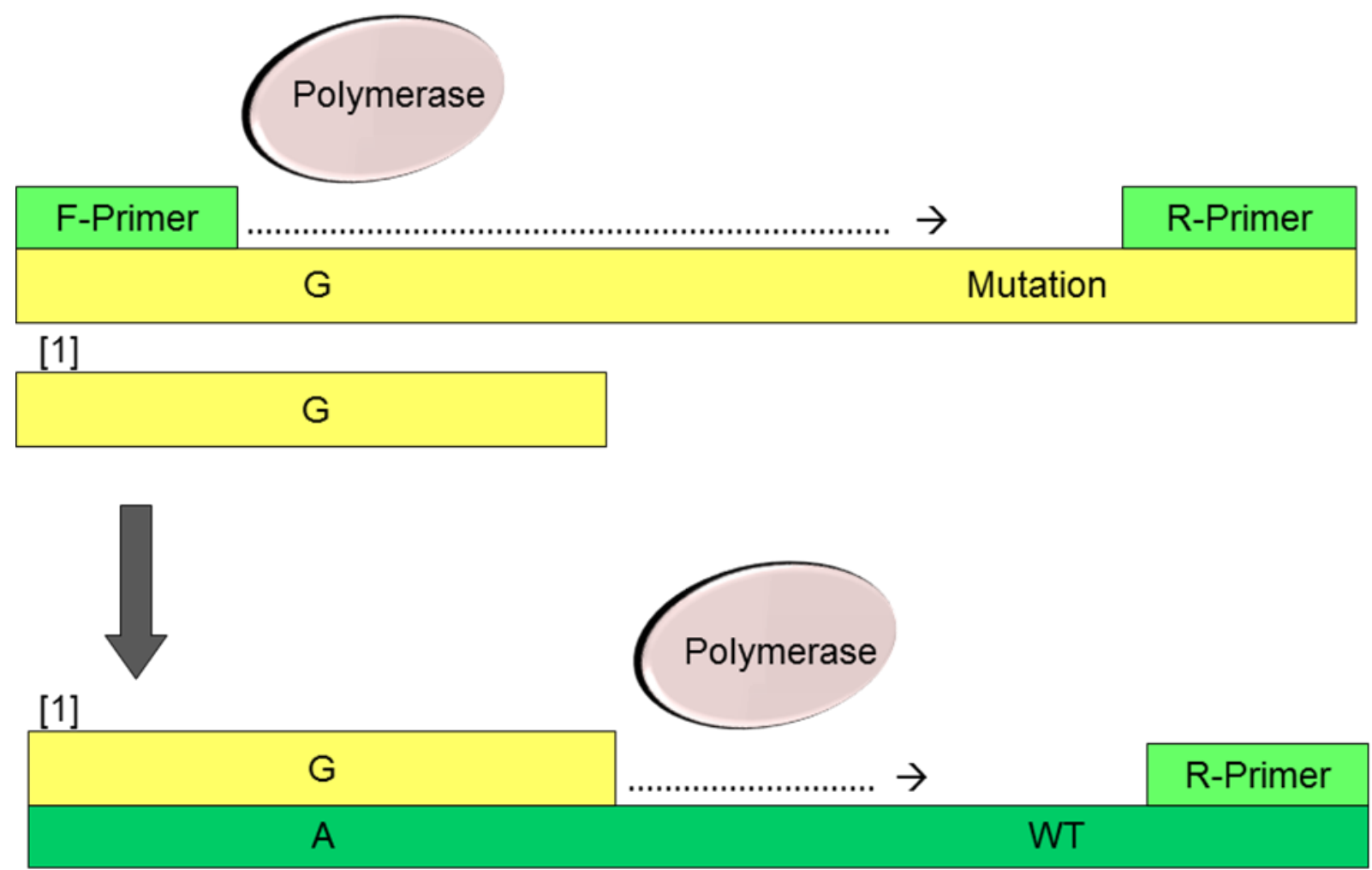

\section{G} WT

Abb. 3.8: Schema des Mega-Priming: Die Mutation liegt auf dem G-Allel. Die Polymerase beginnt mit der Amplifikation dieses Einzelstranges. Dabei bricht die Amplifikation nach einer gewissen Zeit unter Umständen ab; der bis dahin entstandene Strang kann im Anschluss als sog. Mega-Primer [1] dienen. Dieser Mega-Primer lagert an den anderen Strang an, d. h. an jenen mit dem A-Allel und der WildtypSequenz (WT). Die Polymerase setzt die Amplifikation fort, jedoch wird nun in den entstehenden Strang das Wildtyp-Allel anstatt des mutierten eingebaut. 
So geschieht es, dass die Mutation sowohl auf dem einen als auch auf dem anderen Allel liegen kann und eine Zuordnung zum paternalen oder maternalen Allel nicht mehr möglich ist. Daraufhin wurde nach 5'-3'-DNA-Polymerasen gesucht, die eine sog. ProofreadingAktivität besitzen, d. h. dass sie eine 3'-5'-Exonuklease-Aktivität haben und die Bruchstücke, die als Mega-Primer fungieren können, abbauen. In der Familie 1 wurden verschiedene Polymerasen getestet: Mit der Pfu (Promega, Mannheim) und dem LongRange PCR Kit (QIAGEN GmbH, Hilden) war es nicht möglich, das entsprechende PCR-Produkt herzustellen. Auch verschiedene Ansätze mit der Pwo SuperYield DNA-Polymerase (Roche Diagnostics, Mannheim) ließen keine adäquate PCR-Produktherstellung zu. Mit den Proofreading-Polymerasen Phusion (Finnzymes, Espoo, Finnland) und HotStar HiFidelity (QIAGEN GmbH, Hilden) konnte das entsprechende PCR-Produkt amplifiziert werden (s. 2.2.7.1, 2.2.7.2). Die Ergebnisse der Klonierung des PCR-Produktes mit der HotStar HiFidelity-DNA-Polymerase zeigt die Tabelle 3.2. Diese bestätigen die Vermutung, dass die Mutation bei dieser Patientin das paternale Allel betrifft.

\begin{tabular}{|l|l|}
\hline 6 Klone Mutation & G im SNP \\
\hline 2 Klone Wildtyp & A im SNP \\
\hline
\end{tabular}

Tab. 3.2: Ergebnisse der Sequenzierung der Colony-PCR-Produkte der Patientin 1. 


\section{Familie 2: Patientin 27436}

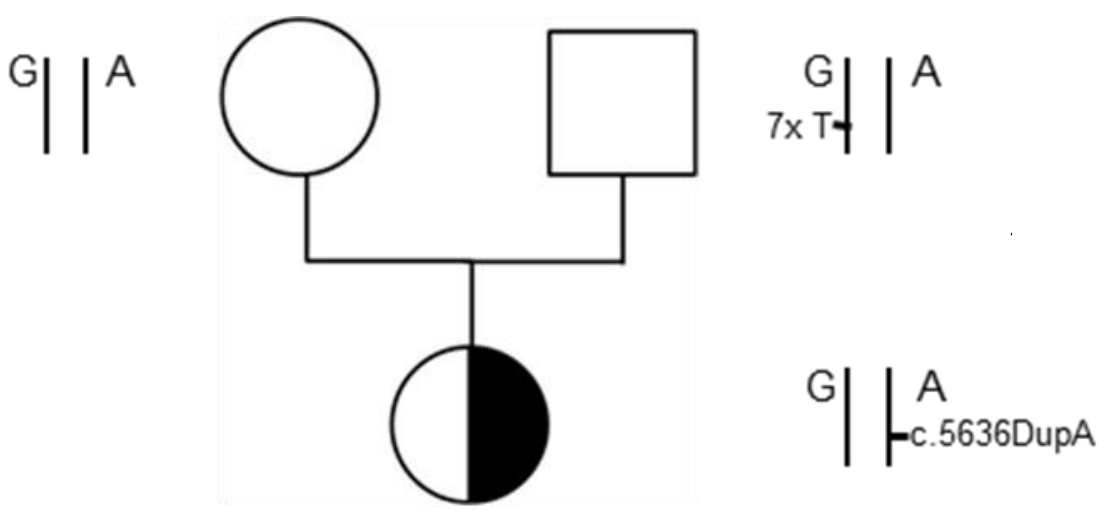

Abb. 3.9: Stammbaum Familie 2: Die Eltern und das Kind sind heterozygot GA im SNP rs 4342642. Der Vater weist eine Heterozygotie (6x T/ 7x T) in einer T-Box auf, in welcher die Mutter und das Kind homozygot für 6x T sind. Somit konnte der SNP für die Haplotypanalyse genutzt werden. Die kindliche Mutation c.5636dupA liegt auf dem A-Allel.

Die bei dieser Patientin bekannte Mutation im Exon 28, c.5636dupA konnte durch eine Amplifikation und Sequenzierung mit den Primern SNP CHD7 E28I28F/R (Produktgröße 617 Bp) bestätigt werden. In der Familie 2 konnten für die Haplotypanalyse ein zunächst nicht informativer SNP rs 4342642 und zusätzlich eine Veränderung in der Anzahl von ThyminBasen in der nahe gelegenen T-Box beim Vater verwendet werden. An der Position des SNPs rs 4342642 sind beide Elternteile als auch das betroffene Kind heterozygot GA. 188 Basen downstream des SNPs befindet sich eine T-Box, in der beim Vater eine unterschiedliche Anzahl an Thymin-Basen vorliegt. Die Heterozygotie in der T-Box zeigte sich beim Vater in Form einer Verschiebung des Leserahmens (Frameshift) (s. Abbildung 3.10). 

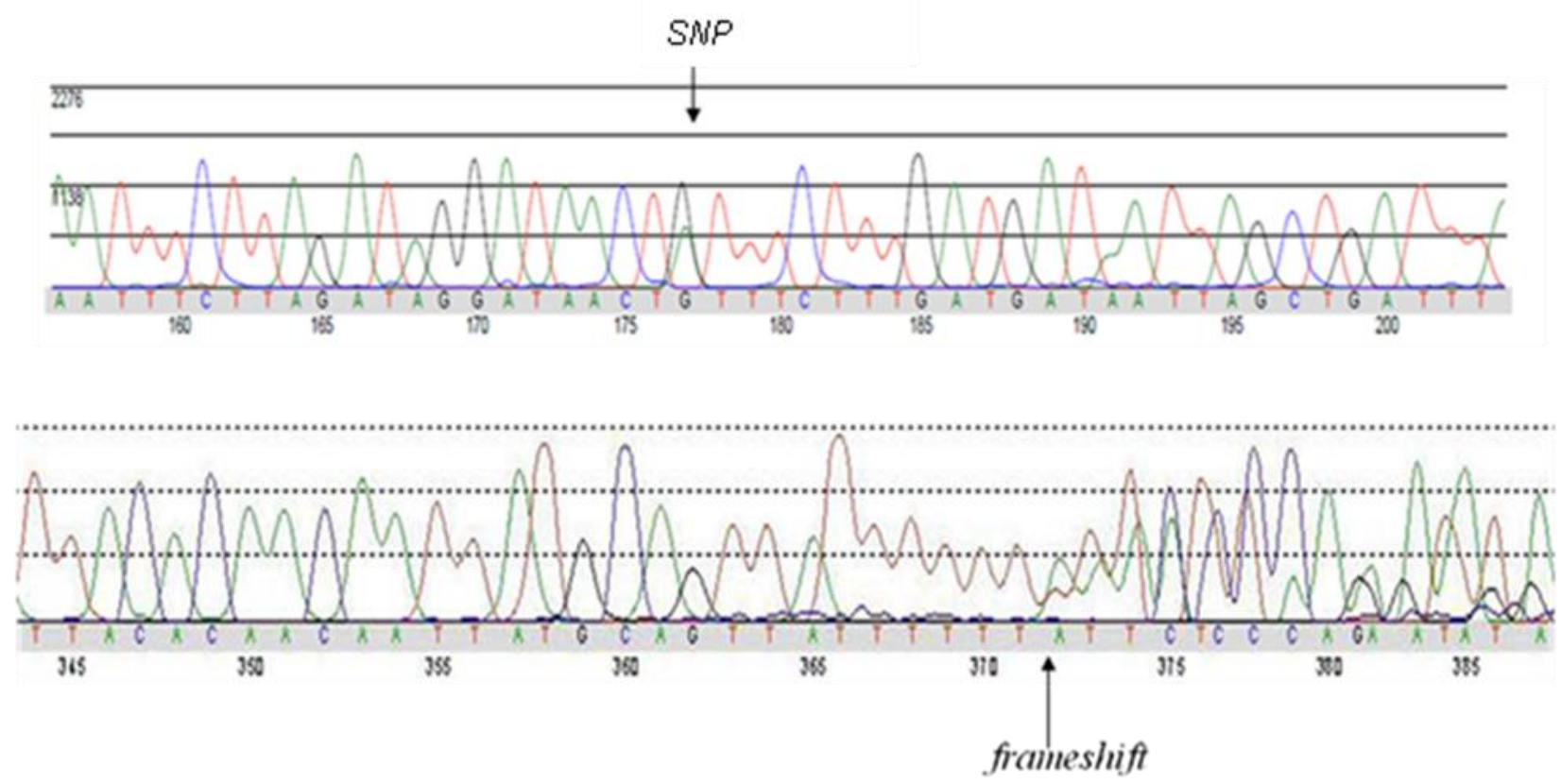

Abb. 3.10: Sequenzauszug mit dem Primer SNP CHD7 E28I28F der väterlichen DNA: In der Sequenz ist der verwendete SNP rs 4342642 und die Heterozygotie in der T-Box und folglich die entstehende Leserasterverschiebung zu erkennen.

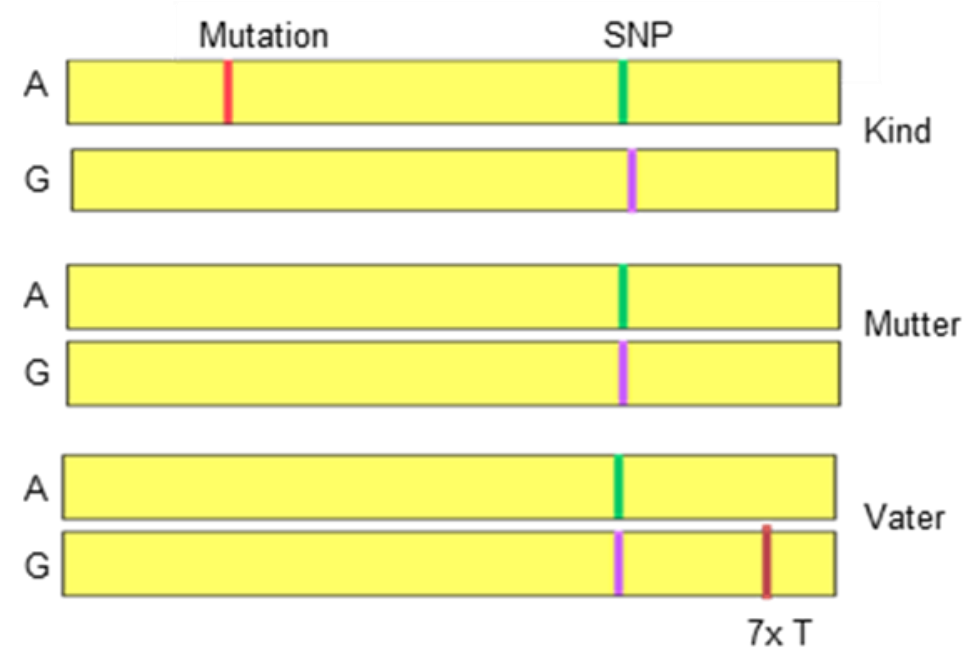

Abb. 3.11: Grafische Darstellung der Allelzuordung in Familie 2.

So wurde zunächst ein PCR-Produkt der väterlichen DNA hergestellt, welches den nichtinformativen SNP rs 4342642 und die T-Box enthielt. Dieses PCR-Produkt wurde kloniert und sequenziert. Es zeigte sich, dass 7 Klone 7x T und G im SNP rs 4342642 und dass 12 Klone 6x T und A im SNP rs 4342642 aufweisen. Daher konnte davon ausgegangen werden, dass beim Vater das A-Allel in der T-Box 6 Thymine aufweist und das G-Allel 7. Da das Kind 
in der T-Box aber homozygot für 6x $\mathrm{T}$ ist, konnte man sicher annehmen, dass das Kind das A-Allel vom Vater und das G-Allel von der Mutter geerbt haben muss. Die Sequenzen der Colony-PCR der kindlichen DNA ergaben eine Zuordnung zum väterlichen Allel (s. Tabelle 3.3).

\begin{tabular}{|l|l|}
\hline 10 Klone Mutation & A im SNP \\
\hline 7 Klone Wildtyp & G im SNP \\
\hline 3 Mischklone & \\
\hline
\end{tabular}

Tab. 3.3: Auswertung der Sequenzen der Colony-PCR-Produkte der Patientin 2. 


\section{Familie 3: Patient 2129-1}
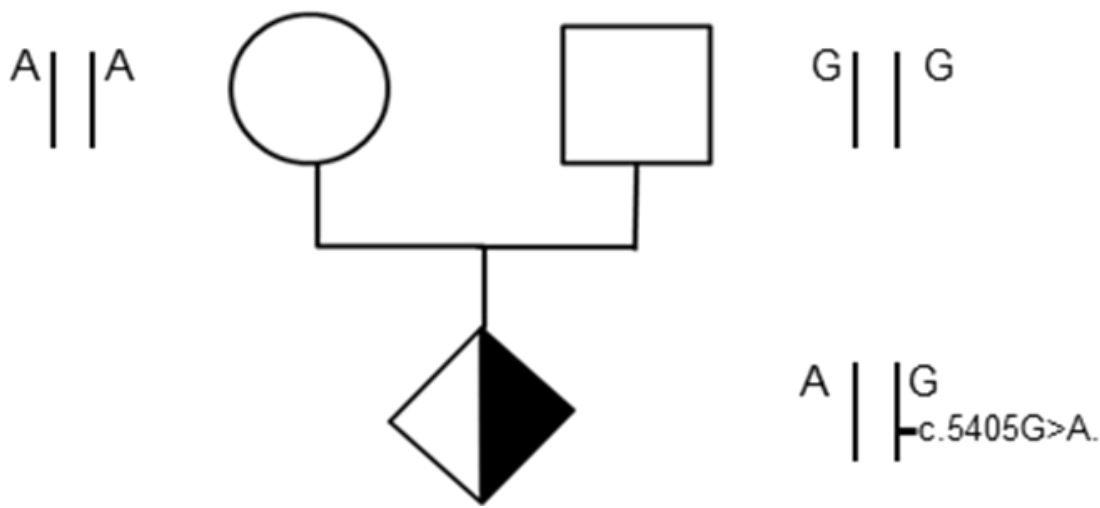

Abb. 3.12: Stammbaum Familie 3: Der SNP rs 4342642 ist informativ: Die Mutter ist homozygot AA, der Vater homozygot GG, das Kind heterozygot AG. Die Mutation beim Kind in Exon 26, c.5405G>A (p.G1802D) liegt auf dem G-Allel.

Bei diesem Patienten liegt in Exon 26 die Mutation c.5405G>A (p.G1802D) vor. Der Basenaustausch von Guanin durch Adenin führt zu einem Aminosäurenaustausch von Glycin zu Asparaginsäure an der Position 1802. Mit der HotStar HiFidelity-DNA-Polymerase wurde sowohl ein PCR-Produkt mit dem Primerpaar SNP CHD7 I25-26F/R mit einer Größe von $1486 \mathrm{Bp}$ als auch ein Produkt mit dem Primerpaar SNP CHD7 127-28F/R mit einer Produktlänge von 858 Bp hergestellt. Der SNP rs 4342642 war aussagekräftig und konnte für die Zuordnung zum väterlichen oder mütterlichen Allel genutzt werden. Für die Klonierung wurde ein PCR-Produkt mit einer Länge von $1221 \mathrm{Bp}$ mit dem Primerpaar SNP CHD7 E26I28F/R hergestellt und kloniert. In Tabelle 3.4 ist das Ergebnis der Sequenzierung von 12 Klonen angegeben. Die Mutation c.5405G>A betrifft das paternale Allel.

\begin{tabular}{|l|l|}
\hline 4 Klone Mutation & G im SNP \\
\hline 7 Klone Wildtyp & A im SNP \\
\hline 1 Mischklon & \\
\hline
\end{tabular}

Tab. 3.4: Ergebnis der Sequenzierung der Colony-PCR-Produkte des Patienten 3. 


\section{Familie 4: Patient 1209-1}
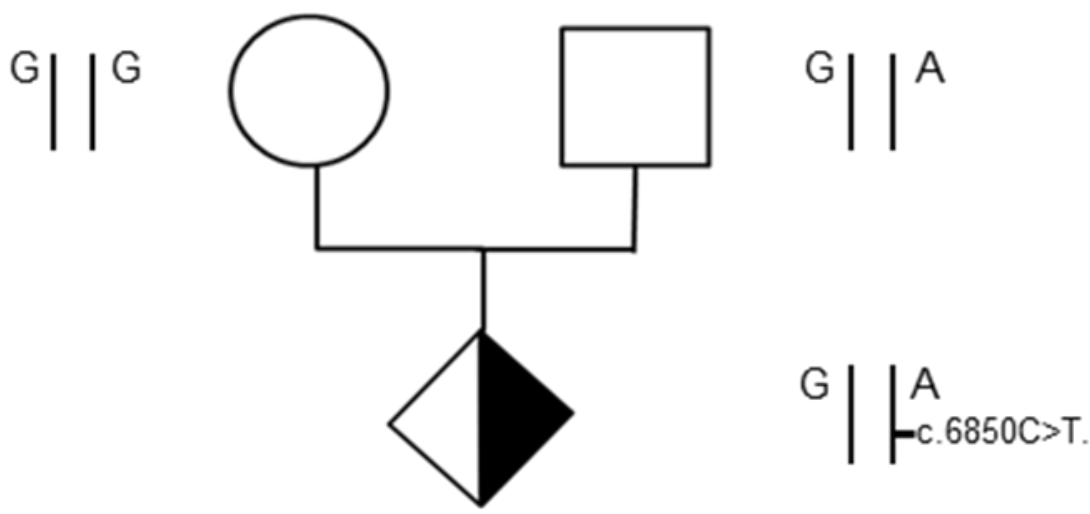

Abb. 3.13: Stammbaum Familie 4: Der Vater und das Kind sind heterozygot GA im SNP rs 61733338, die Mutter homozygot GG. Die Mutation im Exon 32, c.6850C>T liegt auf dem A-Allel.

Die zuvor detektierte Mutation c.6850C > T in Exon 32 beim betroffenen Kind konnte mittels erneuter PCR bestätigt werden. Von der elterlichen und kindlichen DNA wurde mit der DNAPolymerase HotStar HiFidelity neben einem PCR-Produkt mit den Primerpaar SNP CHD7 I31F/R auch ein Produkt mit dem Primer CHD7 Diag Ex32F zusammen mit SNP CHD7 Ex32R-Primer erzeugt. Der SNP rs 61733338 war aussagekräftig, weil der Vater und das Kind heterozygot AG, die Mutter hingegen homozygot GG ist. Das Ergebnis der Sequenzierung der Klone zeigt Tabelle 3.5.

\begin{tabular}{|l|l|}
\hline 2 Klone Mutation & G im SNP \\
\hline 1 Klon Wildtyp & G im SNP \\
\hline 5 Mischklone & \\
\hline
\end{tabular}

Tab. 3.5: Ergebnis der Sequenzierung der Colony-PCR-Produkte des Patienten 4.

Es wurde ein neues PCR-Produkt mit der HotStar HiFidelity-DNA-Polymerase erzeugt, mit dem Ergebnis, welches in Tabelle 3.6 dargestellt ist. 


\begin{tabular}{|l|l|}
\hline 3 Klone Mutation & A im SNP \\
\hline 3 Klone Mutation & G im SNP \\
\hline 6 Klone Wildtyp & G im SNP \\
\hline 2 Klone Wildtyp & A im SNP \\
\hline
\end{tabular}

Tab. 3.6: Ergebnis der Sequenzierung der Colony-PCR-Produkte des Patienten 4. Das Ausgangsprodukt wurde mit der HotStar HiFidelity-DNA-Polymerase hergestellt.

Trotz der Verwendung der Proofreading-Polymerase tauchten in den Sequenzen der ColonyPCR erneut verschiedene Kombinationen von Mutation, Wildtyp und G- oder A-Allel auf. Nach Information des Herstellers QIAGEN GmbH ist der HotStar HiFidelity-DNA-Polymerase zur besseren Amplifikation ein sehr geringer Anteil an einer Taq-Polymerase zugesetzt, sodass das sog. Mega-Priming nicht vollständig durch die Proofreading-Polymerase unterbunden werden kann. So wurde eine andere Proofreading-Polymerase, die peqGOLD Pwo-DNA-Polymerase, für die Herstellung eines neuen PCR-Produktes gewählt. Die Ergebnisse der Klonierung dieses Produktes ergaben, dass die Mutation auf dem väterlichen Allel liegt (s. Tabelle 3.7).

\begin{tabular}{|l|l|}
\hline 8 Klone Mutation & A im SNP \\
\hline 7 Klone Wildtyp & G im SNP \\
\hline 5 Mischklone & \\
\hline
\end{tabular}

Tab. 3.7: Ergebnis der Sequenzierung der Colony-PCR-Produkte des Patienten 4. Das AusgangsPCR-Produkt wurde mit der peqGOLD Pwo-DNA-Polymerase erzeugt. 


\section{Familie 5: Patient 1065-1}

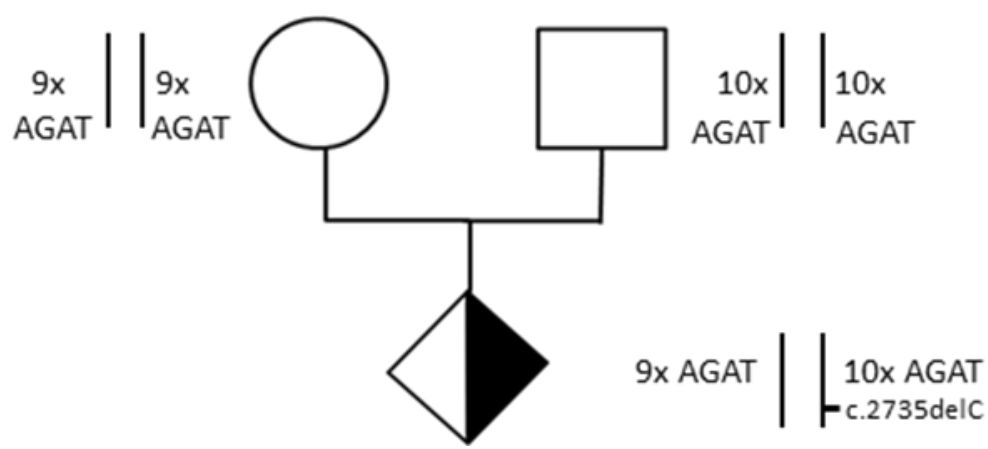

Abb. 3.14: Stammbaum Familie 5: Im SNP rs 59147613 ist der Vater homozygot für 10x AGAT und die Mutter homozygot für 9x AGAT, das Kind ist heterozygot 9x AGAT/ 10x AGAT. Die Mutation c.2735delC im Exon 10 liegt auf dem Allel mit 10x AGAT-Wiederholungen. [9x bzw.10x AGAT]: $9 x$ bzw. 10x AGAT-Wiederholungen.

Der Patient weist im Exon 10 heterozygot eine Deletion der Base Cytosin an der Position c.2735 (c.2735delC) auf. Mithilfe der Primer SNP CHD7 I9-I11F/R und SNP CHD7 I12F/R wurden Bereiche von Intron 9 bis Intron 12 auf aussagekräftige SNPs untersucht. Der SNP rs 59147613 konnte für die Haplotypanalyse angewandt werden. Der Vater ist homozygot für 10x AGAT, die Mutter für 9x AGAT, das Kind ist heterozygot. Mit den Primern CHD7 Diag 10F und SNP CHD7 In 12.3R wurde ein neues PCR-Produkt mit einer Größe von 1853 Bp mit der peqGOLD Pwo-DNA-Polymerase hergestellt, welches die kindliche Mutation und den aussagekräftigen SNP umspannt. Die Sequenzierung der Colony-PCR zeigte die in Tabelle 3.8 beschriebene Verteilung, welche eine Zuordnung der Mutation zum paternalen Allel zulässt.

\begin{tabular}{|l|l|}
\hline 4 Klone Mutation & 10x AGAT-Wiederholungen \\
\hline 6 Klone Wildtyp & $9 x$ AGAT-Wiederholungen \\
\hline
\end{tabular}

Tab. 3.8: Ergebnis der Sequenzierung der Colony-PCR-Produkte des Patienten 5. 


\section{Familie 6: Patient 2291-1}

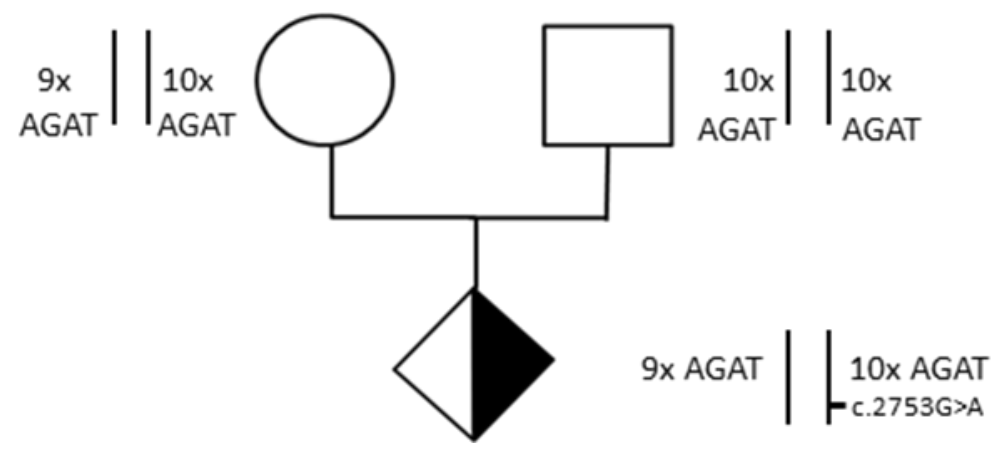

Abb. 3.15: Stammbaum Familie 6: Die Mutter und das betroffene Kind sind in dem SNP rs 59147613 heterozygot 9x AGAT/ 10x AGAT, der Vater ist homozygot für 10x AGAT. Die Mutation im Exon 10, c.2753G>A liegt auf dem Allel mit den 10x AGAT-Wiederholungen. [9x bzw.10x AGAT]: $9 x$ bzw. 10x AGAT-Wiederholungen.

Dieser Patient weist in Exon 10 an der Stelle c.2753 einen Basenaustausch von Guanin nach Adenin auf (c.2753G>A, p.W918X). In der Familie 6 erwies sich derselbe SNP wie bei Familie 5 als aussagekräftig, und es wurde nach derselben Methode vorgegangen. Das Ergebnis der Sequenzierung von 12 Colony-PCR-Produkten zeigt Tabelle 3.9.

\begin{tabular}{|l|l|}
\hline 4 Klone Mutation & 10x AGAT-Wiederholungen \\
\hline 6 Klone Wildtyp & 9x AGAT-Wiederholungen \\
\hline 2 Mischklone & \\
\hline
\end{tabular}

Tab. 3.9: Ergebnis der Sequenzierung der Colony-PCR-Produkte des Patienten 6.

Somit ist in dieser Familie das paternale Allel von der Mutation betroffen. 


\section{Familie 7: Patient 3351-1}
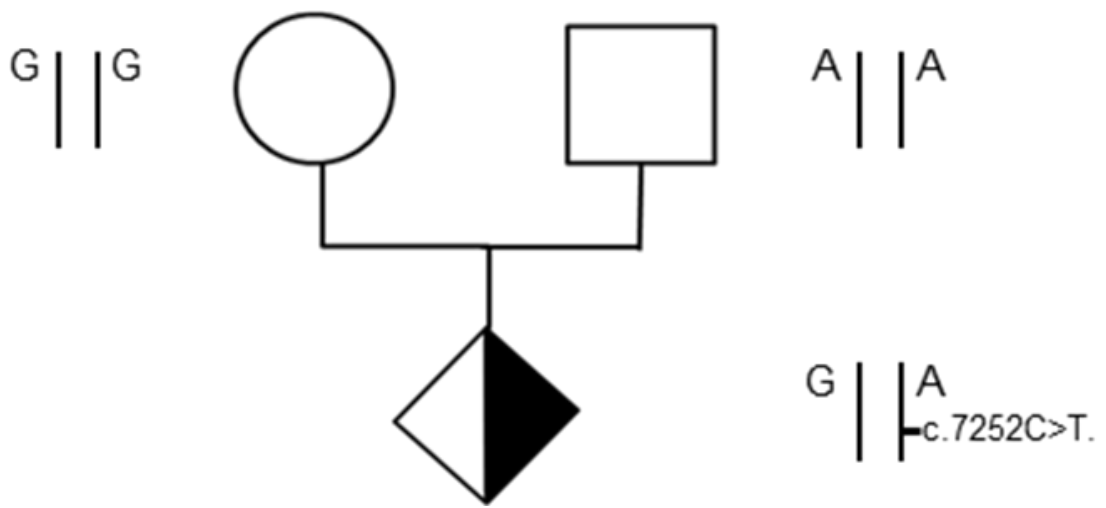

Abb. 3.16: Stammbaum Familie 7: Im aussagekräftigen SNP rs 13253647 ist die Mutter homozygot GG, der Vater AA, das Kind heterozygot GA. Die kindliche Mutation in Exon 34, c.7252C>T liegt auf dem A-Allel.

Der Patient hat einen heterozygoten Basenaustausch im Exon 34 an der Stelle c.7252 von Cytosin zu Thymin (c.7252C>T, p.R2418X). Dies führt zu einem vorzeitigen Stopcodon. Mit den Primern SNP CHD7 I34F/R und SNP CHD7 I32-I33F/R wurden mithilfe der Immolase verschiedene PCR-Produkte (779 Bp und $1287 \mathrm{Bp}$ lang) des Kindes und der Eltern hergestellt und sequenziert. Im SNP rs 13253647 ist das Kind heterozygot AG, die Mutter GG und der Vater AA. Mit der HotStar HiFidelity-DNA-Polymerase und mit dem Primerpaar SNP CHD7 I32-I33F und CHD7 Diag 34.1R wurde ein PCR-Produkt mit einer Produktlänge von $1643 \mathrm{Bp}$ hergestellt. Nach der Gelextraktion der gewünschten Bande (s. 2.2.12) und anschließender Klonierung, Colony-PCR und Sequenzierung zeigte sich das in Tabelle 3.10 dargelegte Ergebnis.

\begin{tabular}{|l|l|}
\hline 2 Klone Mutation & A im SNP \\
\hline 5 Klone Wildtyp & G im SNP \\
\hline 1 Klon Mutation & G im SNP \\
\hline
\end{tabular}

Tab. 3.10: Ergebnis der Sequenzierung der Colony-PCR-Produkte des Patienten 7.

An dieser Stelle ließ sich nur die Vermutung aufstellen, dass das paternale Allel betroffen ist. So wurde nach diesem Ergebnis das Experiment mit einer anderen ProofreadingPolymerase wiederholt. Nach der Etablierung der peqGOLD Pwo-DNA-Polymerase (s. 2.2.7.3) ergab sich das in Tabelle 3.11 dargestellte Ergebnis. 


\begin{tabular}{|l|l|}
\hline 5 Klone Mutation & A im SNP \\
\hline 7 Klone Wildtyp & G im SNP \\
\hline 5 Mischklone & \\
\hline
\end{tabular}

Tab. 3.11: Ergebnis der Sequenzierung der Colony-PCR-Produkte des Patienten 7. Das AusgangsPCR-Produkt wurde mit der peqGOLD Pwo-DNA-Polymerase erzeugt.

So konnte hier festgestellt werden, dass die Mutation auf dem väterlichen Allel liegt. 


\section{Familie 8: Patient 3260-1}

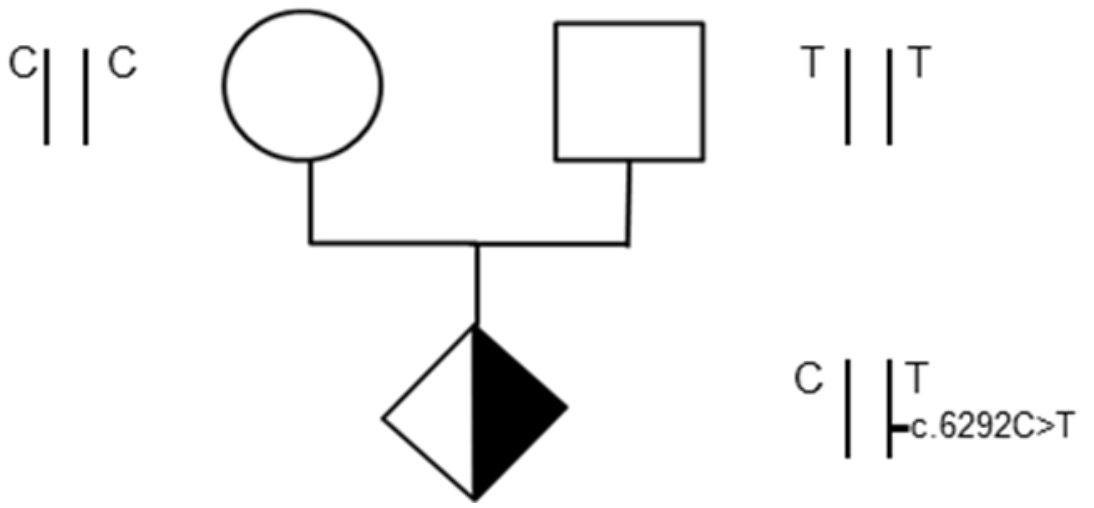

Abb. 3.17: Stammbaum Familie 8: Die Mutter ist im informativen SNP rs 3829054 homozygot CC, der Vater homozygot TT, das betroffene Kind heterozygot CT. Die Mutation in Exon 31, c.6292C>T liegt auf dem T-Allel.

Bei diesem Patienten liegt heterozygot eine Mutation in Exon 31 an der Position c.6292 von Cytosin nach Thymin (c.6292C>T, p.R2098X) vor, welche zu einem vorzeitigen Stopcodon führt. Es wurde von den elterlichen und der kindlichen DNA ein $1594 \mathrm{Bp}$ langes PCR-Produkt mit der HotStar HiFidelity-Polymerase unter Verwendung der Primer CHD7 Diag 31.1F und SNP CHD7 I31R erzeugt und sequenziert. Als weiterer Sequenzprimer diente der Primer SNP CHD7 E31I31R. Die SNPs rs 3829054 und rs 3814483 zeigten sich als informativ. Für die Haplotypbestimmung wurde der Erstgenannte verwendet. Aufgrund der zunächst nicht eindeutigen Zuordnungsmöglichkeiten zum paternalen oder maternalen Allel in anderen Familientriplets wurde bei diesem Patienten zunächst eine andere Methode versucht. Es wurden von den Kolonien Plasmide hergestellt und diese sequenziert (s. 2.2.16). Dabei zeigte aber nur 1 Plasmid die Mutation und ein $\mathrm{T}$ im SNP, weitere 9 Plasmide zeigten Sequenzen für Fremdproteine. Deshalb wurde ein neues PCR-Produkt mit der DNAPolymerase HotStar HiFidelity und auch mit der Phusion High-Fidelity hergestellt, aber vor der weiteren Benutzung aus dem Gel extrahiert (s. 2.2.12). Die Tabelle 3.12 zeigt das Ergebnis der Sequenzen der Colony-PCR.

\begin{tabular}{|l|l|}
\hline 10 Klone Mutation & T im SNP \\
\hline 1 Klon Wildtyp & G im SNP \\
\hline 1 Mischklon & \\
\hline
\end{tabular}

Tab. 3.12: Ergebnis der Sequenzierung der Colony-PCR-Produkte des Patienten 8.

In dieser Familie liegt die Mutation folglich auf dem paternalen Allel. 


\section{Familie 9: Patient 2249-1}
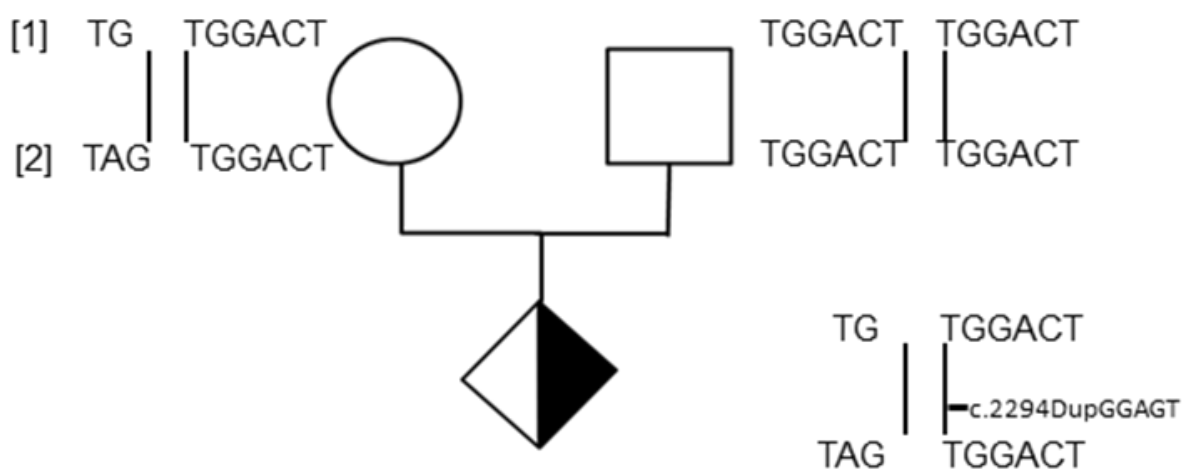

Abb. 3.18: Stammbaum Familie 9: In den aussagekräftigen SNPs rs 35504039 [1] und rs 5891777 [2] sind die Mutter und das Kind jeweils heterozygot TG/TGGACT und TAG/TGGACT, der Vater in beiden homozyogt TGGACT. Die Mutation in Exon 5, c.2294dupGGAGT, liegt auf dem TGGACT-Allel.

Der Patient weist eine Mutation c.2294dupGGAGT in Exon 5 auf. Für die Haplotypanalyse wurde zunächst ein PCR-Produkt (1306 Bp) mit den Primern CHD7 Diag5F und Diag6R hergestellt. Erst mit einem weiteren Primerpaar SNP CHD7 In4NeuF/R konnten zwei aufeinanderfolgende aussagekräftige SNPs detektiert werden, rs 35504039 und rs 5891777. Das Kind ist heterozygot TG/TGGACT im ersten und TAG/TGGACT im zweiten SNP, der Vater homozygot TGGACT an den genannten Stellen. Da die maternale Sequenz schlecht lesbar war, wurde sowohl die mütterliche DNA als auch die kindliche DNA mithilfe der peqGOLD Pwo-DNA-Polymerase und mit den Primern CHD7 Diag5F und SNP CHD7 In4NeuR (Produktlänge $446 \mathrm{Bp}$ ) amplifiziert und kloniert. Die Sequenzen der Klone der mütterlichen DNA zeigten folgende Verteilung: 9 Klone wiesen in ihrer Sequenz 2x TGGACT auf, 5 Klone 1x TG und 1x TAG und einen Mischklon. Somit ist die Mutter in beiden SNPs wie das Kind heterozygot. Das Kind muss das TG bzw. TAG-Allel von der Mutter geerbt haben und das TGGACT-Allel vom Vater. In Tabelle 3.13 ist die Verteilung der Klone der kindlichen DNA dargestellt. Sie zeigt eine Zuordnung der Mutation zu dem paternalen Allel.

\begin{tabular}{|l|l|}
\hline 5 Klon Mutation & 2x TGGACT \\
\hline 5 Klone Wildtyp & $1 \times$ TG $+1 \times$ TAG \\
\hline 2 Mischklon & \\
\hline
\end{tabular}

Tab. 3.13: Ergebnis der Sequenzierung der Colony-PCR-Produkte des Patienten 9. 


\section{Familie 10: Patient 3696-1}
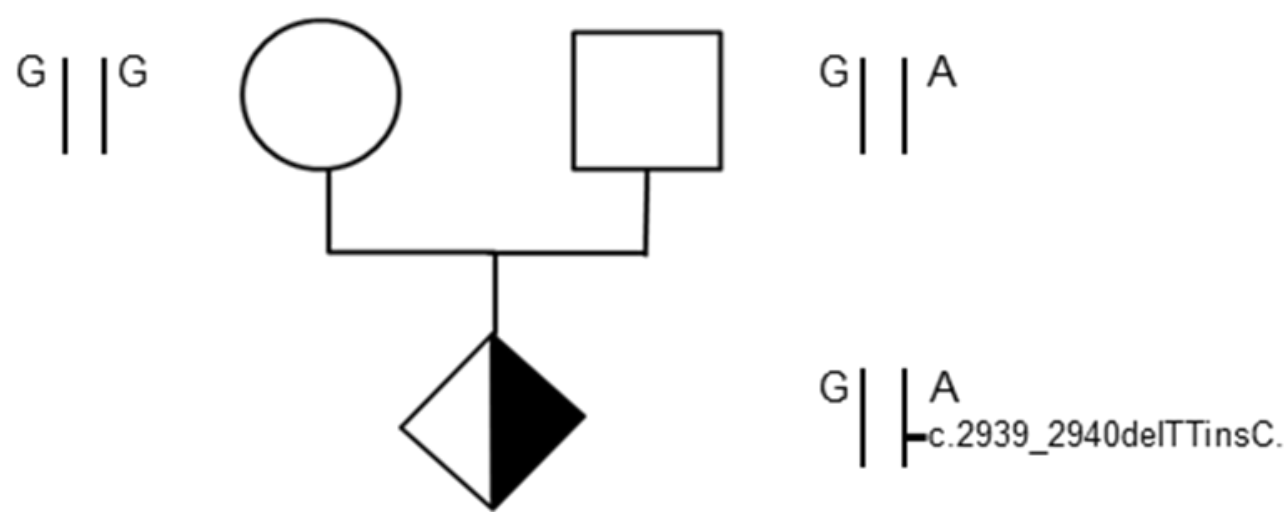

Abb. 3.19: Stammbaum Familie 10: Im informativen SNP rs 4509369 sind der Vater und das Kind heterozygot GA, die Mutter homozygot GG. Die Mutation c.2939_2940delTTinsC in Exon 11 liegt auf dem A-Allel.

Die Mutation im Exon 11, c.2939_2940delTTinsC, ist aus der molekulargenetischen Untersuchung bekannt. Diese Deletion von TT und die Insertion von C führen zu einer Verschiebung des Leserahmens (Frameshift). Es wurde ein PCR-Produkt mit der peqGOLD Pwo-DNA-Polymerase mit den Primern CHD7 Diag 10F und SNP CHD7 12.3R sowie ein 2. mit dem Primerpaar SNP CHD7 19-11F/R hergestellt. Es wurde ein aussagekräftiger SNP rs 4509369 in den Sequenzen detektiert: Der Vater und das Kind sind heterozygot GA, die Mutter homozygot GG. D. h. dass das A-Allel vom Vater und das G-Allel von der Mutter stammen muss. Das PCR-Produkt mit dem Primerpaar SNP CHD7 19-11F/R konnte nach einem A-tailing (s. 2.2.8) für die Klonierung genutzt werden. Die Sequenzen der KlonierungsPCR zeigten eine Zuordnung der Mutation zum paternalen Allel, wie der Tabelle $3.14 \mathrm{zu}$ entnehmen ist.

\begin{tabular}{|l|l|}
\hline 7 Klone Wildtyp & G im SNP \\
\hline 4 Klone Mutation & A im SNP \\
\hline
\end{tabular}

Tab. 3.14: Ergebnis der Sequenzierung der Colony-PCR-Produkte des Patienten 10. 


\subsubsection{Familien mit nicht eindeutiger Zuordnung}

\section{Familie 11: Patient 1466-1}

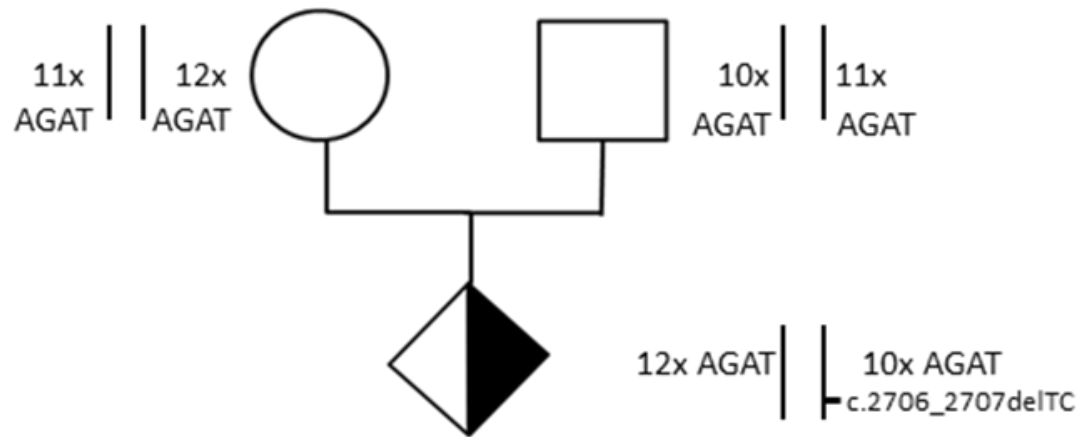

Abb. 3.20: Stammbaum Familie 11: Im informativen SNP rs 59147613 ist die Mutter heterozygot 11x AGAT/ 12x AGAT, der Vater 10x AGAT/ 11x AGAT und das Kind 10x AGAT/ 12x AGAT. In dieser Familie konnte keine eindeutige Zuordnung zum paternalen oder maternalen Allel gemacht werden. Lediglich aufgrund der höheren Anzahl an Klonen mit der Mutation auf dem Allel mit den 10x ATAGWiederholungen kann eine paternale Zuordnung angenommen werden. [10x, 11x bzw. 12x AGAT]: 10 $x, 11 x$ bzw. 12x AGAT-Wiederholungen.

Die Deletion TC an Position c.2706-2707 in Exon 10 führt zu einer Verschiebung des Leserahmens (Frameshift). Wie bei den Patienten 5 und 6 wurden PCR-Produkte mit den Primern SNP CHD7 19-I11F/R und SNP CHD7 I12F/R hergestellt und sequenziert. Von den in der Literatur bekannten Polymorphismen konnte der SNP rs 59147613 als aussagekräftig verifiziert werden. Die Mutter ist heterozygot 11x AGAT/ 12x AGAT, der Vater 10x AGAT/ 11x AGAT und das Kind 10x AGAT/ 12x AGAT. Mit der peqGOLD Pwo-DNA-Polymerase wurde mithilfe der Primer CHD7 Diag 10F und SNP CHD7 I12.3R ein Produkt von 1853 Bp hergestellt und kloniert, amplifiziert und sequenziert. Anhand des Ergebnisses konnte jedoch keine eindeutige Zuordnung zu einem Allel gemacht werden. So wurde abermals ein neues PCR-Produkt hergestellt und zum Ausschluss einer möglich aufgetretenen Rekombination während der Amplifizierung sequenziert. Die Tabelle 3.15 zeigt die Verteilung im 1. Durchlauf. 


\begin{tabular}{|l|l|}
\hline 5 Klone Wildtyp & 12x AGAT-Wiederholungen \\
\hline 1 Klon Wildtyp & $10 x$ AGAT-Wiederholungen \\
\hline 6 Klone Mutation & $10 x$ AGAT-Wiederholungen \\
\hline 2 Klone Mutation & $12 x$ AGAT-Wiederholungen \\
\hline 1 Mischklon & \\
\hline
\end{tabular}

Tab. 3.15: Ergebnis der Sequenzierung der Colony-PCR-Produkte des Patienten 11.

Die Kolonien des neuen PCR-Produktes wiesen die in Tabelle 3.16 dargelegte Verteilung auf.

\begin{tabular}{|l|l|}
\hline 3 Klone Wildtyp & 12x AGAT-Wiederholungen \\
\hline 1 Klone Wildtyp & $9 x$ AGAT-Wiederholungen \\
\hline 1 Klon Wildtyp & $10 x$ AGAT-Wiederholungen \\
\hline 1 Klon Wildtyp & $11 \times$ AGAT-Wiederholungen \\
\hline 2 Klone Mutation & $10 x$ AGAT-Wiederholungen \\
\hline 2 Klone Mutation & \\
\hline
\end{tabular}

Tab. 3.16: Ergebnis der Sequenzierung der Colony-PCR-Produkte des neuen PCR-Produktes des Patienten 11.

Es zeigte sich, dass letztendlich keine eindeutige Zuordnung möglich ist, da auch die Ergebnisse des 2. Durchlaufs keine einheitliche Kombination aufweisen. Außerdem gab es in diesem 2. Durchlauf auch Kolonien, die in ihrer Sequenz nur 9x AGAT aufwiesen. Wahrscheinlich liegt hier ein Amplifikationsfehler der Polymerase vor. Lediglich aufgrund der höheren Anzahl an Kolonien, in denen die Mutation in dem 10x AGAT-Allel liegt, kann vermutet werden, dass auch in dieser Familie das paternale Allel von der Mutation betroffen ist. 


\section{Familie 12: Patient 1870}

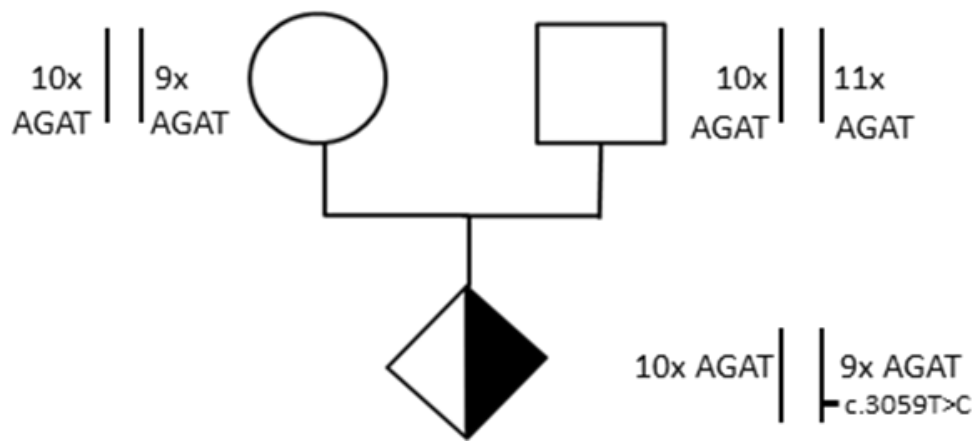

Abb. 3.21: Stammbaum Familie 12: Der SNP rs 59147613 ist aussagekräftig: Die Mutter und das Kind sind heterozygot 9x AGAT/ 10x AGAT, der Vater 10x AGAT/ 11x AGAT. Die Mutation c.3059T>C in Exon 12 liegt wahrscheinlich auf dem maternalen Allel.

Bei diesem Patienten ist in Exon 12 die Mutation c.3059T>C aus der vorangegangenen Diagnostik bekannt. Sie führt zu einem Aminosäurenaustausch von Leucin zu Serin (p.L1020S). Für diese Familie wurden die gleichen Primer zur PCR-Produktherstellung verwendet wie in Familie 5, 6 und 11. Auch hier konnte der SNP rs 59147613 für aussagekräftig bewertet werden. Die Mutter und das Kind sind heterozygot 9x AGAT/ 10x AGAT und der Vater 10x AGAT/ 11x AGAT. So muss das Kind das 9x AGAT-Allel von der Mutter und das 10x AGATAllel vom Vater geerbt haben. Das PCR-Produkt (1853 Bp), das die Mutation und den SNP enthält, wurde mit der peqGOLD Pwo-DNA-Polymerase hergestellt. Die Ergebnisse der Sequenzierung der Colony-PCR-Produkte mit der Immolase-Polymerase zeigt die Tabelle 3.17 .

\begin{tabular}{|l|l|}
\hline 3 Klone Wildtyp & 10x AGAT-Wiederholungen \\
\hline 2 Klone Mutation & 10x AGAT-Wiederholungen \\
\hline 5 Klone Mutation & $9 x$ AGAT-Wiederholungen \\
\hline
\end{tabular}

Tab. 3.17: Ergebnis der Sequenzierung der Colony-PCR-Produkte des Patienten 12.

Im Anschluss wurden weitere Colony-PCR-Produkte mit der peqGOLD Pwo-DNAPolymerase hergestellt, um die Ergebnisse zu verifizieren. Das Ergebnis zeigt die Tabelle 3.18 . 


\begin{tabular}{|l|l|}
\hline 6 Klone Wildtyp & 10x AGAT-Wiederholungen \\
\hline 2 Klone Wildtyp & $9 x$ AGAT-Wiederholungen \\
\hline 4 Klone Mutation & $9 x$ AGAT-Wiederholungen \\
\hline
\end{tabular}

Tab. 3.18: Ergebnis der Sequenzierung der Colony-PCR-Produkte mit der peqGOLD Pwo-DNAPolymerase des Patienten 12.

In dieser Familie war keine eindeutige Zuordnung zu einem Allel möglich. Vermutlich betrifft aufgrund der höheren Anzahl an Kolonien, in denen die Mutation auf dem 9x AGAT-Allel liegt, die Mutation in dieser Familie das maternale Allel. 


\section{Familie 13: Patient 27470}

Bei diesem Patienten wurde eine Splice-site-Mutation im Intron 23 an der Position c.5210+3A>G im Rahmen der Diagnostik entdeckt. Da es sich bei dieser Mutation um eine noch nicht in der Literatur beschriebene handelt, wurde die Mutation weiter abgeklärt. Dafür wurde RNA aus kindlichem EDTA-Blut isoliert und cDNA hergestellt (s. 2.2.3, 2.2.9). Anschließend wurde eine PCR mit den Primerpaaren CHD7 RT Ex22-24F/R an der Patienten- cDNA und einer Kontroll-cDNA mithilfe der Immolase-Polymerase durchgeführt (s. 2.2.6).

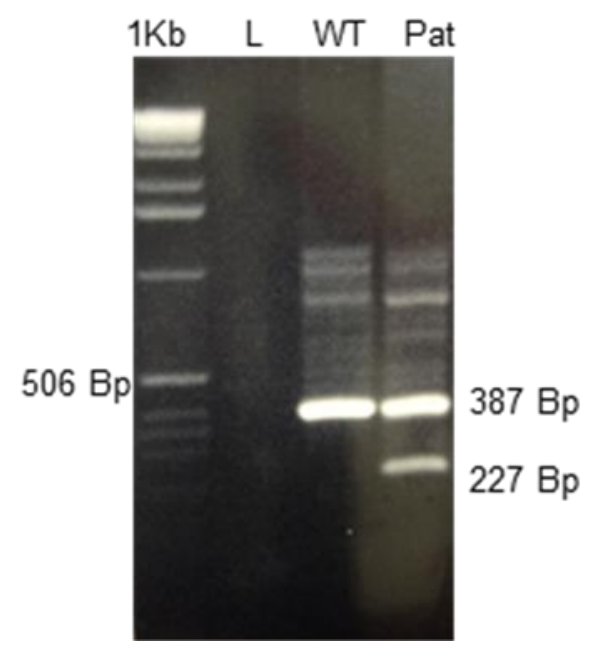

Abb. 3.22: PCR-Produkte einer RT-PCR auf einem Agarosegel $1 \%$ : [L] Negativkontrolle, [WT] Wildtyp, [Pat] Patient: Neben der Wildtyp-Bande mit einer Länge von $387 \mathrm{Bp}$ zeigte sich ein 2. kürzeres PCR-Produkt (227 Bp).

Bei dem Patienten zeigten sich zwei Banden (387 Bp und $227 \mathrm{Bp}$ ), während die WildtypKontrolle lediglich eine Bande in der erwarteten Größe von $387 \mathrm{Bp}$ aufweist (s. Abbildung 3.22). Die zwei Banden des PCR-Produktes der Patienten-cDNA wurden extrahiert und sequenziert (s. 2.2.12, 2.2.17, 2.2.18). Das kürzere PCR-Produkt musste zunächst hochamplifiziert werden.

Die Sequenzanalyse des kürzeren Produktes zeigt Teilbereiche des Exons 22, an die sich direkt die Sequenz von Exon 24 anschließt. Dieses Ergebnis bestätigt die Vermutung, dass es sich bei der Mutation c.5210+3A>G um eine Splice-site-Mutation handelt. Durch den Wegfall dieser Splice-site kommt es zu einem Verlust von Exon 23 des Transkriptes. 


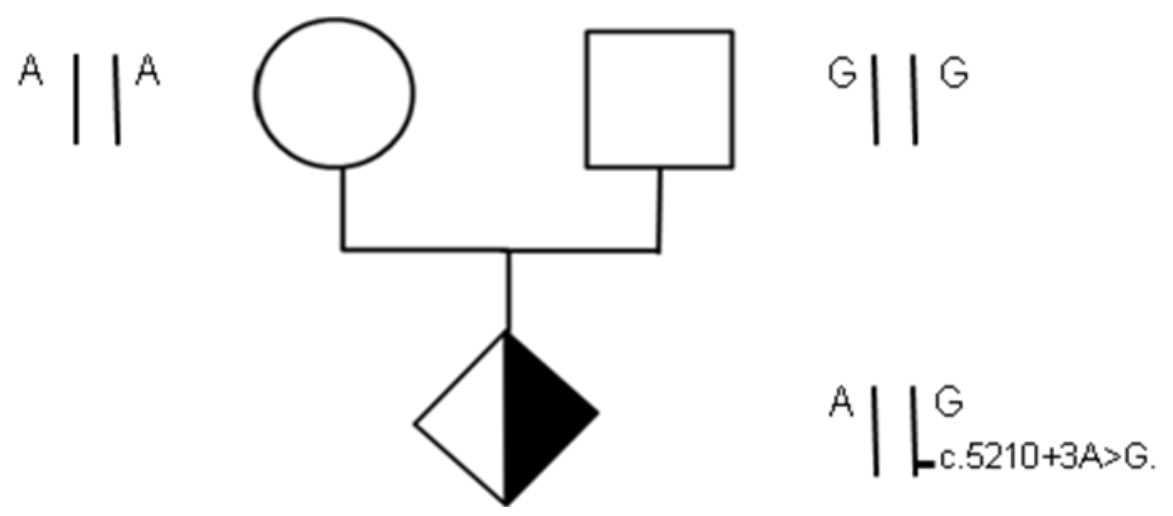

Abb. 3.23: Stammbaum Familie 13: Im aussagekräftigen SNP rs 4526395 ist die Mutter homozygot AA, der Vater GG und das Kind AG. Die Mutation liegt wahrscheinlich auf dem G-Allel.

Nach der Mutationsanalyse wurde mithilfe der Primer SNP CHD7 In21F/R der Intronbereich 21 auf informative SNP untersucht (Produktgröße $1381 \mathrm{Bp}$ ). Dabei wurde der SNP rs 4526395 als aussagekräftig gefunden. Für die Klonierung wurde mithilfe der HotStar HiFidelity-DNA-Polymerase ein 2074 Bp großes PCR-Produkt, eingegrenzt von den Primern SNP CHD7 In21F und CHD7 Diag23R, hergestellt. Die Bande im Agarosegel wurde extrahiert und anschließend kloniert. Die Tabelle 3.19 zeigt die Verteilung der Klone.

\begin{tabular}{|l|l|}
\hline 4 Klone Mutation & A im SNP \\
\hline 14 Klone Wildtyp & A im SNP \\
\hline
\end{tabular}

Tab. 3.19: Ergebnis der Sequenzierung der Colony-PCR des Patienten 13.

Daraufhin erfolgte eine erneute PCR-Produktherstellung, dieses Mal jedoch mit der peqGOLD Pwo-DNA-Polymerase. Nach Gelextraktion, Klonierung und Colony-PCR ergab sich das in Tabelle 3.20 genannte Ergebnis.

\begin{tabular}{|l|l|}
\hline 12 Klone Mutation & G im SNP \\
\hline 2 Klone Mutation & A im SNP \\
\hline 9 Klone Wildtyp & A im SNP \\
\hline 1 Mischklon & \\
\hline
\end{tabular}

Patienten 13. 
Trotz der nicht eindeutigen Ergebnisse lässt sich die Vermutung aufstellen, dass die Mutation auf dem paternalen Allel liegt: Von insgesamt 42 Klonen zeigen 12, dass das väterliche Allel betroffen ist im Verhältnis zu 6 Klonen, die die Möglichkeit darstellen, dass die Mutation auf dem mütterlichen Allel liegt. 


\subsubsection{Familien mit nicht aussagekräftigem Polymorphismus}

Bei 17 weiteren Familien konnte kein informativer SNP gefunden werden, der für die Haplotypbestimmung genutzt werden konnte. Die jeweils bei den Familien untersuchten Polymorphismen sind der Tabelle 3.21 zu entnehmen.

\begin{tabular}{|c|c|c|c|c|}
\hline Familie & Mutation & verwendete Primer & $\begin{array}{l}\text { Produktgröße } \\
\text { (Bp) }\end{array}$ & $\begin{array}{l}\text { Bekannte SNP } \\
\text { Nicht informativ }\end{array}$ \\
\hline 14 & $\begin{array}{l}\text { Ex31 } \\
\text { c.6271T>C } \\
\text { W2091R }\end{array}$ & $\begin{array}{l}\text {-SNP CHD7 E31- } \\
\text { I31F/R }\end{array}$ & 842 & $\begin{array}{l}\text { rs41265252, rs3763592, } \\
\text { rs41312170, rs6999971, } \\
\text { rs2068096, rs41312172, } \\
\text { rs61753399, rs34527521, } \\
\text { rs61729627, rs3814483, } \\
\text { rs3829054 }\end{array}$ \\
\hline 15 & $\begin{array}{l}\text { Ex. } 11 \\
\text { c. } 2830 \mathrm{C}>\mathrm{T} \\
\text { p.R947X }\end{array}$ & $\begin{array}{l}\text {-SNP CHD7 Ex9F/R } \\
\text {-SNP CHD7 I9-11F/R } \\
\text {-SNP CHD7 I12F/R } \\
\text {-CHD7 Diag Ex9IntF }\end{array}$ & $\begin{array}{l}1487 \\
1154 \\
741 \\
\text { Seq } \\
\text { Seq }\end{array}$ & $\begin{array}{l}\text { rs11782077, rs6471902, } \\
\text { rs10098584, rs13271006, } \\
\text { rs6997401, rs4509369, } \\
\text { rs6986860, rs28539174, } \\
\text { rs35924045, rs71559309, } \\
\text { rs34157849, rs72348418, } \\
\text { rs72029230, rs34150494, } \\
\text { rs71750503, rs5891779, } \\
\text { rs59147613 }\end{array}$ \\
\hline 16 & $\begin{array}{l}\text { Ex.22 } \\
\text { c. } 4858 C>G \\
\text { p.R1620G }\end{array}$ & $\begin{array}{l}\text {-SNP CHD7 E22- } \\
\text { I23F/R } \\
\text {-SNP CHD7 } \\
\text { Ex22F2/R2 }\end{array}$ & $\begin{array}{l}1319 \\
708\end{array}$ & $\begin{array}{l}\text { rs41265248, rs71640288, } \\
\text { rs10957162, rs73254563, } \\
\text { rs61737194 }\end{array}$ \\
\hline 17 & $\begin{array}{l}\text { Ex.9 } \\
\text { c. } 2643 T>A \\
\text { p.Y881x }\end{array}$ & $\begin{array}{l}\text {-SNP CHD7 Ex9F/R } \\
\text {-SNP CHD7 I12F/R } \\
\text {-CHD7 Diag Ex9F/R } \\
\text {-CHD7 Diag Ex9 IntF }\end{array}$ & $\begin{array}{l}1487 \\
741 \\
\text { Seq } \\
\text { Seq }\end{array}$ & $\begin{array}{l}\text { rs11782077, rs6471902, } \\
\text { rs10098584, rs13271006, } \\
\text { rs6997401, rs35924045, } \\
\text { rs71559309, rs34157849, } \\
\text { rs72348418, rs72029230, } \\
\text { rs34150494, rs71750503, } \\
\text { rs5891779, rs59147613 }\end{array}$ \\
\hline 18 & $\begin{array}{l}\text { Ex.10 } \\
\text { c.2755delG } \\
\text { p.Glu919fs }\end{array}$ & $\begin{array}{l}\text {-SNP CHD7 Ex9F/R } \\
\text {-SNP CHD7 19-11F/R } \\
\text {-SNP CHD7 I12F/R } \\
\text {-CHD7 Diag Ex10R }\end{array}$ & $\begin{array}{l}1487 \\
1154 \\
741 \\
\text { Seq }\end{array}$ & $\begin{array}{l}\text { rs11782077, rs6471902, } \\
\text { rs10098584, rs13271006, } \\
\text { rs6997401, rs4509369, } \\
\text { rs6986860, rs28539174, } \\
\text { rs35924045, rs71559309, } \\
\text { rs34157849, rs72348418, } \\
\text { rs72029230, rs34150494, }\end{array}$ \\
\hline
\end{tabular}




\begin{tabular}{|c|c|c|c|c|}
\hline Familie & Mutation & verwendete Primer & $\begin{array}{l}\text { Produktgröße } \\
\text { (Bp) }\end{array}$ & $\begin{array}{l}\text { Bekannte SNP } \\
\text { Nicht informativ }\end{array}$ \\
\hline & & & & $\begin{array}{l}\text { rs71750503, rs5891779, } \\
\text { rs59147613 }\end{array}$ \\
\hline 19 & $\begin{array}{l}\text { Ex.32 } \\
\text { c. } 6936+1 G>T\end{array}$ & $\begin{array}{l}\text {-SNP CHD7 I31F/R } \\
\text {-CHD7 Diag Ex32F } \\
\text {-SNP CHD7 Ex32R }\end{array}$ & $\begin{array}{l}765 \\
1118\end{array}$ & $\begin{array}{l}\text { rs59181511, rs3814483, } \\
\text { rs3829054, rs10090769, } \\
\text { rs61743849, rs61733338, } \\
\text { rs7839701, rs13253647 }\end{array}$ \\
\hline 20 & $\begin{array}{l}\text { Ex33 } \\
\text { c.6983dupT }\end{array}$ & $\begin{array}{l}\text {-SNP CHD7 I34F/R } \\
\text {-CHD7 Diag } \\
\text { Ex34.1F/R }\end{array}$ & $\begin{array}{l}779 \\
395\end{array}$ & $\begin{array}{l}\text { rs3793443, rs3793444, } \\
\text { rs17826359, rs61742801, } \\
\text { rs61746518, rs61742801, } \\
\text { rs2272727, rs41315633, } \\
\text { rs36091844 }\end{array}$ \\
\hline 21 & $\begin{array}{l}\text { Ex.32 } \\
\text { c.6850C>T }\end{array}$ & $\begin{array}{l}\text {-SNP CHD7 I31F/R } \\
\text {-CHD7 Diag Ex32F } \\
\text {-SNP CHD7 Ex32R }\end{array}$ & $\begin{array}{l}765 \\
1118\end{array}$ & $\begin{array}{l}\text { rs61743849, rs61733338, } \\
\text { rs7839701, rs13253647, } \\
\text { rs59181511, rs3814483, } \\
\text { rs3829054, rs10090769 }\end{array}$ \\
\hline 22 & $\begin{array}{l}\text { Ex.2 } \\
\text { c.601C>T }\end{array}$ & $\begin{array}{l}\text { CHD7 Diag 2.1F } \\
\text { SNP CHD7E2-I2R } \\
\text { SNP CHD7 In1.1F } \\
\text { CHD7 Diag 2.2R }\end{array}$ & $\begin{array}{l}1926 \\
1649 \\
\text { Seq }\end{array}$ & $\begin{array}{l}\text { rs61742851, rs61995713, } \\
\text { rs13248404, rs13284829, } \\
\text { rs41305525, rs71640285, } \\
\text { rs71640286, rs45536935, } \\
\text { rs7836586, rs16926450, } \\
\text { rs17825594, rs16926453, } \\
\text { rs41272435, rs61742851 }\end{array}$ \\
\hline 23 & $\begin{array}{l}\text { Ex18 } \\
\text { c.4282delG }\end{array}$ & $\begin{array}{l}\text { SNP CHD7 I16-18F } \\
\text { SNP CHD7 Ex17R } \\
\text { CHD7 Diag Ex18F/R }\end{array}$ & $\begin{array}{l}636 \\
379\end{array}$ & $\begin{array}{l}\text { rs7005873, rs34488222, } \\
\text { rs41304212, rs41265244, } \\
\text { rs41265246, rs7844902 }\end{array}$ \\
\hline 24 & $\begin{array}{l}\text { Ex15 } \\
\text { c.3375_3376 } \\
\text { delAA }\end{array}$ & $\begin{array}{l}\text { SNP CHD7 In 14F/R } \\
\text { SNP CHD7 EX15F/R }\end{array}$ & $\begin{array}{l}1224 \\
1058\end{array}$ & $\begin{array}{l}\text { rs6996597, rs6996775, } \\
\text { rs62526526, rs } 7016832, \\
\text { rs28667506, rs6997208, } \\
\text { rs6997222, rs41272442, } \\
\text { rs41306148, rs } 4507803\end{array}$ \\
\hline 25 & $\begin{array}{l}\text { Ex2 } \\
\text { c.1840C>T }\end{array}$ & $\begin{array}{l}\text { SNP CHD7 E2-I2F/R } \\
\text { CHD7 Diag Ex2.2R } \\
\text { CHD7 Diag Ex2.3R } \\
\text { CHD7 Diag Ex2.4R } \\
\text { CHD7 Diag Ex2.5F/R } \\
\text { SNP CHD7 In2Anf.F/R }\end{array}$ & $\begin{array}{l}1475 \\
\text { Seq } \\
\text { Seq } \\
\text { Seq } \\
\text { Seq } \\
1629\end{array}$ & $\begin{array}{l}\text { rs61742851, rs61995713, } \\
\text { rs13248404, rs13284829, } \\
\text { rs41305525, rs71640285, } \\
\text { rs71640286, rs45536935, } \\
\text { rs7836586, rs41304214, } \\
\text { rs7011801, rs12542177 }\end{array}$ \\
\hline 26 & $\begin{array}{l}\text { Ex2 } \\
c .1565 G>T\end{array}$ & $\begin{array}{l}\text { SNP CHD7 E2-I2F/R } \\
\text { CHD7 Diag Ex2.5F/R }\end{array}$ & $\begin{array}{l}1475 \\
\text { Seq }\end{array}$ & $\begin{array}{l}\text { rs61742851, rs61995713, } \\
\text { rs13248404, rs13284829, }\end{array}$ \\
\hline
\end{tabular}




\begin{tabular}{|c|c|c|c|c|}
\hline Familie & Mutation & verwendete Primer & $\begin{array}{l}\text { Produktgröße } \\
\text { (Bp) }\end{array}$ & $\begin{array}{l}\text { Bekannte SNP } \\
\text { Nicht informativ }\end{array}$ \\
\hline & p.G522V & SNP CHD7 In2Anf.F/R & 1629 & $\begin{array}{l}\text { rs41305525, rs71640285, } \\
\text { rs71640286, rs45536935, } \\
\text { rs7836586, rs41304214, } \\
\text { rs7011801, rs12542177 }\end{array}$ \\
\hline 27 & $\begin{array}{l}\text { Ex3 } \\
\text { c. } 1735 \mathrm{C}>\mathrm{T}, \\
\text { p.Q579X }\end{array}$ & $\begin{array}{l}\text { SNP CHD7 } \\
\text { IN2E3NeuF } \\
\text { CHD7 Diag Ex3.1R } \\
\text { CHD7 Diag 3.2F } \\
\text { SNP CHD7 In3NeuR }\end{array}$ & $\begin{array}{r}1160 \\
1066\end{array}$ & $\begin{array}{l}\text { rs7009754, rs6471900, } \\
\text { rs6471901, rs11277828, } \\
\text { rs45505899, rs62526494, } \\
\text { rs34979623 }\end{array}$ \\
\hline 28 & $\begin{array}{l}\text { Ex2 } \\
\text { c.934C>T, } \\
\text { p.R312X }\end{array}$ & $\begin{array}{l}\text { SNP CHD7 In1.1F } \\
\text { CHD7 Diag 2.2R } \\
\text { CHD7 Diag2.3R } \\
\text { SNP CHD7E2-I2F/R }\end{array}$ & $\begin{array}{r}1649 \\
1475\end{array}$ & $\begin{array}{l}\text { rs16926450, rs17825594, } \\
\text { rs16926453, rs41272435, } \\
\text { rs61742851, rs61995713, } \\
\text { rs13248404, rs13284829, } \\
\text { rs41305525, rs71640285, } \\
\text { rs71640286, rs45536935, } \\
\text { rs7836586 }\end{array}$ \\
\hline 29 & $\begin{array}{l}\text { Ex8 } \\
\text { c.2504_2508 } \\
\text { delATCTT, } \\
\text { p.Y835SfsX14 }\end{array}$ & SNP CHD7 In8F/R & 1114 & $\begin{array}{l}\text { rs35632150, rs7813054, } \\
\text { rs13438807 }\end{array}$ \\
\hline 30 & $\begin{array}{l}\text { Ex21/Int21 } \\
\text { c. } 4844 T>C, \\
4846 \_4850 \\
+3 \text { delTATGGG } \\
\text { TA }\end{array}$ & $\begin{array}{l}\text { SNP CHD7 19-21F/R } \\
\text { SNP CHD7 20-21F/R }\end{array}$ & $\begin{array}{l}1829 \\
1853\end{array}$ & $\begin{array}{l}\text { rs62526528, rs11989183, } \\
\text { rs13488512, rs71640287, } \\
\text { rs4449834, rs4307377, } \\
\text { rs4526395 }\end{array}$ \\
\hline
\end{tabular}

Sequenzierprimer, [Ex] Exon 


\section{DISKUSSION}

\subsection{CHD-Familie}

Die CHD-Gene kodieren im Allgemeinen für Proteine, die durch ATP-Hydrolyse den HistonDNA-Kontakt in Nukleosomen, einer Einheit aus 1,7 DNA-Umwindungen und acht Histonproteinen, verändern und dadurch eine Konformationsänderung des Chromatins bewirken können (Becker und Hörz 2002). Über eine Konformationsänderung des Chromatins hat die Zelle die Möglichkeit, u. a. die Expression einzelner Gene zu kontrollieren (Hall und Georgel 2007). In stark kondensiertem Chromatin (Heterochromatin) ist eine Genexpression nicht möglich, während in gering kondensiertem Chromatin (Euchromatin) eine Transkription des entsprechenden Gens stattfinden kann. Aufgrund ihrer Funktion bilden die CHD-Proteine eine Gruppe von Chromatinremodellern.

Chromatinremodeller oder Chromatin-remodelling-Komplexe können je nach Art Histonoktamere verschieben oder entfernen oder auch einzelne Histone austauschen, um den für die Transkription wichtigen Komponenten - wie der RNA-Polymerase oder bestimmten Transkriptionsfaktoren - den Kontakt zu der DNA zu ermöglichen. Den CHDProteinen ist das Vorhandensein von zwei N-terminalen $\underline{C}$ hromodomänen, einer SWI2/ SNF2

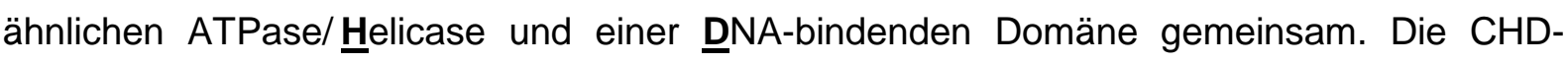
Genfamilie kann in drei Untergruppen unterteilt werden, da sich einige der CHD-Gene in ihrer Sequenz und dem Vorkommen weiterer Domänen ähneln. Beim Menschen findet man 9 verschiedene CHD-Familienmitglieder, wobei CHD1 und 2 die Subgruppe I, CHD3 und 4 die Subgruppe II und CHD5-9 die Subgruppe III bilden (Hall und Georgel 2007, Marfella und Imbalzano 2007). Mitglieder der Subgruppe III besitzen drei konservierte Regionen CR1-3, eine SANT-Domäne und zwei BRK-Domänen (Flaus et al. 2006) (vgl. Abbildung 1.1). Von anderen Chromatinremodellern ist bekannt, dass diese in großen Chromatin-remodellingKomplexen ihre Funktionen ausführen (Saha et al. 2006). So ist CHD1 in Saccharomyces

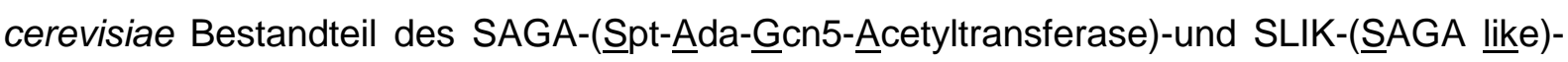
Komplexes (Pray-Grant et al. 2005), der einen Coaktivator für verschiedene Gene darstellt (Wu et al. 2004). Durch die Ergebnisse von Untersuchungen an Hefen wird angenommen, dass CHD1 die Transkription durch Bindung an Promotorregionen und die Konformationsänderung des Chromatins fördert. In Mäusestammzellen konnte gezeigt werden, dass CHD1 notwendig ist, damit die DNA als Euchromatin vorliegt, in der die DNA transkribiert werden kann (Koh et al. 2010). CHD3 und CHD4 bilden eine Kernkomponente des NuRD-(Nucleosome-remodeling-histone-Deacetylase)-Komplexes (Hall und Georgel 2007). Der NuRD-Komplex besitzt sowohl eine ATP-abhängige Chromatin-remodellingAktivität als auch eine Histon-Deacetylase-Aktivität. Der Komplex ist daran beteiligt, dass 
eine Zelle bei schwerwiegenden DNA-Schäden über einen Konzentrationsanstieg an den Proteinen p53 und p21 in die Apoptose geführt wird (Smeenk et al. 2010).

Im Rahmen des CHARGE-Syndroms ist besonders die Betrachtung des CHD7-Gens erforderlich.

\subsubsection{CHD7}

Erstmals im Jahr 2004 wurden im CHD7-Gen Mutationen beschrieben, die für die Ausbildung des CHARGE-Syndroms verantwortlich gemacht werden (Vissers et al. 2004). Für CHD7 konnte gezeigt werden, dass es in vitro sowohl an mono- als auch dimethylierte Formen des vierten Lysins im Histon 3 (H3K4) bindet als auch damit interagiert (Schnetz et al. 2009). Die Bindungsstellen für CHD7 zeigen zahlreiche Eigenschaften von Enhancer-Elementen, sodass es sich bei CHD7 vermutlich um ein an Enhancerbereiche bindendes Protein handelt (Schnetz et al. 2009). Aufgrund dieser Ergebnisse wurde vermutet, dass CHD7 eine wichtige Rolle bei der Transkriptionsregulation hat. Es wurde die Hypothese aufgestellt, dass durch CHD7 bzw. CHD7-enthaltende Komplexe der Enhancerbereich in die räumliche Nähe des Promotorbereiches eines Zielgens gebracht wird und dadurch eine Feinmodulierung der Genexpression möglich wird (Schnetz et al. 2009).

Für CHD7 konnte eine Beteiligung in verschiedenen Komplexen nachgewiesen werden: Aufgrund von Studien an embryonalen Mäusestammzellen wird postuliert, dass CHD7 zusammen mit P300, OCT4, SOX2 und Nanog für die Modulation der Genexpression in embryonalen Stammzellen verantwortlich ist (Schnetz et al. 2010). Es ist bekannt, dass CHD7 in humanen multipotenten Zellen der Neuralleiste an Proteine des BAF/PBAF(Brahma assoziierter Faktor/ Polybromo und BRG1 assoziierter Faktor)-Komplexes bindet (Bajpai et al. 2010). Die Neuralleiste stellt eine embryonale Struktur dar, aus der u. a. sowohl Teile des peripheren Nervensystems als auch knöcherne und muskuläre Strukturen des Schädels entstehen. Die BAF- und PBAF-Komplexe zeigen gewebsspezifische Unterschiede in ihrer Zusammensetzung und üben verschiedene Funktionen während der Embryogenese aus (Trotter und Archer 2008, Ho und Crabtree 2010). Sie gehören zur SWI/ SNF-Familie der ATP-abhängigen Chromatin-remodelling-Komplexe.

Als Bestandteil eines weiteren Komplexes reguliert CHD7 die Osteoblastendifferenzierung über die Beeinflussung von Runx2 (runt related transcription factor 2) (Takada et al. 2007, Martin 2010). In diesem Komplex scheint CHD7 eine Ankerfunktion zwischen dem Komplex und der DNA auszuüben. Vermutlich beeinflusst hierbei der Komplex über das Protein HKMT die Transkription durch Methylierung des neunten Lysins am N-terminalen Ende des Histons 3 (Marfella und Imbalzano 2007). 
Bisher hat sich gezeigt, dass CHD7 zellspezifisch eine Komponente in verschiedenen Komplexen ist. In der Vergangenheit wurde das CHARGE-Syndrom wie auch z. B. das DiGeorge-Syndrom zu den Neurocrestopathien gezählt, weil bereits 1985 erkannt wurde, dass bei der Erkrankung Strukturen betroffen sind, die sich aus der Neuralleiste entwickeln (Siebert et al. 1985). Zu den Neurocrestopathien zählen verschiedene Krankheitsbilder, die auf Störungen der Migration und Interaktion von Zellpopulationen der Neuralleiste zurückzuführen sind. Aus der Neuralleiste entwickeln sich u. a. die Ganglienzelllen verschiedener Hirnnerven ( $\mathrm{N}$. oculomotorius, $\mathrm{N}$. trigeminus, $\mathrm{N}$. facialis, $\mathrm{N}$. vestibulocochlearis, N. glossopharyngeus, N. vagus) (Sadler 2003). Schäden in der Ausbildung dieser Ganglienzellen können zu den beim CHARGE-Syndrom auftretenden Symptomen wie z. B. Fazialisparese, Innenohrschwerhörigkeit oder Störungen im Schluckakt führen. Andere Zellen der Neuralleiste sind an der Ausbildung der embryonalen Aortenbögen, des membranösen Teils des Herzseptums, der Semilunarklappen und der regelhaften Anknüpfung der großen Herzgefäße an das Herz beteiligt (Kirby und Waldo 1990, Creazzo et al. 1998). Fehlentwicklungen dieser Strukturen während der Embryogenese können zu komplexen Herzfehlern führen, die beim CHARGE-Syndrom gehäuft auftreten können.

Zum weiteren Verständnis der Pathogenese des CHARGE-Syndroms sollte es Ziel zukünttiger Forschungsprojekte sein, die CHD7-enthaltenden Komplexe weiter zu differenzieren. Außerdem ergibt sich die Fragestellung, welche Gene durch CHD7 selbst oder einen CHD7-enthaltenden Komplex beeinflusst werden und welche Funktion diesen Genen zugeschrieben wird. Sind diese Gene sog. Schlüsselgene für einen in der Embryogenese spezifischen Signalweg?

In unserer Arbeitsgruppe wurde als möglicher Interaktionspartner von CHD7 ein weiteres Mitglied der Subgruppe III gefunden.

\subsubsection{CHD 8}

CHD8 gehört zur Subgruppe III der CHD-Gen-Familie und liegt auf dem Chromosom 14q11.2. Es enthält 38 Exons und kodiert für ein 2302 Aminosäuren umfassendes Protein. In unserer Arbeitsgruppe wurde in einem yeast two hybrid library screen CHD8 als putativer Interaktionspartner von CHD 7 detektiert. Die Interaktion zwischen CHD7 und CHD8 konnte durch verschiedene Methoden wie direktem yeast two hybrid, Co-Immunpräzipitation und bimolekulare Fluoreszenzkomplementation bestätigt werden. Die Ergebnisse lassen die Annahme zu, dass die beiden Proteine sowohl direkt als auch indirekt über Brückenproteine interagieren (Batsukh et al. 2010). 
Bei der Fruchtfliege Drosophila melanogaster gibt es nur ein Gen der CHD-Subgruppe III: kismet. Es ähnelt dem menschlichen CHD7-Gen oder anderen Mitgliedern der Subgruppe III und kodiert bei der Fruchtfliege für zwei Isoformen. Kismet wird auch eine Funktion in der Regulation der Transkription zugeschrieben (Srinivasan et al. 2008, Rodríguez-Paredes et al. 2009). Es wurde die Hypothese aufgestellt, dass die Funktion von kismet beim Menschen auf die CHD-Gene der Subgruppe III (CHD Gene 5-9) aufgeteilt ist (Rodríguez-Paredes et al. 2009).

In der Literatur wird beschrieben, dass CHD8 an den Zink-Finger-Transkriptionsfaktor ZNF143 binden kann (Yuan et al. 2007) und so die Expression von U6-Genen beeinflusst. U6-Gene kodieren für ribosomale RNA, die u. a. als Teil des Spleißosoms für die Entfernung der Introns aus der prä-mRNA und für die anschließende Verknüpfung der Exons verantwortlich ist (Wahl et al. 2009). Dieser Vorgang wird als Spleißen bezeichnet. Weiterhin wirkt CHD8 auf die Expression von beta-Catenin-Zielgenen (Thompson et al. 2008). In vitro bindet CHD8 an dimethylierte Formen des vierten Lysins im Histon 3 (H3K4), und außerdem kontrolliert es die Expression von Cyclin E2 und der Thymidylat-Synthetase (RodríguezParedes et al. 2009). Für murines CHD8 konnte gezeigt werden, dass es an CTCF bindet. CTCF fungiert als Transkriptionsfaktor und kann an Insulatoren binden, die z. B. Enhancer blockieren können (Ishihara et al. 2006).

Außerdem interagiert CHD8 mit dem MLL1 (mixed lineage leukemia)/-WDR5-Komplex. Dieser Komplex ist an der Regulierung von HoxA2 beteiligt. HoxA2 selbst kodiert für einen Transkriptionsfaktor, der besonders wichtig für die Regulation der Zelldifferenzierung und Entwicklung ist. Bei Anwesenheit von CHD8 kommt es zu einer Down-Regulation der HoxA2-Transkription (Yates et al. 2010).

MLL2 kann wie MLL1 auch an den WAR-Komplex binden (Thompson et al. 2008, Dou et al. 2005). Heterozygote Mutationen im MLL2-Gen führen zum Kabuki-Syndrom ( $\mathrm{Ng}$ et al. 2010, Hannibal et al. 2011). Charakteristisch für dieses Dysmorphiesyndrom sind auffällig lange Lidspalten, ein medialer Epikanthus, hohe bogige Augenbrauen mit spärlicher Behaarung im lateralen Drittel, eine breite eingesunkene Nasenspitze, häufig dysplastisch große, abstehende Ohren und eine Lippen-Kiefer-Gaumenspalte. U. a. sind Kinder mit KabukiSyndrom häufig kleinwüchsig, sind mental retardiert und weisen vielfältige Fehlbildungen im Urogenitaltrakt, am Herzen, am Skelett oder an den Augen auf (Niikawa et al. 1981 und 1988, Hannibal et al. 2011). Das heißt, bei dieser Erkrankung zeigen Organsysteme Fehlbildungen, die auch beim CHARGE-Syndrom betroffen sind (Schulz et al. 2014). Es ergibt sich aufgrund der ähnlichen Symptomatik der beiden Syndrome die Frage, ob CHD8 und MLL2 durch die jeweilige Komplexbildung mit dem WAR-Komplex die gleichen Zielgene beeinflussen. 
Über andere Erkrankungen ist bekannt, dass Interaktionspartner eines krankheitsverursachenden Proteins ebenfalls zum selben Phänotyp führen können, wenn ein Defekt im Interaktionspartner vorliegt. Es werden z. B. beim Cornelia-de-Lange-Syndrom hauptsächlich Mutationen in den Cohesin-Regulatoren NIPBL und ESCO2 für die Erkrankung verantwortlich gemacht; aber auch Mutationen in weiteren Komponenten des Cohesin-Komplexes (SMC1A und SMC3) führen zu einem milde ausgeprägten Phänotyp (Deardorff et al. 2007).

So wurde CHD8 als Kandidatengen für die Entstehung des CHARGE-Syndroms postuliert. Die Untersuchung von 25 CHD7-negativen CHARGE-Patienten erbrachte keinen Nachweis von Mutationen im CHD8-Gen (s. 3.2.1). Neale et al. (2012) sowie O'Roak et al. (2012) beschrieben de novo- missense- sowie loss of function-Mutationen im CHD8-Gen bei an Autismus erkrankten Patienten. Betroffene CHARGE-Patienten zeigen in über 2/3 der Fälle auch autistische Verhaltensweisen (Betancur 2011). Somit wird die Hypothese unterstützt, dass ein CHD7- und CHD8-enthaltender Proteinkomplex bestimmte zellspezifische Zielgene reguliert. Im Rahmen der Forschungsarbeit wurde ein weiteres Gen entdeckt, welches einen Interaktionspartner von CHD7 in diesem Proteinkomplex darstellen könnte.

\subsection{FAM124B}

In der Arbeitsgruppe wurde mithilfe von SILAC (stable isotope labeling by amino acids in cell culture) das Protein Fam124B entdeckt, welches in einem CHD7- und CHD8-enthaltenden Komplex zu finden ist (Batsukh et al. 2012). Über die möglichen Funktionen von FAM124B im Organismus liegen keine Publikationen vor.

Fam124B gibt es z. B. bei Schimpanse, Hund, Kuh, Maus, Ratte, Huhn, Zebrafisch und weiteren Spezies. Das humane FAM124B liegt auf dem Chromosom 9 (9q33.3).

Bei der Maus konnte die Expression von Fam124B in verschiedenen Geweben wie Gehirn, Herz, Niere, Lunge und Hoden nachgewiesen werden, also in Organen, die auch beim CHARGE-Syndrom betroffen sein können (Batsukh et al. 2012). Die Expressionsanalyse für FAM124B in verschiedenen menschlichen Organen ist deshalb sinnvoll.

Beim Menschen sind zwei Isoformen bekannt: Isoform a, aus Exon 1 und 3 bestehend, und Isoform b mit Exon 1 und 2. Die Isoform a entspricht weitgehend dem murinen Transkript. FAM124B wurde im Rahmen eines Kandidatengenscreenings getestet.

Es konnten zwar keine pathogenen Mutationen bei der Sequenzanalyse von FAM124B (s. 3.2.2) nachgewiesen werden, doch ist die Testung von weiteren CHD7-negativen CHARGE- 
Patienten angezeigt, da möglicherweise nur bei einem kleinen Prozentsatz der CHARGEPatienten eine FAM124B-Mutation ursächlich für die Symptomatik ist. Weiterhin sind Funktionsstudien zum Fam124B notwendig, um eine mögliche Rolle in der Pathogenese des CHARGE-Syndroms zu erfassen.

\subsection{FAM124B-Polymorphismus im Exon 3, c.612C>T}

In der Genetik wird von einem Polymorphismus gesprochen, wenn innerhalb einer Population ein oder mehrere Allele der gleichen Gensequenz vorliegen. Dabei muss die Allelfrequenz in dieser Population grösser als $1 \%$ sein. Ansonsten spricht der Genetiker von dem Vorliegen einer Mutation.

Im vorliegenden Fall waren ein CHARGE-Patient und 2 Goldenhar-Patienten heterozygot CT im Exon 3 an der Stelle c.612. Die Untersuchung der Wildtyp-Kontrollen zeigte, dass dieser Nukleotidaustausch auch in der gesunden Population mit einer Wahrscheinlichkeit von $10 \%$ heterozygot vorliegt. Es ergibt sich die Frage, wieso in den Wildtyp-Kontrollen keine Homozygotie TT vorkommt. Einerseits kann die Anzahl der Kontrollen zu gering sein, andererseits ist es denkbar, dass solche Menschen Symptome aufweisen und daher nicht in einem Kollektiv gesunder Personen zu finden sind.

\subsection{Ursachen für die Entstehung von Neumutationen}

Neumutationen sind Mutationen, die in den Keimzellen der Eltern oder in den Körperzellen spontan entstehen. Beim CHARGE-Syndrom liegen in der Mehrzahl der Fälle solche de novo-Mutationen vor. Nur wenige familiäre Fälle sind in der Literatur beschrieben, bei denen ein Elternteil entweder ebenfalls ein CHARGE-Syndrom in milder Ausprägung, ein somatisches Mosaik oder ein Gonadenmosaik aufweist (Lalani et al. 2006, Jongmans et al. 2006 und 2008, Delahaye et al. 2007, Wincent et al. 2008, Pauli et al. 2009). Die im Rahmen dieser Arbeit erhaltenen Ergebnisse zeigen, dass in 12 von 13 sporadischen Fällen (92,3\%) eine Mutation im CHD7-Gen das paternale Allel betrifft (s. 3.3.1). Bei dem Patienten mit der Indexnummer 12 betrifft die Mutation c.3059T>C hingegen das maternale Allel. Ob es sich bei diesem Fall möglicherweise nicht um eine de novo-Mutation handelt, sondern die Mutter ein Gonadenmosaik aufweist, kann nicht ausgeschlossen werden. Insgesamt zeigte sich jedoch, dass es sich beim CHARGE-Syndrom um eine Erkrankung handelt, bei der die Mutationen überwiegend in der männlichen Keimbahn entstehen (Pauli et al. 2012). 
Bei zahlreichen weiteren autosomal dominant vererbten Erkrankungen konnte ebenfalls eine Zuordnung der jeweiligen Mutation zum väterlichen Allel gemacht werden (s. Tabelle 4.1). So wurde z. B. für Neumutationen im FGFR2-Gen, welche für das Apert-, Crouzon- oder Pfeiffer-Syndrom verantwortlich gemacht werden, ausschließlich die paternale Herkunft nachgewiesen (Moloney et al. 1996, Glaser et al. 2000). Auch Mutationen im FGFR3-Gen, welche zur klinischen Ausprägung der Achondroplasie führen, liegen nur im paternalen Allel (Wilkin et al. 1998). Ebenso konnte beim Noonan-Syndrom die rein paternale Herkunft von de novo- Mutationen im PTPN11-Gen belegt werden (Tartaglia et al. 2004).

\begin{tabular}{|l|c|c|c|}
\hline Vererbbare Krankheiten & paternal & maternal & Alterseffekt \\
\hline Apert-Syndrom & $\mathrm{X}$ & & $\mathrm{X}$ \\
\hline Achondroplasie & $\mathrm{X}$ & & $\mathrm{X}$ \\
\hline Crouzon-Syndrom & $\mathrm{X}$ & & $\mathrm{X}$ \\
\hline Pfeiffer-Syndrom & $\mathrm{X}$ & & $\mathrm{X}$ \\
\hline Multiple endokrine Neoplasie 2A & $\mathrm{X}$ & $\mathrm{X}$ \\
\hline Noonan-Syndrom & $\mathrm{X}$ & $\mathrm{X}$ & \\
\hline Tuberöse Sklerose & $\mathrm{X}$ & $\mathrm{X}$ & \\
\hline Neurofibromatose 2 & $\mathrm{X}$ & $\mathrm{X}$ & \\
\hline Keratitis-Ichthyosis-Taubheitssyndrom & $\mathrm{X}$ & $\mathrm{X}$ & \\
\hline Campomelie-Dysplasie & $\mathrm{X}$ & $\mathrm{X}$ & \\
\hline Timothy-Syndrom & $\mathrm{X}$ & $\mathrm{X}$ & \\
\hline Townes-Brocks-Syndrom & $\mathrm{X}$ & \\
\hline Hippel-Lindau-Syndrom & $\mathrm{X}$ & \\
\hline RETT-Syndrom (XR) & & & \\
\hline
\end{tabular}

Tab 4.1: Auswahl von autosomal dominant und X-chromosomal vererbten Krankheitsbildern: Nachweis von Mutationen im paternalen oder maternalen Allel [XR]: $x$-chromosomal rezessiv. Die anderen genannten Erkrankungen werden autosomal dominant vererbt (Mulligan et al.1994, Richards et al.1995, Cameron et al. 1996, Moloney et al. 1996, Wohllk et al. 1996, Schuffenecker et al. 1997, Wilkin et al. 1998, Glaser et al. 2000, Trappe et al. 2001, Tiemann-Boege et al. 2002, Splendore et al. 2003, Engel et al. 2004, Splawski et al. 2004, Tartaglia et al. 2004, Böhm et al. 2006, MazereeuwHautier et al. 2007). 
Auch für die Multiple Endokrine Neoplasie 2A (MEN 2A) konnte in insgesamt 10 untersuchten Familien die paternale Herkunft von Neumutationen im RET-Protoonkogen gezeigt werden (Mulligan et al. 1994, Wohllk et al. 1996, Schuffenecker et al. 1997). Für andere autosomal dominant vererbte Krankheiten wie das Townes-Brocks-Syndrom konnte nachgewiesen werden, dass die de novo-Mutationen vorwiegend im paternalen Allel liegen (Böhm et al. 2006).

Bisher sind keine Erkrankungen bekannt, bei denen de novo-Mutationen ausschließlich das maternale Allel betreffen.

Daher wurde nach verschiedenen Erklärungen für das bevorzugte Auftreten von de novoMutationen im paternalen Allel gesucht. Beim Mann hat sich eine Spermatogonie bis zur Pubertät 30-mal geteilt und danach 23-mal pro Jahr. Bis zur endgültigen Entstehung eines Spermiums erfolgen weitere Teilungen. Je älter ein Mann ist, desto mehr Zellteilungen sind in den Spermatogonien bereits erfolgt. So gehen z. B. die Spermien eines 20-jährigen Mannes aus 150 Zellteilungen und DNA-Replikationen hervor, bei einem 40-jährigen aus 610 Zellteilungen (Engel et al. 2004). Da es in der Spermatogenese viel mehr Zellteilungen im Vergleich zur Oogenese gibt, bei der die Eizellen von Geburt an in ihrer gesamten Zahl angelegt sind, vermutete Penrose bereits 1955, dass Neumutationen gehäuft in männlichen Keimzellen vorkommen, da während der Replikation Kopierfehler auftreten können (Penrose 1955). In der Regel werden solche Kopierfehler durch verschiedene Reparaturmechanismen erfolgreich behoben oder die betroffene Zelle wird in die Apoptose, den programmierten Zelltod, geführt (Engel et al. 2004). Aufgrund abnehmender Reparaturkapazitäten des alternden Mannes würden die Mutationen in den Spermien im Verlauf des Lebens akkumulieren und so zu einem linearen Anstieg und einem paternalen Alterseffekt führen. Zum einen zeigte sich jedoch, dass der Alterseffekt nicht linear, sondern exponentiell ansteigt, zum anderen gibt es Erkrankungen, bei denen zwar die Mutationen das paternale Allel betreffen, aber ein Alterseffekt nicht zu beobachten ist (Arnheim und Calabrese 2009). Daraus ergibt sich, dass es weitere Faktoren geben muss, die einen Einfluss auf die Entstehung von Neumutationen in der männlichen Keimbahn haben.

Es ist bekannt, dass die Spermien-DNA einen höheren Methylierungsgrad aufweist als die DNA der Eizellen (Driscoll und Migeon 1990). Sog. CpG-Inseln (Cyytosin-phosphatidylGuanin), die u. a. Teil der epigenetischen Genregulation darstellen, sind sehr empfindlich gegenüber spontaner Deamination zu Thymidinen (Duncan und Miller 1980). Solche Fehler werden häufig toleriert und eine Mutation ist entstanden. Die Mutationen in den Familien mit der Indexnummer 1, 4, 7 und 8 zeigen jeweils einen Austausch von Cytosin zu Thymin und liegen jeweils auf dem paternalen Allel; hiermit unterstützen sie diese Hypothese (Pauli et al. 2012). 
Auch der verstärkte Methylierungsgrad im paternalen X-Chromosom im Vergleich zum XChromosom in der Oozyte wird bei X-chromosomal dominant vererbten Erkrankungen, wie z. B. für das Rett-Syndrom, als mögliche Ursache für eine erhöhte Rate an Neumutationen in den männlichen Keimzellen gesehen (Goto und Monk 1998). In 26 von 27 Fällen konnten Trappe et al. einen paternalen Ursprung von Neumutationen im MECP2-Gen nachweisen (Trappe et al. 2001).

Als weitere Ursache für die Lokalisation der Mutation im väterlichen Allel wird ein Selektionsvorteil der mutierten Spermien gegenüber den gesunden Spermien postuliert. Dies wurde in der Vergangenheit vor allem bei Gain-of-function-Mutationen beobachtet. So führen z. B. beim Noonan-Syndrom Mutationen im PTPN11-Gen, die ca. 50\% der für diese Erkrankung verantwortlichen Mutationen ausmachen (Tartaglia et al. 2001), zu einer erhöhten Signaltransduktion über den Ras-MAP-Kinase-Weg (Tartaglia et al. 2004). Die MAP-Kinasen stellen eine Familie von Kinasen dar, die zu einer Aktivierung von bestimmten Genen führen, welche die Proliferation und Differenzierung von Zellen oder die Apoptose beeinflussen (Robinson und Cobb 1997). Auch den in der Literatur beschriebenen Mutationen im FGFR2- und FGFR3-Gen, die zur Ausprägung des Apert-, Crouzon-, PfeifferSyndrom und der Achondroplasie führen, wird ein Selektionsvorteil gegenüber gesunden Spermien zugeschrieben (Glaser et al. 2003, Goriely et al. 2003). Es wird vermutet, dass die mutierten Spermien besonders in ihrer Motilität und der Kapazitation den nicht mutierten Spermien überlegen sind (Glaser und Jabs 2004).

Ob Mutationen im CHD7-Gen für die betroffenen Spermien ebenfalls einen Selektionsvorteil bewirken, ist bisher unklar.

\subsection{Alterseffekte}

Es ist allgemein bekannt, dass insbesondere in den Industriestaaten das Alter der Eltern bei Zeugung eines Kindes in den letzten Jahrzehnten durch den Fortschritt der Medizin angestiegen ist. Diese Entwicklung birgt aber gewisse Gefahren in sich, da mit Zunahme des Alters der Frau das Risiko für die Geburt eines Kindes mit einer Chromosomenanomalie steigt, während beim Mann mit zunehmenden Alter das Risiko für das Auftreten von Neumutationen in der Keimbahn steigt.

\subsubsection{Paternales Alter}

In der Literatur konnte für verschiedene Erkrankungen eine Abhängigkeit vom paternalen Alter nachgewiesen werden. Dieses sind zum großen Teil Daten, die sich auf autosomal dominante oder X-chromosomal rezessive Neumutationen beziehen (s. Tabelle 4.1). So 
konnte z. B. für die Achondroplasie, das Apert-, das Crouzon- oder auch das PfeifferSyndrom, MEN2A und 2B ein paternaler Alterseffekt belegt werden (Carlson et al. 1994, Schuffenecker et al. 1997, Wilkin et al. 1998, Glaser et al. 2000 und 2003, Tiemann-Boege et al. 2002).

Daher sollte im Rahmen der Doktorarbeit geprüft werden, ob es beim CHARGE-Syndrom ebenfalls einen paternalen Alterseffekt gibt. In der Untersuchung der 30 CHARGE-Patienten konnte kein erhöhtes väterliches Zeugungsalter nachgewiesen werden. Im Mittel waren die Väter bei Zeugung 32.92+/-5.14 Jahre alt. Verglichen mit Daten des Statistischen Bundesamtes Deutschland waren die Männer 33.89 Jahre im Jahr 2003 (Statistisches Bundesamt 2010). Es zeigt sich also kein signifikanter Unterschied zwischen dem väterlichen Alter unserer Kohorte und der allgemeinen männlichen deutschen Population.

In der Literatur wurde zuvor ein erhöhtes väterliches Zeugungsalter beim CHARGE-Syndrom durch Tellier et al. (1996) beschrieben. Die Auswahl der Patienten mit CHARGE-Syndrom erfolgte ausschließlich nach klinischen Kriterien. Mutationsanalysen waren damals nicht möglich. Es ist daher zu vermuten, dass in das Kollektiv von Tellier et al. (1996) auch Patienten mit anderen Erkrankungen eingeflossen sind und der festgestellte Alterseffekt zufällig ist.

\subsubsection{Maternales Alter}

Für das Auftreten von numerischen Chromosomenaberrationen wie z. B. bei der Trisomie 21 ist bereits seit 1933 bekannt, dass das Risiko mit zunehmendem Alter der Mutter bei Zeugung ansteigt (Penrose 1933 und 1934). Während bei einer Frau im Alter von 20 Jahren das Risiko 1/1500 beträgt, steigt es bis zum 45.Lebensjahr auf 1/30. Zur Erklärung dieser Tatsache wurden bisher verschiedene Hypothesen aufgestellt: Während die Oozyten bis zur Befruchtung in einer langen Ruhephase verweilen, können sich Chiasmata vorzeitig lösen. Die homologen Chromosomen können als solche nicht mehr erkannt werden, und es kann eine Fehlverteilung der Chromosomen folgen. Am häufigsten werden hierbei die homologen Chromosomen nicht geteilt (Buselmaier und Tariverdian 2006).

Als mögliche Auslöser für meiotisches Non-disjunction werden Faktoren wie die Akkumulation von toxischen Effekten bei der alternden Frau oder die erhöhte Wahrscheinlichkeit für mitochondriale Mutationen verantwortlich gemacht (Jansen und De Boer 1998, Van Blerkom et al. 1998, Schon et al. 2000).

Wie auch für andere autosomal dominante Erkrankungen konnte ein maternaler Alterseffekt ebenso in unserer Kohorte für das CHARGE-Syndrom nicht gezeigt werden. Das mütterliche Alter unserer Kohorte war 29 +/-4.26 Jahre. Verglichen mit Werten des Statistischen 
Bundesamtes aus dem Jahr 2003 waren Frauen zum Zeitpunkt der Geburt eines Kindes 29.86 Jahre alt (Statistisches Bundesamt 2010).

Zusammenfassend konnte im Rahmen dieser Arbeit gezeigt werden, dass die zum CHARGE-Syndrom führenden CHD7-Mutationen bevorzugt in der männlichen Keimbahn entstehen. Es konnte weder ein maternaler noch ein paternaler Alterseffekt beobachtet werden. Zudem wurde vermutet, dass mehrere Mechanismen zur Mutationsentstehung in der männlichen Keimbahn beitragen. Für einen Teil der Patienten ist die Hypermutabilität der methylierten CpG-Inseln der Spermien-DNA ein möglicher Grund. Weitere Studien sind nötig, um die einzelnen Mechanismen genau zu charakterisieren. Insbesondere die Frage nach einem Selektionsvorteil für Spermatogonien mit einer CHD7-Mutation bleibt zu klären. 


\section{$5 \quad$ Literaturverzeichnis}

Arnheim N, Calabrese P (2009): Understanding what determines the frequency and pattern of human germline mutations. Nat Rev Genet 10(7), 478-488.

Bajpai R, Chen DA, Rada-Iglesias A, Zhang J, Xiong Y, Helms J, Chang CP, Zhao Y, Swigut T, Wysocka J (2010): CHD 7 cooperates with PBAF to control multipotent neural crest formation. Nature $\underline{463}, 958-962$.

Bartels CF, Scacheri C, White L, Scacheri PC, Bale S (2010): Mutations in the CHD7 Gene: The Experience of a Commercial Laboratory. Genet Test Mol Biomarkers 14(6), 881891.

Batsukh T, Pieper L, Koszucka AM, von Velsen N, Hoyer-Fender S, Elbracht M, Bergman JE, Hoefsloot LH, Pauli S (2010): CHD8 interacts with CHD7, a protein which is mutated in CHARGE syndrome. Hum Mol Genet 19(14), 2858-2866.

Batsukh T, Schulz Y, Wolf S, Rabe TI, Oellerich T, Urlaub H, Schaefer IM, Pauli S (2012): Identification and characterization of FAM124B as a novel component of a CHD7 and CHD8 containing complex. PloS One $\underline{7(12)}$, e52640.

Becker PB, Hörz W (2002): ATP-dependent nucleosome remodeling. Annu Rev Biochem $\underline{71}, 247-273$.

Bergman JE, Janssen N, Hoefsloot LH, Jongmans MC, Hofstra RM, van RavenswaaijArts CM (2011): CHD7 mutations and CHARGE syndrome: the clinical implications of an expanding phenotype, J Med Genet 48(5), 334-342.

Betancur C (2011): Etiological heterogeneity in autism spectrum disorders: more than 100 genetic and genomic disorders and still counting. Brain Res 1380, 42-77.

Blake KD, Davenport SL, Hall BD, Hefner MA, Pagon RA, Williams MS, Lin AE, Graham JM Jr. (1998): CHARGE association: an update and review for the primary pediatrician. Clin Pediat $\underline{37}, 159-173$. 
Böhm J, Munk-Schulenburg S, Felscher S, Kohlhase J (2006): SALL1 mutations in sporadic Townes-Brocks syndrome are of predominantly paternal origin without obvious paternal age effect. Am J Med Genet A 140(18), 1904-1908.

Bosman EA, Penn AC, Amborse JC, Kettleborough R, Stemple DL, Steel KP (2005): Multiple mutations in mouse Chd7 provide models fro CHARGE syndrome. Hum Mol Genet 14, 3463-3476.

Buselmaier W, Tariverdian G: Humangenetik für Biologen. Springer Verlag, Heidelberg 2006, S. $110 f$.

Cameron FJ, Hageman RM, Cooke-Yarborough C, Kwok C, Goodwin LL, Sillence DO, Sinclair AH (1996): A novel germ line mutation in SOX9 causes familial campomelic dysplasia and sex reversal. Hum Mol Genet 5(10), 1625-1630.

Carlson KM, Bracamontes J, Jackson CE, Clark R, Lacroix A, Wells SA Jr, Goodfellow PJ (1994): Parent-of-origin effects in multiple endocrine neoplasia type 2B. Am J Hum Genet $\underline{55(6)}, 1076-1082$.

Creazzo TL, Godt RE, Leatherbury L, Conway SJ, Kirby ML (1998): Role of cardiac neural crest cells in cardiovascular development. Annu Rev Physiol $\underline{60}$, 267-286.

Deardorff MA, Kaur M, Yaeger D, Rampuria A, Korolev S, Pie J, Gil-Rodríguez C, Arnedo M, Loeys B, Kline AD (2007): Mutations in Cohesin Complex Members SMC3 and SMC1A Cause a Mild Variant of Cornelia de Lange Syndrome with Predominant Mental Retardation. Am J Hum Genet 80(3), 485-494.

Delahaye A, Sznajer Y, Lyonnet S, Elmaleh-Bergès M, Delpierre I, Audollent S, WienerVacher S, Mansbach AL, Amiel J, Baumann C (2007): Familial CHARGE syndrome because of CHD7 mutation: clinical intra-and interfamilial variability. Clin Genet $\underline{72(2)}$, 112121.

Den Dunnen JT, Antonarakis SE (2000): Mutation Nomenclature Extensions and Suggestios to Describe Complex Mutations: A Discussion. Hum Mutat 15(1), 7-12. 
Dou Y, Milne TA, Tackett AJ, Smith ER, Fukuda A, Wysocka J, Allis CD, Chait BT, Hess JL, Roeder RG (2005): Physical association and coordinate function of the H3 K4 methyltransferase MLL1 and H4 K16 acetyltransferase MOF. Cell 121(6), 873-885.

Driscoll DJ, Migeon BR (1990): Sex difference in methylation of single-copy genes in human meiotic germ cells: implications for $X$ chromosome inactivation, parental imprinting, and origin of CpG mutations. Somat Cell Mol Genet 16(3), 267-282.

Duncan BK, Miller JH (1980): Mutagenic deamination of cytosine residues in DNA. Nature 287(5782), 560-561.

Engel W, Sancken U, Laccone F (2004): Das väterliche Alter aus humangenetischer Sicht. J Reproduktionsmed Endokrinol 1(4), 263-267.

Flaus A, Martin DM, Barton GJ, Owen-Hughes T (2006): Identification of multiple distinct Snf2 subfamilies with conserved structural motifs. Nucleic Acids Res $\underline{31}$, 2887-2905.

Glaser RL, Jabs EW (2004): Dear old dad. Sci Aging Knowledge Environ (3), re1.

Glaser RL, Jiang W, Boyadjiev SA, Tran AK, Zachary AA, Van Maldergem L, Johnson D, Walsh S, Oldridge M, Wall SA (2000): Paternal origin of FGFR2 mutations in sporadic cases of Crouzon syndrome and Pfeiffer syndrome. Am J Hum Genet 66(3), 768-777.

Glaser RL, Broman KW, Schulman RL, Eskenazi B, Wyrobek AJ, Jabs EW (2003): The paternal-age effect in Apert syndrome is due, in part, to the increased frequency of mutations in sperm. Am J Hum Genet 73(4), 939-947.

Goriely A, Mc Vean GA, Röjmyr M, Ingemarsson B, Wilkie AO (2003): Evidence for selective advantage of pathogenic FGFR2 mutations in the male germ line. Science 301(5633), 643-646.

Goto T, Monk M (1998): Regulation of X-chromosome inactivation in development in mice and humans. Microbiol Mol Biol Rev $\underline{62}, 362-378$. 
Hall BD (1979): Choanal atresia and associated multiple anomalies. J Pediatr $\underline{95}$, 395-398.

Hall JA, Georgel PT (2007): CHD proteins: a diverse family with strong ties. Biochem Cell Biol 85(4), 463-476.

Hanahan D: Techniques for transformation of E. coli. In: Glover DM (ed.): DNA cloning: a practical approach. Vol. 1 Mc Lean, IRL Press, Oxford 1985, 109-135.

Hannibal MC, Buckingham KJ, Ng SB, Ming JE, Beck AE, McMillin MJ, Gildersleeve HI, Bigham AW, Tabor HK, Mefford HC (2011): Spectrum of MLL2 (ALR) mutations in 110 cases of Kabuki syndrome. Am J Med Genet A 155A(7), 1511-1516.

Hittner HM, Hirsch NJ, Kreh GM, Rudolph AJ (1979): Colobomatous microphthalmia, heart disease, hearing loss, and mental retardation - a syndrome. J. Pediatr Ophthalmol Strabismus 16(2), 122-128.

Ho L, Crabtree GR (2010): Chromatin remodelling during development. Nature $\underline{463(7280)}$, 474-484

Ishihara K, Oshimura M, Nakao M (2006): CTCF-dependent chromatin insulator is linked to epigenetic remodeling. Mol Cell 23(5), 733-742.

Issekutz KA, Grahman JM Jr, Prasad C, Smith IM, Blake KD (2005): An epidemiological analysis of CHARGE Syndrome: preliminary results from a Canadian study. Am J Med Genet A 133A(3), 309-317.

Jansen RP, De Boer K (1998): The bottleneck: mitochondrial imperatives in oogenesis and ovarian follicular fate. Mol Cell Endocrinol $\underline{145}$, 81-88.

Janssen N, Bergman JE, Swertz MA, Tranebjaerg L, Lodahl M, Schoots J, Hofstra RM, van Ravenswaaij-Arts CM, Hoefsloot LH (2012): Mutation update on the CHD7 gene involved in CHARGE syndrome. Hum Mutat $\underline{8}$, 1149-1160. 
Jongmans MC, Admiraal RJ, van der Donk KP, Vissers LE, Baas AF, Kapusta L, van Hagen JM, Donnai D, de Ravel TJ, Veltman JA (2006): CHARGE syndrome: the phenotypic spectrum of mutations in the CHD7 gene. J Med Genet $\underline{43}$, 306-314.

Jongmans MC, Hoefsloot LH, van der Donk KP, Admiraal RJ, Magee A, van de Laar I, Hendriks Y, Verheij JB, Walpole I, Brunner HG (2008): Familial CHARGE-Syndrome and the CHD7 gene: a recurrent missense mutation, intrafamilial recurrence and variability. Am $\mathrm{J}$ Med Genet A $146 \mathrm{~A}, 43-50$.

Kirby ML, Waldo K (1990): Role of neural crest in congenital heart disease. Circulation $\underline{82(2)}, 332-340$.

Koh FM, Sachs M, Guzman-Ayala M, Ramalho-Santos M (2010): Parallel gateways to pluripotency: open chromatin in stem cells and development. Curr Opin Genet Dev 20(5), 492-499.

Lalani SR, Safiullah AM, Fernbach SD, Harutyunyan KG, Thaller C, Peterson LE, McPherson JD, Gibbs RA, White LD, Hefner M (2006): Spectrum of CHD7 mutations in 110 individuals with CHARGE syndrome and genotype-phenotype correlation. Am J Hum Genet 78(2), 303-314.

Marfella CG, Imbalzano AN (2007): The Chd family of chromatin remodelers. Mutat Res $\underline{618}, 30-40$.

Martin DM (2010): Chromatin remodeling in development and disease: focus on CHD7. PLoS Genet 6(7), e1001010.

Mazereeuw-Hautier J, Bitoun E, Chevrant-Breton J, Man SY, Bodemer C, Prins C, Antille C, Saurat JH, Atherton D, Harper JI (2007): Keratitis-ichthyosis-deafness syndrome: disease expression and spectrum of connexin 26 (GJB2) mutations in 14 patients. Br J Dermatol 156(5), 1015-1019.

Moloney DM, Slaney SF, Oldridge M, Wall SA, Sahlin P, Stenman G, Wilkie AO (1996): Exclusive paternal origin of new mutations in Apert syndrome. Nat Genet 13 (1), 48-53. 
Mulligan LM, Eng C, Healey CS, Clayton D, Kwok JB, Gardner E, Ponder MA, Frilling A, Jackson CE, Lehnert H (1994): Specific mutations of the RET proto-oncogene are related to disease phenotype in MEN 2A and FMTC. Nat Genet $\underline{6(1)}, 70-74$.

Mullis KB, Faloona F (1987): Specific synthesis of DNA in vitro via a polymerase-catalyzed chain reaction. Methods Enzymol 155, 335-350.

Neale BM, Kou Y, Liu L, Ma'ayan A, Samocha KE, Sabo A, Lin CF, Stevens C, Wang LS, Makarov V (2012): Patterns and rates of exonic de novo mutations in autism spectrum disorders. Nature $\underline{485(7397)}$, 242-245.

Ng SB, Bigham AW, Buckingham KJ, Hannibal MC, McMillin MJ, Gildersleeve HI, Beck AE, Tabor HK, Cooper GM, Mefford HC (2010): Exome sequencing identifies MLL2 mutations as a cause of Kabuki syndrome. Nat Genet 42(9), 790-793.

Niikawa N, Matsuura N, Fukushima Y, Ohsawa T, Kajii T (1981): Kabuki make-up syndrome: a syndrome of mental retardation, unusual facies, large and protruding ears, and postnatal growth deficiency. J Pediat 99(4), 565-569.

Niikawa N, Kuroki Y, Kajii T, Matsuura N, Ishikiriyama S, Tonoki H, Ishikawa N, Yamada Y, Fujita M, Umemoto H (1988): Kabuki make-up (Niikawa-Kuroki) syndrome: a study of 62 patients. Am J Med Genet 31(3), 565-589.

O'Roak BJ, Vives L, Girirajan S, Karakoc E, Krumm N, Coe BP, Levy R, Ko A, Lee C, Smith JD (2012): Sporadic autism exomes reveal a highly interconnected protein network of de novo mutations. Nature 485(7397), 246-250.

Pagon RA, Graham JM Jr, Zonana J, Yong SL (1981): Coloboma, congenital heart disease, and choanal atresia with multiple anomalies: CHARGE association. J Pediatr $\underline{\text { 99(2), }}$ 223-227.

Pauli S, Pieper L, Häberle J, Grzmil P, Burfeind P, Steckel M, Lenz U, Michelmann HW (2009): Proven germline mosaicism in a father of two children with CHARGE syndrome. Clin Genet $\underline{75}$, 473-479. 
Pauli S: Die funktionelle Rolle des CHD7-Proteins - Einblicke in aktuelle Forschungsarbeiten. In: Das CHARGE-Syndrom. Ein Fachbuch für Mediziner, Pädagogen, Therapeuten, Eltern und Betroffene. 2. Auflage; Median Verlag, Heidelberg 2010, 21-29.

Pauli S, von Velsen N, Burfeind P, Steckel M, Mänz J, Buchholz A, Borozdin W, Kohlhase $\mathbf{J}$ (2012): CHD7 mutations causing CHARGE syndrome are predominantly of

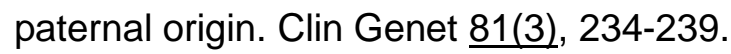

Penrose LS (1933): The relative effect of paternal and maternal age in mongolism. J Genet $\underline{27}, 219-224$.

Penrose LS (1934): The relative aetiological importance of birth order and maternal age in mongolism. Proceedings of the Royal Society (Biology) 115, 431-450.

Penrose L (1955): Parental age and mutation. Lancet 269(6885), 312-313.

Pray-Grant MG, Daniel JA, Schieltz D, Yates JR 3 ${ }^{\text {rd }}$, Grant PA (2005): Chd 1 chromodomain links histone H3 methylation with SAGA-and SLIK-dependent acetylation. Nature 27, 434-438.

Richards FM, Payne SJ, Zbar B, Affara NA, Ferguson-Smith MA, Maher ER (1995): Molecular analysis of de novo germline mutations in the von Hipel-Lindau disease gene. Hum Mol Genet 3(11), 2139-2143.

Robinson MJ, Cobb MH (1997): Mitogen-activated protein kinase pathways. Curr Opin Cell Biol 9(2), 180-186.

Rodríguez-Paredes M, Ceballos-Chávez M, Esteller M, García-Domínguez M, Reyes JC (2009): The chromatin remodeling factor CHD8 interacts with the elongating RNA polymerase II and controls expression of the cyclin E2 gene. Nucleic Acids Res $\underline{37}, 2449$ 2460.

Sadler, TW: Medizinische Embryologie, 10.Auflage; Thieme, Stuttgart 2003, S. 420-422. 
Saha A, Wittmeyer J, Cairns BR (2006): Chromatin remodelling: the industrial revolution of DNA around histones. Nat Rev Mol Cell Biol $\underline{7}$, 437-447.

Sambrook J, Fritsch EF, Maniatis T: Molecular cloning: a laboratory manual. 2nd edn; Cold Spring Harbor Laboratory Press, Cold Spring Harbor, New York 1989.

Sanger F, Nicklen S, Coulson AR (1977): DNA sequencing with chain-terminating inhibitors. Proc Natl Acad Sci USA 74(12), 5463-5467.

Sanlaville D, Etchevers HC, Gonzales M, Martinovic J, Clément-Ziza M, Delezoide AL, Aubry MC, Pelet A, Chemouny S, Cruaud C (2006): Phenotypic spectrum of CHARGE syndrome in fetuses with CHD7 truncating mutations correlates with expression during human development. J Med Genet 43(3), 211-217.

Schnetz MP, Bartels CF, Shastri K, Balasubramanian D, Zentner GE, Balaji R, Zhang X, Song L, Wang Z, LaFramboise T (2009): Genomic distribution of CHD7 on Chromatin tracks H3K4 Methylation patterns. Genom Res $\underline{19}$, 590-601.

Schnetz MP, Handoko L, Akhtar-Zaidi B, Bartels CF, Pereira CF, Fisher AG, Adams DJ, Flicek P, Crawford GE, Laframboise T (2010): CHD7 targets active gene enhancer elements to modulate ES cell-specific gene expression. PloS Genet $\underline{6(7)}$, e1001023.

Schon EA, Kim SH, Ferreira JC, Magalhães P, Grace M, Warburton D, Gross SJ (2000): Chromosomal non-disjunction in human oocytes: is there a mitochondrial connection? Hum Reprod 15 Suppl 2, 160-172.

Schuffenecker I, Ginet N, Goldgar D, Eng C, Chambe B, Boneu A, Houdent C, Pallo D, Schlumberger M, Thivolet C (1997): Prevalence and parental origin of de novo RET mutations in multiple endocrine neoplasia type $2 \mathrm{~A}$ and familial medullary thyroid carcinoma. Am J Hum Genet 60(1), 233-237. 
Schulz Y, Freese L, Mänz J, Zoll B, Völter C, Brockmann K, Bögershausen N, Becker J, Wollnik B, Pauli S (2014): CHARGE and Kabuki syndromes: a phenotypic and molecular link. Hum Mol Genet 23(16), 4396-4405.

Siebert JR, Graham JM Jr, MacDonald C (1985): Pathologic features of the CHARGE association: support for involvement of the neural crest. Teratology $\underline{31(3)}$, 331-336.

Smeenk G, Wiegant WW, Vrolijk H, Solari AP, Pastink A, van Attikum H (2010): The NuRD chromatin-remodeling complex regulates signaling and repair of DNA damage. J Cell Biol 190(5), 741-749.

Splawski I, Timothy KW, Sharpe LM, Decher N, Kumar P, Bloise R, Napolitano C, Schwartz PJ, Joseph RM, Condouris K (2004): Ca(V)1.2 calcium channel dysfunction causes a multisystem disorder including arrhythmia and autism. Cell 119(1), 19-31.

Splendore A, Jabs EW, Félix TM, Passos-Bueno MR (2003): Parental origin of mutations in sporadic cases of Treacher Collins syndrome. Eur J Hum Genet 11(9), 718-722.

Srinivasan S, Dorighi KM, Tamkun JW (2008): Drosophila Kismet regulates histone H3 lysine 27 methylation and early elongation by RNA polymerase II. PLoS Genet $\underline{4(10)}$, e1000217.

Statistisches Bundesamt (2010): Durchschnittliches Alter der Eltern bei der Geburt ihrer lebendgeborenen Kinder nach der Legitimität 1991-2009. Wiesbaden. Auf Anfrage am 18.01.2011 per email erhalten.

Takada I, Mihara M, Suzawa M, Ohtake F, Kobayashi S, Igarashi M, Youn MY, Takeyama K, Nakamura T, Mezaki Y (2007): A histone lysine methyltransferase activated by non-

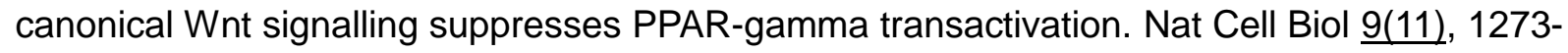
1285. 
Tartaglia M, Mehler EL, Goldberg R, Zampino G, Brunner HG, Kremer H, van der Burgt I, Crosby AH, Ion A, Jeffery S (2001): Mutations in PTPN11, encoding the protein tyrosine phosphatase SHP-2, cause Noonan syndrome. Nat Genet 29(4), 465-468.

Tartaglia M, Cordeddu V, Chang H, Shaw A, Kalidas K, Crosby A, Patton MA, Sorcini M, van der Burgt I, Jeffery S, Gelb BD (2004): Paternal germline origin and sex-ratio distortion in transmission of PTPN11 mutations in Noonan syndrome. Am J Hum Genet 75(3), 492-497.

Tellier AL, Lyonnet S, Cormier-Daire V, de Lonlay P, Abadie V, Baumann C, Bonneau D, Labrune P, Lacombe D, Le Merrer M (1996): Increased paternal age in CHARGE association. Clin Genet 50(6), 548-550.

Thompson BA, Tremblay V, Lin G, Bochar DA (2008): CHD8 is an ATP-dependent chromatin remodeling factor that regulates beta-catenin target genes. Mol Cell Biol $\underline{28}, 3894-$ 3904.

Tiemann-Boege I, Navidi W, Grewal R, Cohn D, Eskenazi B, Wyrobek AJ, Arnheim N (2002): The observed human sperm mutation frequency cannot explain the achondroplasia paternal age effect. Proc Natl Acad Sci USA 99(23), 14952-14957.

Trappe R, Laccone F, Cobilanschi J, Meins M, Huppke P, Hanefeld F, Engel W (2001): MECP2 mutations in sporadic cases of Rett syndrome are almost exclusively of paternal origin. Am J Hum Genet 68(5), 1093-1101.

Trotter KW, Archer TK (2008): The BRG1 transcriptional coregulator. Nucl Recept Signal $\underline{6}$, e004.

Van Blerkom J, Sinclair J, Davis P (1998): Mitochondrial transfer between oocytes: potential applications of mitochondrial donation and the issue of heteroplasmy. Hum Reprod $\underline{13}, 2857-2868$.

Verloes A (2005): Updated diagnostic criteria for diagnosis of CHARGE syndrome: a proposal. Am J Med Genet $\underline{133}$, 306-308. 
Vissers LE, van Ravenswaaij CM, Admiraal R, Hurst JA, de Vries BB, Janssen IM, van der Vliet WA, Huys EH, de Jong PJ, Hamel BC (2004): Mutations in a new member of the chromodomain gene family cause CHARGE syndrome. Nat Genet 36(9), 955-957.

Wahl MC, Will CL, Lührmann R (2009): Review: The Spliceosome: Design Principles of a Dynamic RNP Machine. Cell 136(4), 701-718.

Wilkin DJ, Szabo JK, Cameron R, Henderson S, Bellus GA, Mack ML, Kaitila I, Loughlin J, Munnich A, Sykes B (1998): Mutations in fibroblast growth-factor receptor 3 in sporadic cases of achondroplasia occur exclusively on the paternally derived chromosome. Am J Hum Genet $\underline{63(3)}, 711-716$.

Wincent J, Holmberg E, Strömland K, Soller M, Mirzaei L, Djureinovic T, Robinson K, Anderlid B, Schoumans J (2008): CHD 7 mutation spectrum in 28 swedish patients diagnosed with CAHRGE syndrome. Clin Genet 74(1), 31-38.

Wohllk N, Cote GJ, Bugalho MM, Ordonez N, Evans DB, Goepfert H, Khorana S, Schultz P, Richards CS, Gagel RF (1996): Relevance of RET proto-oncogene mutations in sporadic medullary thyroid carcinoma. J Clin Endocrinol Metab 81(10), 3740-3745.

Wu PY, Ruhlmann C, Winston F, Schultz P (2004): Molecular architecture of the S. cerevisiae SAGA complex. Mol Cell 15(2), 199-208.

Yates JA, Menon T, Thompson BA, Bochar DA (2010): Regulation of HOXA2 gene expression by the ATP-dependent chromatin remodeling enzyme CHD8. FEBS Letters 584(4), 689-693.

Yuan CC, Zhao X, Florens L, Swanson SK, Washburn MP, Hernandez N (2007): CHD8 associates with human Staf and contributes to efficient U6 RNA polymerase III transcription. Mol Cell Biol 27(24), 8729-8738.

Zentner GE, Layman WS, Martin DM, Scacheri PC (2010): Molecular and Phenotypic aspects of CHD7Mutation in CHARGE Syndrome. Am J Med Genet 152A, 674-686. 
